\title{
Morbidity and mortality risk of aging diabetic and psychogeriatric patients
}

\author{
Citation for published version (APA):
}

Pijpers, E. (2012). Morbidity and mortality risk of aging diabetic and psychogeriatric patients. [Doctoral Thesis, Maastricht University]. Datawyse / Universitaire Pers Maastricht. https://doi.org/10.26481/dis.20120525ep

Document status and date:

Published: 01/01/2012

DOI:

10.26481/dis.20120525ep

Document Version:

Publisher's PDF, also known as Version of record

\section{Please check the document version of this publication:}

- A submitted manuscript is the version of the article upon submission and before peer-review. There can be important differences between the submitted version and the official published version of record.

People interested in the research are advised to contact the author for the final version of the publication, or visit the DOI to the publisher's website.

- The final author version and the galley proof are versions of the publication after peer review.

- The final published version features the final layout of the paper including the volume, issue and page numbers.

Link to publication

\footnotetext{
General rights rights.

- You may freely distribute the URL identifying the publication in the public portal. please follow below link for the End User Agreement:

www.umlib.nl/taverne-license

Take down policy

If you believe that this document breaches copyright please contact us at:

repository@maastrichtuniversity.nl

providing details and we will investigate your claim.
}

Copyright and moral rights for the publications made accessible in the public portal are retained by the authors and/or other copyright owners and it is a condition of accessing publications that users recognise and abide by the legal requirements associated with these

- Users may download and print one copy of any publication from the public portal for the purpose of private study or research.

- You may not further distribute the material or use it for any profit-making activity or commercial gain

If the publication is distributed under the terms of Article $25 \mathrm{fa}$ of the Dutch Copyright Act, indicated by the "Taverne" license above, 
Morbidity and mortality risk of aging diabetic and psychogeriatric patients 
(C) Evelien Pijpers, Maastricht 2012

Layout: Tiny Wouters

Cover: Aquarel HA Pijpers 1995, afbeelding kunstenares Lanzarote

Production: Datawyse Maastricht

ISBN: 9789461591487

The printing of this thesis was financially supported by Amgen B.V., Boehringer Ingelheim, Eli Lilly Nederland BV, Menarini Farma Nederland, Novartis Pharma B.V. and Vifor Pharma. 


\title{
Morbidity and mortality risk of aging diabetic and psychogeriatric patients
}

\author{
ter verkrijging van de graad van doctor \\ aan de Universiteit Maastricht, \\ op gezag van de Rector Magnificus, \\ Prof. mr. G.P.M.F. Mols, \\ volgens het besluit van het College van Decanen, \\ in het openbaar te verdedigen \\ op vrijdag 25 mei 2012 om 14.00 uur
}

door

Evelien Pijpers

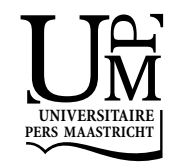




\section{Promotores}

Prof. dr. A.C. Nieuwenhuijzen Kruseman

Prof. dr. C.D.A. Stehouwer

\section{Copromotor}

Dr. I. Ferreira

\section{Beoordelingscommissie}

Prof. dr. J.M.G.A. Schols, voorzitter

Prof. dr. G.I.J.M. Kempen

Dr. S.E.J.A. de Rooij

Prof. dr. N.C. Schaper

Prof. dr. F. Verhey 
Warning

When I am an old woman I shall wear purple

With a red hat which doesn't go, and doesn't suit me.

And I shall spend my pension on brandy and summer gloves

And satin sandals, and say we've no money for butter.

I shall sit down on the pavement when I'm tired

And gobble up samples in shops and press alarm bells

And run my stick along the public railings

And make up for the sobriety of my youth.

I shall go out in my slippers in the rain

And pick flowers in other people's gardens

And learn to spit.

You can wear terrible shirts and grow more fat

And eat three pounds of sausages at a go

Or only bread and pickle for a week

And hoard pens and pencils and beermats and things in boxes.

But now we must have clothes that keep us dry

And pay our rent and not swear in the street

And set a good example for the children.

We must have friends to dinner and read the papers.

But maybe l ought to practice a little now?

So people who know me are not too shocked and surprised

When suddenly I am old, and start to wear purple.

Jenny Joseph

To all those I hold dear 



\section{Contents}

Chapter $1 \quad$ General introduction 9

Chapter $2 \quad$ Core concepts in this thesis 15

Chapter $3 \quad$ Polymorbidity in diabetes in older people; 23

consequences for care and vocational training

Chapter 4 Older individuals with diabetes have an increased risk of

recurrent falls: analysis of potential mediating factors

- The Longitudinal Ageing Study Amsterdam -

Chapter 5 Predicting mortality of psychogeriatric patients:

a simple prognostic frailty risk score

Chapter 6 The frailty dilemma.

Review of the predictive accuracy of major frailty scores

Chapter 7 General discussion

Summary

Samenvatting

Dankwoord

Curriculum vitae 



\section{Chapter 1}

General introduction 


\section{General introduction}

At present the Netherlands has approximately 16.5 million inhabitants. The number of inhabitants over the age of 65 years has risen from $13.6 \%$ in 2000 to $14.5 \%$ in 2008 . In the same period of time mortality has gone down due to progress in medical care and favourable developments in population lifestyle such as reduced smoking habits. The number of Dutch inhabitants over the age of 65 years is expected to rise to almost $24 \%$ in 2040. This percentage is estimated to amount to 4 million people. Life expectancy at birth for a boy born in 2008 is 78.4 years; a girl born in 2008 can expect to live for 82.4 years.

The age distribution of the Dutch population will therefore change considerably in the near future. In the period from 2010 to 2016 the number of inhabitants below the age of 40 years will diminish with a quarter of a million and the number of inhabitants over the age of 65 will rise with 0.6 million. This so called gray pressure, which is the number of people of 65 years and older as a percentage of the potential working population, will rise more than 6 percent. This means that, as in other countries the Dutch population is aging, both in absolute numbers and relative to the working population.

\section{Healthy life expectancy}

Healthy life expectancy is the average number of years people can expect to live in good health. Healthy life expectancy is defined firstly on the basis of life expectancy, secondly on the basis of a good self perceived health, thirdly on a lack of disabilities (or functional limitations), fourthly on the absence of chronic diseases and finally on presence of a good mental health. The challenge to physicians involved in the provision of high quality health care for an aging population is to achieve a maximal healthy life expectancy.

1. Self perceived health is defined as the individual's evaluation of his or her own health. ${ }^{1,2}$ It is closely linked to the state of health as measured by more objective indicators. ${ }^{3}$ Many authors have shown that functional health, physical disorders and mental health are all predictors of health perception in the elderly. ${ }^{4}$ The perception of health and the link with objective health measures such as the number of illnesses changes with advancing age. Older people tend to experience health beyond the purely biomedical definition and base their evaluation on attitudes such as optimism rather than functional capacity. They situate themselves in relation to certain benchmarks both social and temporal rather than in absolute terms. ${ }^{5,6}$ Therefore experiencing good health may be a subjective measure as it contains health aspects other than the presence or absence of physical health.

2. Physical disability and functional limitations. These terms are often used interchangeably. They refer to a limitation in the ability to perform an activity in a 
normal manner or to the disturbance in the performance of daily tasks like dressing or bathing. The number of people with a functional limitation increases with age from $14 \%$ of $55-60$ years old to $38 \%$ of $75-80$ years old. Most often these functional limitations concern mobility, closely followed by visual and hearing limitations. Older women are more often physically disabled than men. ( 25 versus $16 \%$ ) Social status also has an influence on the number of functional limitations. A lower income status is associated with a higher number of functional limitations. ${ }^{7}$

3. Chronic disease is a major health problem in the aging population. In the Netherlands nearly half of the population is afflicted by one chronic disease and $25 \%$ of the population suffers from 2 or more chronic conditions. The number of people with 2 or more chronic diseases increases from $25 \%$ to $46 \%$ between the age of 65 -and 75 years and even to $57 \%$ over the age of 75 years. Thus an increasing number of individuals with a chronic disease will suffer from more than one chronic disease. ${ }^{8}$ Diabetes Mellitus as an index disease with a major impact on life expectancy and healthcare has a prevalence in the Netherlands of $4.4-8.9 \%$ (in males and females respectively) at the ages of 45-64 years. This number rises to $9.6-11.3 \%$ in males and females respectively over the age of $74 .^{9}$

4. Mental health is often described as the absence of objective signs of mental disease. The prevalence of psychiatric disorders other than dementia in people over the age of 65 years is estimated to be $16 \%$. Additionally about $10 \%$ of elderly people have dementia; usually of the Alzheimer type. ${ }^{10}$ In 2008 the number of patients suffering from dementia in the Netherlands was 200.000. This number rises to 207.000 in 2010 and is expected to reach 400.000 in $2050 .{ }^{11}$ Dementia is associated with a shortened life expectancy. ${ }^{12}$ Median survival after diagnosing dementia is between 3 and 9 years. ${ }^{13}$ Mortality figures of patients with dementia admitted to long term care facilities exceed those of age matched non demented peers with a factor $3.5 .^{14,15}$ In 4 years time $46 \%$ of patients diagnosed with dementia have died, in 8 years time this figure amounts to $81 \% .^{16,17}$ The most prevalent direct cause of death of these frail elderly patients is bronchopneumonia. ${ }^{11}$

Healthy life expectancy in the Netherlands has been well documented. Health statistics based on average figures for 2007-2011 show that although Dutch women live longer than men (82.7 years versus 78.8 years), the number of years men and women in Holland can expect to live in good self perceived health is more or less equal. (63.9 years in men and 63.0 years in women). The number of years spent without disabilities ( 70.2 years in men and 69.7 years in women) and in good mental health ( 72.4 years in men and 72.7 years women) are also equal. However life expectancy without chronic diseases differs in men and women, with men experiencing 47.2 years without chronic diseases and women 40.6 years. At the age of 65 years the life expectancy for men is 18.0 years and for women 21.2 years. Healthy life expectancy at 65 years however is 11.3 years in men and 11.1 years in women. Therefore Dutch women spend more years in ill-health than men. In the Longitudinal Aging Study Amsterdam (LASA) elderly 
Dutch women were more likely to be frail than elderly Dutch men. Women characterized as frail, experienced a lower quality of health than non-frail women. ${ }^{18}$

\section{Objectives}

The Aim of this thesis is to find an answer to a number of questions concerning the aging process and the conversion of older adults with an apparently normal healthy life expectancy into frail elderly people with a reduced quality of life finally culminating in death.

The specific research questions are:

1. What is the prevalence of complicating and concurrent morbidities in older patients with diabetes mellitus?

2. To what extent does the occurrence of co morbidity affect the burden of disease in older patients with diabetes mellitus, and their use of medical healthcare?

3. Does the clustering of complicating and concurrent morbidity in diabetes patients over the age of 65 years lead to serious functional consequences such as recurrent falling?

4. Frailty and mortality in psychogeriatric patients are hard to predict but important in counseling and therapeutic decision making. Can a simple prognostic frailty risk score be developed and validated in psychogeriatric patients?

5. To identify frail elderly individuals, several index or scoring systems have been developed for research purposes. The practical value of these scores for screening and diagnostic use is uncertain. Can any of the available scoring systems be used in daily practice, for the purpose of distinguishing low- from high-risk elderly patients? In other words, are present day frailty scores sensitive and specific enough to identify frail people and hence are they of relevance yet for diagnostic and therapeutic decisions in medical care of elderly people? 


\section{Outline of this thesis}

In chapter 2 the core concepts referred to in this thesis are described. These concepts are frailty, poly-morbidity/multimorbidity, and functional limitations/disability. In this chapter we describe the interrelationship of these concepts and their association with mortality in older patients.

In chapter 3 the prevalence of complicating and concurrent morbidities in diabetic patients over the age of 60 years is described. The extent to which these morbidities determine the burden of disease in elderly diabetic patients and the resulting use of healthcare is discussed.

In chapter 4 the investigation into the risk of recurrent falling in diabetic patients over the age of 65 years compared to non diabetic patients over the age of 65 years is reported.

In chapter 5 the development of a frailty index in a group of elderly psycho-geriatric subjects in an out-patient setting is described. A risk scoring rule, based on a set of relatively simple and commonly used standardised tests for aspects of frailty, was developed to distinguish low- from high-risk elderly psycho-geriatric patients, in order to enable better tailored diagnostic and therapeutic interventions.

In chapter 6 a literature search into the sensitivity and specificity of internationally accepted frailty scores developed to identify frail elderly individuals for research purposes is presented.

In chapter 7 a general discussion of the main findings of this thesis, and the relevance and implications of the main findings for public health and current clinical practice is presented.

Also enclosed the summary of the main findings of this thesis in English and in Dutch. 


\section{References}

1. Schneider G, Driesch G, Kruse A, Wachter M, Nehen HG, Heuft G. What influences self-perception of health in the elderly? the role of objective health condition, subjective well-being and sense of coherence. Archives of Gerontology and Geriatrics. 2004;39:227-37.

2. Henchoz Karine CS, Giradin Myriam. Health perception and health status in advanced old age: a paradox of association. Journal of Aging Studies. 2008;22:282-290.

3. Pinquart $M$, Sorensen S. Gender differences in self-concept and psychological well-being in old age: a meta-analysis. J Gerontol B Psychol Sci Soc Sci. 2001;56:P195-213.

4. Krause NM, Jay GM. What do global self-rated health items measure? Med Care. 1994;32:930-42.

5. van den Akker M. BF, Knottnerus A. Comorbidity or multimorbidity: what's in a name? a review of the literature. European Journal of General Practise. 1996;2:65-70.

6. Rütten A, Abel T, Kannas L, von Lengerke T, Lüschen G, Diaz JA, Vinck J, van der Zee J. Self reported physical activity, public health, and perceived environment: results from a comparative European study. Journal of epidemiology and community Health. 2001;2:139-46.

7. Knoops K. vd Brakel M. Welgestelde mensen leven lang en gezond: Inkomensgerelateerde verschillen in gezonde levensverwachting. ISSN 1876-8776 Bohn Stafleu en v Lochum. TSG. 2010;1:17-24.

8. Menotti A, Mulder I, Nissinen A, Feskens E, Giampaoli S, Tervahauta M, Kromhout D. Cardiovascular risk factors and 10-year all-cause mortality in elderly European male populations; the FINE study.

Finland, Italy, Netherlands, Elderly. Eur Heart J. 2001;22:573-9.

9. Fleming DM, Schellevis FG, Van Casteren V. The prevalence of known diabetes in eight European countries. European Journal of Public Health. 2004:10-4.

10. Jette AM, Binstock RH, George LK, Marshall VW; Myers GC, Schulz JH. Disability trends and transitions. Handbook of aging and the social sciences.(4th ed.). San Diego, CA, US: Academic Press. 1996:94-116.

11. Meulen van der A. KDI. Sterfte aan Dementie. wwwCBSnl. 2010.

12. Rijk Cd. Psychische stoornissen: dementie. Volksgezondheid toekomstverkenning RIVM Bilthoven. 1993.

13. Gezondheidsraad. Dementie: advies van een commissie van de gezondheidsraad. 2002.

14. Lankers D, Kissler S, Hötte SD, Freyberger HJ, Schröder SG. Leben Demenzkranke zu Hause länger als im Heim? Zeitschrift für Gerontologie und Geriatrie. 2010;43:254-8.

15. Eaker ED, Vierkant RA, Mickel SF. Predictors of nursing home admission and/or death in incident Alzheimer's disease and other dementia cases compared to controls: A population-based study. Journal of Clinical Epidemiology. 2002;55:462-8.

16. Perenboom RJM, Boshuizen HC, Breteler MMB, Ott A, Van de Water HPA. Dementia-free life expectancy (DemFLE) in The Netherlands. Social Science \& Medicine. 1996;43:1703-7.

17. Jagger C, Andersen K, Breteler MMB, Copeland JRM, Helmer C, Baldereschi M, Fratiglioni L, Lobo A, Soininen H, Hofman A, Launer LJ. Prognosis with dementia in Europe: A collaborative study of population-based cohorts. Neurology. 2000;54:S16-S20.

18. Puts MT, Lips $P$, Deeg DJ. Sex differences in the risk of frailty for mortality independent of disability and chronic diseases. J Am Geriatr Soc. 2005;53:40-7. 


\section{Chapter 2}

Core concepts in this thesis 
Chapter 2 


\section{Frailty}

A consensus conference defined frailty as "a state of increased vulnerability to stressors due to age-related decline in physiologic reserve across neuromuscular, metabolic, and immune systems". ${ }^{1}$ Many operational definitions include alterations in mobility, strength, endurance, nutrition, and physical activity. ${ }^{2-5}$ The presence of cognitive impairment or social deprivation increases the likelihood of adverse health outcomes in geriatric patients who meet criteria for physical frailty ${ }^{6}$, but not all operational definitions of frailty incorporate cognitive assessment or socio economic factors. ${ }^{6,7}$

The prevalence of frailty and pre-frailty in the whole Dutch population aged 65 years and older is estimated to be $38.5 \%$ for pre-frailty and $11.3 \%$ for frailty. In the population over 65 years without disabilities or functional limitations (defined as one or more health related difficulties in the five Katz basic activities of daily living) the prevalence of pre-frailty is $37.4 \%$ and the prevalence of frailty $8.5 \%{ }^{7}$ The percentages reported increase with increasing age, to $45 \%$ over the age of 85 years. ${ }^{2,7}$ Frail individuals are at high risk for dependency, institutionalization, falls, injuries, hospitalization, slow recovery from any illness and mortality. They are therefore most in need of health care and community and informal support services.

Frailty is partly a consequence of biological changes related to the aging process and partly a consequence of the occurrence of one or more chronic conditions and their complications. Frailty, Co-morbidity, disability and functional limitations are seen as overlapping, causally related but distinct entities. (Figure 2.1 )

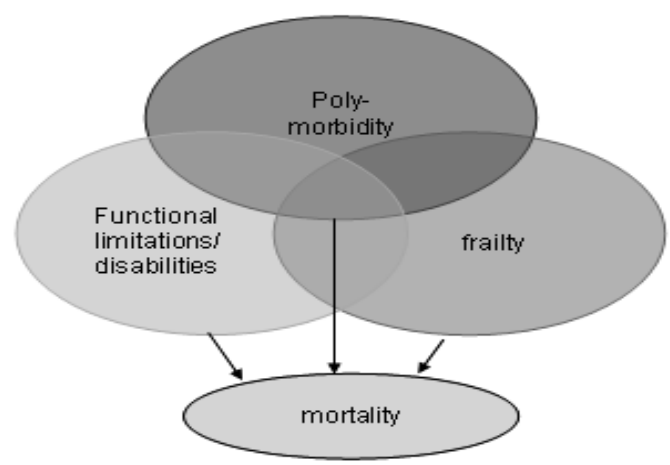

Figure 2.1 Relationship between frailty, poly-morbidity, disability/ functional limitations and mortality. 
The present models of the patho-physiology of biological changes in the development of frailty involve frailty- related changes in the skeletal muscle, endocrine and immune systems. Age-related loss of skeletal muscle and muscle strength, so-called sarcopenia, starts approximately at the age of 35 years and can progress to the point where up to $50 \%$ of lean body mass (skeletal muscle) is replaced with fibrotic and/or adipose tissue. ${ }^{8}$ The loss of muscular mass results in decreased strength and exercise tolerance, poor balance and a slower gait, impairing the ability to perform many activities of daily living and rendering the individual vulnerable to falls and injuries. The metabolic consequences of sarcopenia result in a lower resting metabolic rate and impaired thermoregulation. The replacement of lean body tissues with fat increases insulin resistance and glucose intolerance. This may contribute to a generalized catabolic state. Genetics, acute and chronic diseases, vitamin D deficiency, lack of exercise and the use of medication can also contribute to sarcopenia.

Neuro-endocrine changes occurring with age include lower levels of testosterone, estrogens, GH, IGF-1 and DHEA-S, and higher levels of cortisol. These hormones are important in the maintenance of lean body mass and bone mineral density. ${ }^{9,10}$ In combination with other physiologic changes, neuro-endocrine changes contribute to sarcopenia and the frailty syndrome.

Age-related changes in the immune system result in elevated levels of catabolic cytokines contributing to a chronic inflammatory state. ${ }^{1,11,12}$ This chronic inflammatory state may adversely affect skeletal muscle, appetite, innate immune system function, and cognition. ${ }^{13}$ The chronic conditions attributing to the development of frailty involve advanced stages of heart failure, renal impairment, stroke, osteoarthritis of hip and knee and depression in particular. ${ }^{14-16}$

Decline across the three systems (musculoskeletal-, neuro-endocrine- and immunesystems) most likely has a synergistic physiologic effect explaining the vulnerability of the individual. It is however generally accepted that frailty is a pre-disability state with the potential for intervention.

Focal point of geriatric medicine has therefore always been the identification, evaluation and treatment of (pré)-frail older adults and the prevention of functional disability, illness, loss of independence and other negative health outcomes, thereby expanding healthy life expectancy and improving quality of life. The goal of geriatric intervention is to shift from episodic interventions in response to acute medical events to an integrated multidisciplinary approach in which continuous care can be planned and conducted in close collaboration with older patients, care givers and other health professionals involved.

\section{Poly-or multimorbidity}

Poly- or multimorbidity is defined as the presence of two or more chronic or acute diseases in one person. Co-morbidity relates to additional chronic irreversible 
conditions next to, and apart from, the index disease. In complicating- (or causal-) comorbidity the additional chronic conditions are a consequence of the first chronic condition. Concurrent co-morbid conditions are chronic diseases unrelated to the index condition. Inter-current co-morbidity comprises all reversible conditions observed occurring next to the chronic index disease. Cluster co-morbidity indicates statistically significant associations between diseases without a causal explanation. ${ }^{17}$ Chronic conditions such as cardiovascular disease, pulmonary disease, diabetes mellitus, dementia, or combinations of these are associated with increased short- and long-term mortality rates and significant disability. However, a survey of people with multi-morbidity (two or more out of the categories arthritis, heart disease, stroke, diabetes, cancer, cataracts and broken hip) over the age of 70 years only yielded slightly higher rates of new confinement to bed or chair than in people without multimorbidity. (24 versus $17 \%)^{18}$ Therefore, having a number of co-morbid conditions as such does not predict loss of independence. However there is a significant trend of increasing prevalence of frailty in persons with more diseases ${ }^{14}$ and older persons with advanced stages of heart failure, renal impairment, stroke, osteoarthritis of hip and knee and depression are significantly more likely to be classified as frail than persons

without these conditions. ${ }^{16,19}$ Concluding: it is not the existence of multiple chronic conditions per se, but rather the severity and presence of complications of these conditions that is relevant to the occurrence of negative health outcomes.

\section{Functional limitations and disability}

The terms physical disability and functional limitations are used interchangeably. They refer to a limitation in the ability to perform an activity in a normal manner or the disturbance in the performance of daily tasks like dressing or bathing. In the Dutch population between 55 and 80 years old, $11 \%$ of people have one or more problems in the execution of the activities daily life, and $23 \%$ have one or more functional limitations (mostly mobility problems). ${ }^{20}$

The development of disabilities or functional impairments in older patients is generally a gradual process of decline due to multiple underlying causal factors. Even if the disability is caused by a single catastrophic event such as a stroke or hip fracture there are usually multiple co-morbid conditions present that complicate the event and subsequent rehabilitation. To facilitate understanding of the disablement process, it is often divided into four steps. The first step is the disease, (the underlying pathology or disorder) the second step is the impairment, (dysfunction at the level of organ systems) the third step is the functional limitation or disability (the dysfunction in activities of daily life) and the last step is the development of a social disability or handicap.

Disability measures such as the Assessment of Motor and Process Skills (AMPS) ${ }^{21,22}$ capture the impact of the presence and severity of multiple pathologies including 
physical, cognitive and psychological conditions as well as the combined effect of these conditions on the overall health status of the person involved. Disability is a potent health status indicator in predicting frailty and negative health outcome. However it is important to realize that this gradual disablement process is open to intervention and modification at every stage. Present geriatric practice aims at thoroughly defining the underlying disablement process and targeting specific treatments to identified conditions.

\section{Mortality}

Five leading causes of death account for $70 \%$ of all mortality over the age of 65 years world wide. These causes are: cancer, heart disease, stroke, chronic lower respiratory tract disease and Alzheimer's disease, with Alzheimer's disease rapidly rising as underlying cause of death. With age the mortality rates of all causes of death rise exponentially, with parallel increases for heart disease, cerebro-vascular disease, pneumonia and influenza. Mortality rates for cancer, lower respiratory tract infections and diabetes do not rise as dramatically with age, probably because people who contribute to these categories die at younger ages and are less represented in the oldest segment of the population. Both Alzheimer's disease and accidents (mainly falls) show a steeper mortality slope with advancing age. ${ }^{23}$ In the Netherlands similar causes of mortality and mortality slopes over the age of 65 years are found. ${ }^{24,25}$ 


\section{References}

1. Walston J, Hadley EC, Ferrucci L, Guralnik JM, Newman AB, Studenski SA, Ershler WB, Harris T, Fried LP. Research agenda for frailty in older adults: toward a better understanding of physiology and etiology: summary from the American Geriatrics Society/National Institute on Aging Research Conference on Frailty in Older Adults. J Am Geriatr Soc. 2006;54:991-1001.

2. Fried LP, Tangen CM, Walston J, Newman AB, Hirsch C, Gottdiener J, Seeman T, Tracy R, Kop WJ, Burke G, McBurnie MA; Cardiovascular Health Study Collaborative Research Group. Frailty in older adults: evidence for a phenotype. J Gerontol A Biol Sci Med Sci. 2001;56:M146-56.

3. Ferrucci L, Guralnik JM, Studenski S, Fried LP, Cutler GB, Jr., Walston JD. Designing randomized, controlled trials aimed at preventing or delaying functional decline and disability in frail, older persons: a consensus report. J Am Geriatr Soc. 2004;52:625-34.

4. Chin APMJ, Dekker JM, Feskens EJ, Schouten EG, Kromhout D. How to select a frail elderly population? A comparison of three working definitions. J Clin Epidemiol. 1999;52:1015-21.

5. Cigolle CT, Langa KM, Kabeto MU, Tian Z, Blaum CS. Geriatric conditions and disability: the Health and Retirement Study. Ann Intern Med. 2007;147:156-64.

6. Avila-Funes JA, Amieva H, Barberger-Gateau P, Le Goff M, Raoux N, Ritchie K, Carrière I, Tavernier B, Tzourio C, Gutiérrez-Robledo LM, Dartigues JF. Cognitive impairment improves the predictive validity of the phenotype of frailty for adverse health outcomes: the three-city study. J Am Geriatr Soc. 2009;57:453-61.

7. Santos-Eggimann B, Cuenoud P, Spagnoli J, Junod J. Prevalence of frailty in middle-aged and older community-dwelling Europeans living in 10 countries. J Gerontol A Biol Sci Med Sci. 2009;64:675-81.

8. Fried LP, Walston J. Frailty and Failure to Thrive. In: Hazzard WR, Blass JP, Halter JB, Ouslander JG, Tinetti ME, editors. Principles of Geriatric Medicine \& Gerontology. 5th ed. New York: McGraw-Hill Companies, Inc.; 2003:1487-502.

9. Janssen I, Heymsfield SB, Wang ZM, Ross R. Skeletal muscle mass and distribution in 468 men and women aged 18-88 yr. J Appl Physiol. 2000;89:81-8.

10. van den Beld AW, de Jong FH, Grobbee DE, Pols HA, Lamberts SW. Measures of bioavailable serum testosterone and estradiol and their relationships with muscle strength, bone density, and body composition in elderly men. J Clin Endocrinol Metab. 2000;85:3276-82.

11. Legros JJ, Meuleman EJ, Elbers JM, Geurts TB, Kaspers MJ, Bouloux PM. Oral testosterone replacement in symptomatic late-onset hypogonadism: effects on rating scales and general safety in a randomized, placebo-controlled study. Eur J Endocrinol. 2009;160:821-31.

12. Puts MT, Lips P, Deeg DJ. Static and dynamic measures of frailty predicted decline in performancebased and self-reported physical functioning. J Clin Epidemiol. 2005;58:1188-98.

13. Leng SX, Cappola AR, Andersen RE, Blackman MR, Koenig K, Blair M, Walston JD. Serum levels of insulin-like growth factor-I (IGF-I) and dehydroepiandrosterone sulfate (DHEA-S), and their relationships with serum interleukin-6, in the geriatric syndrome of frailty. Aging Clin Exp Res. 2004;16:153-7.

14. Ershler WB, Keller ET. Age-associated increased interleukin-6 gene expression, late-life diseases, and frailty. Annu Rev Med. 2000;51:245-70.

15. Fried LF, Katz R, Sarnak MJ, Shlipak MG, Chaves PH, Jenny NS, Stehman-Breen C, Gillen D, Bleyer AJ, Hirsch C, Siscovick D, Newman AB. Kidney function as a predictor of noncardiovascular mortality. J Am Soc Nephrol. 2005;16:3728-35.

16. Shlipak MG, Stehman-Breen C, Fried LF, Song X, Siscovick D, Fried LP, Psaty BM, Newman AB. The presence of frailty in elderly persons with chronic renal insufficiency. Am J Kidney Dis. 2004;43:861-7.

17. Newman AB, Gottdiener JS, Mcburnie MA, Hirsch CH, Kop WJ, Tracy R, Walston JD, Fried LP; Cardiovascular Health Study Research Group. Associations of subclinical cardiovascular disease with frailty. J Gerontol A Biol Sci Med Sci. 2001;56:M158-66.

18. Schellevis FG, van der Velden J, van de Lisdonk E, van Eijk JT, van Weel C. Comorbidity of chronic diseases in general practice. J Clin Epidemiol. 1993;46:469-73.

19. Clark LP, Dion DM, Barker WH. Taking to bed. Rapid functional decline in an independently mobile older population living in an intermediate-care facility. J Am Geriatr Soc. 1990;38:967-72. 
20. Shlipak MG, Fried LF, Stehman-Breen C, Siscovick D, Newman AB. Chronic renal insufficiency and cardiovascular events in the elderly: findings from the Cardiovascular Health Study. Am J Geriatr Cardiol. 2004;13:81-90.

21. Wingen M. OF. Bevolkingstrends, 4e kwartaal, CBS 2008. 2008.

22. Spilg EG, Martin BJ, Mitchell SL, Aitchison TC. A comparison of mobility assessments in a geriatric day hospital. Clinical Rehabilitation. 2001;15:296-300.

23. Kirkley KN, Fisher AG. Alternate forms reliability of the assessment of motor and process skills. J Outcome Meas. 1999;3:53-70.

24. Chamandy N, Wolfson C. Underlying Cause of Death in Demented and Non-Demented Elderly Canadians. Neuroepidemiology. 2005;25:75-84.

25. Meulen van der A. Duin van C, Garssen J. Bevolkingsprognose 2008-2050: veronderstellingen betreffende de sterfte. Bevolkingstrands 2009;57(1):41-53.

26. Meulen van der A. Keij-Deerenberg I. Sterfte aan Dementie. Bevolkingstrends 2003;51(3):24-28. 


\section{Chapter 3}

Polymorbidity in diabetes in older people; consequences for care and vocational training

B van Bussel, E Pijpers, I Ferreira, P Castermans, A Nieuwenhuijzen Kruseman Postgrad Med J. 2007;83:763-7 


\section{Abstract}

\section{Objectives}

To investigate the frequency of complicating and concurrent morbidities in older diabetic patients and to evaluate the extent to which the occurrence of comorbidities affects the burden of disease and use of medical health care.

\section{Study design}

Cross-sectional analyses of retrospectively obtained data on comorbidities and use of medical health care. Healthcare registration systems were used to retrieve data on 300 patients with diabetes aged $\geq 60$ years who, according to the severity of their disease and intensity of care required, were treated in a regional general practitioner (GP), a diabetes nurse specialist (DSN) or a medical specialist (MS) practice.

\section{Results}

Complicating and concurrent morbidities were frequently found irrespectively of the type of practice involved. After adjustments for differences in sex, age and glycosylated haemoglobin (HbA1c), the extent of complicating comorbidities showed sequential increases in patients managed by GP, DNS and MS (mean number of 3.6, 4.7, 6.7, respectively, $P_{\text {trend }}<0.001$ ). However, the mean number of concurrent comorbidities was similar across all three settings (2.1, 1.8 and 2.0 respectively). Both complicating and concurrent comorbidities were similarly associated with the extent of drug use $[\beta=0.49(0.40-0.58)$ and $\beta=0.57(0.52-0.72)$, respectively] and the number of consultations to specialists other than the main care giver $[\beta=1.19$ (1.15-1.24) and $\beta=1.21$ (1.14-1.28), respectively]. However, the mean number of different specialists involved in patients' care per any additional concurrent was twice as high as per any additional complicating comorbidity $[\beta=0.60(0.48-0.71)$ vs. $\beta=0.31(0.24-0.39)]$.

\section{Conclusions}

The use of healthcare facilities by older patients with diabetes is substantial, irrespective of the complexity of the disease and the kind of practise involved. The common manifestation of complicating and concurrent comorbidities and concurrent comorbidities and their varying complexity in individual patients requires a patient-oriented rather than a disease-oriented approach and vocational training programs for care givers involved that are tailored to the complexity of multiple chronic diseases. 


\section{Introduction}

Chronic diseases are becoming a major health problem in the ageing population. As single occurrence of chronic diseases in elderly people is rare, an increasing number of individuals with a chronic disease will have comorbidities. ${ }^{1}$ These comorbidities can be differentiated into complicating (i.e. comorbidities that occur as complication of an index disease) and concurrent (i.e. the co-occurrence of multiple chronic disease in one patient). ${ }^{2,3}$

Because of the multiple aspects involved in the care of persons with a chronic disease, there is a trend to manage them by multidisciplinary teams following a disease-centred or disease-management approach, in which disease-specific guidelines are applied. Although such an approach will certainly improve the management of the disease concerned, the consequence may be that concurrent comorbidities that are not part of the disease-specific protocol or the competency of the multidisciplinary management team are insufficiently addressed in the management of the patient. ${ }^{4}$ Consequently individuals with concurrent comorbidities are treated by different disease-oriented management teams. This may contribute to fragmentation of care, loss of individual responsibility of care givers involved and confusion for the patient with multiple chronic conditions.

Diabetes mellitus is at present one of the most prevalent chronic diseases. ${ }^{5}$ Patients with diabetes mellitus of longer duration often have complicating comorbidities, in particular of a cardiovascular nature. In addition, because of the age-related manifestation of multiple chronic diseases, older diabetic patients in particular often have non-diabetes related or concurrent comorbidities as well. Diabetes is therefore a good model to study the impact of complicating and/or concurrent comorbidities on the burden of disease and consequent use of health care resources. However, this has not been addressed across different care settings (i.e. general, diabetes nurse specialist and medical specialist practices). Therefore, we investigated, in an older population of diabetic patients currently receiving care in three settings articulated within a regional disease management model for diabetes care:

1. the prevalence of both complicating and concurrent comorbidities and its impact on the burden of disease;

2. the extent to which complicating and concurrent comorbidities explain the amount of medication used and the type and volume of medical care use.

\section{Methods}

\section{Study population and design}

The study population consisted of 300 patients with diabetes, receiving care at a general practice (GP), a diabetes nurse specialist (DNS) or a medical specialist (MS) 
practise ( $n=100$ per practice - see sample size considerations below). These three care settings are part of the disease management model for diabetes care implemented in the region of Maastricht (The Netherlands) and described earlier by Vrijhoef et al.. ${ }^{6}$ Briefly, based on the disease severity and the intensity of care required (defined according to national and international guidelines) ${ }^{7,8}$ and the patient's preference, diabetic patients are assigned to one of three paths: low, medium, and high intensity care. Accordingly, patients who require low intensity care are under the primary care of the general practitioner. The diabetes nurse specialist is the main caregiver of patients requiring medium intensity care, and patients requiring high intensity care remain under the prime responsibility of the medical specialist (endocrinologist). This disease management model -“diabetes care Maastricht"- was fully implemented on January $1^{\text {st }} 2003$.

Inclusion criteria used were patients aged $\geq 60$ years at January $1^{\text {st }} 2003$ and having diabetes mellitus diagnosed before that date. Enrollment in any other health care study was an exclusion criterion.

The study was design as a retrospective record review of patients' medical files (paper and electronic) and it was approved by the ethical committee of the University Hospital Maastricht.

\section{Data collection}

Patients' demographic and clinical data were collected through retrospective review and cross-check of three different health care registration systems. Firstly, the patients' medical files were reviewed. These files were selected on the basis of lists of eligible patients made available by the administrative services within each practice; a random selection of 100 patients per practice (on the basis of patients' numbers or day of birth registered on those lists) was made by a medical student who had no previous knowledge of patients' characteristics. These files were then linked, through a unique number (for those under DNS and MS care) or date of birth (for those under GP care), to the regional University Hospital computer system, where all patients are registered. Second, this hospital computer system (Mirador) was reviewed. Finally, and if available, the patient's electronic file (implemented more recently within the diabetes care Maastricht model) was cross-checked in order to confirm the data retrieved from the other 2 sources. Data on health care use could only be assessed with the use of the Mirador system.

The data collection period was 1 January of 2003 (the date the model was fully implemented) to 31 August of 2006 (closing date of the study).

\section{Glycaemic control}

Glycaemic control is one of the major objectives in the clinical management of diabetes. We have therefore recorded patients' (most recent) levels of glycosylated 
hemoglobin (HbA1c) and glucose control regimens used - that is, the use of insulin and/or oral glucose lowering and/or oral glucose-lowering drugs.

\section{Lifetime Polymorbidity}

Lifetime-encountered diseases other than diabetes were classified and arranged using the criteria of the International Statistical Classification of Disease and Related Health Problems (ICD-10). ${ }^{9}$ The total polymorbidity data were then subdivided into three groups of polymorbidities. Firstly, the concurrent comorbidities containing all chronic non-diabetes related diseases were extracted. These concurrent diseases were defined as non-reversible diseases, without a chance of total rehabilitation, and of long-term duration -for example, musculoskeletal, otolaryngology, pulmonologic, neurological and psychological diseases. Secondly, complicating comorbidities, comprising all diseases, causally related (in either direction to diabetes mellitus, were extracted. These included dyslipidemia, obesity, neuropathy, eye disease as retinopathy and cataract, nephropathy such as proteinuria in combination with loss of renal function assessed by serum creatinin and an estimated glomerular filtration rate $<60 \mathrm{ml} / \mathrm{min}$ according to the Cockroft-Gault formula, diabetic foot disease, diabetes related connective tissue disease and cardiovascular disease. Finally, complicating infectious diseases were classified as intercurrent diseases, as were all other conditions not considered to be complicating or concurrent. ${ }^{3}$

\section{Mortality risk}

To evaluate the burden of polymorbidities on the 1-year mortality risk we calculated the combined Charlson Comorbidity Index. This index includes 19 weighted categories of comorbidity selected and scored on the basis of the strength of their associations with 1-year mortality and are combined with age adding an extra point for every decade starting at 50 years of age. ${ }^{10,11}$ Diabetes, the primary (or index) disease under investigation was not included in the score. ${ }^{12}$ The overall score reflects the cumulative increased likelihood of 1-yr mortality (the higher the score the more severe the burden of comorbidity).

\section{Use of Drugs}

The data on different types of medication used was classified and organized using the Dutch Pharmaceutical Compass 2007. ${ }^{13}$ All chronic disease-related medication used at the patient's last visit to the care giver or consultation to a specialist before were counted. For purposes of analyses these data were further specified into diabetesrelated drugs. 


\section{Use of medical health care}

The use of medical health care was expressed in terms of the amount of different types of medical specialties (other than the main care giver) and volume of consultations attended over the course of the previous 3.7 years (i.e. from January $1^{\text {st }}$ 2003 until August $31^{\text {st }}$ 2006).

\section{Sample Size}

On the basis of a previously observed ${ }^{14}$ standard deviation (SD) for the main determinant (i.e. number of complicating or concurrent comorbidities) of 2.5 and an estimated SD for the main outcomes of interest (i.e. number of different medications used or number of different medical specialists consulted or number of consultations to specialists other than the main care giver) of 2.0, when alpha level was set at $5 \%$ and power at $90 \%$, a sample size of 99 subjects would be required in order to detect a meaningful effect size (i.e. a linear regression coefficient - $\beta$ ) of 0.25 (expressed in units of outcome of interest per unit increase in main determinant). ${ }^{15}$ Because we intended to investigate the associations between complicating or concurrent comorbidity on the one hand, and the outcome variables mentioned above on the other, among patients under care in three different settings, 297 (i.e. $3 \times 99$ ) subjects would be needed. We have therefore included a total of 300 subjects (100 per care setting) in the current study.

\section{Statistical analysis}

All analyses were carried out with the Statistical Package of Social Sciences, version V12.0 for Windows (SPSS Inc, Chicago, Illinois, USA). Data were first described as mean (SD) or percentage, as appropriate. Variables with skewed distribution (i.e. volume of consultations) were log-transformed to meet the normal distribution assumptions required by the data analyses techniques used for comparisons and associations purposes (see below).

Analyses of covariance (ANCOVA) were then used to compare data, adjusted for age, sex and $\mathrm{HbA1c}-$, on comorbidities, one-year mortality risk, medication and health care use between groups of patients under GP, DNS and MS care. Linear regression models were used to investigate the associations between complicating and concurrent comorbidities (mutually adjusted) on the one hand, and the use of medication, and medical health care use, on the other. Results obtained on variables that were initially log-transformed were reversed (by exponentiation) and presented in the original scale of measurement. Statistical significance was assessed at the $5 \%$ level (i.e. $P$ value $<0.05)$. 


\section{Results}

Table 3.1 summarizes the general characteristics of the whole study population and of patients under the primary care of a GP, DNS or MS practice.

No statistically significant differences in sex distribution between groups were found (despite fewer women in the DNS sub-group). Patients under GP care were older than those under DNS or MS care $[\beta=3.4$ years $(\mathrm{Cl}: 1.4$ to 5.5$), P<0.01$ and $\beta=3.8$ years (1.8 to 5.8), $P<0.001$, respectively]. Patients under $\mathrm{MS}$ care had higher $\mathrm{HbA1c}$ values than patients under GP and DNS care $[\beta=1.2 \%$ (0.9 to1.5), $P<0.001$ and $\beta=1.0 \%$ (0.7 to 1.3), $P<0.001$, respectively]. Most of these patients were receiving insulin $(87 \%$ vs. $22 \%$ and $25 \%$; $P<0.001$ ), whereas the majority of the patients under GP and DNS care were on oral glucose lowering medication only ( $66 \%$ and $72 \%$ vs. $11 \%$, respectively; $P<0.001$ ). To account for differences between groups in sex, age and HbA1c, all the following analyses were performed with adjustments for these variables.

Table 3.1 General demographic and clinical characteristics of study population.

\begin{tabular}{lcccc}
\hline Characteristics & All & \multicolumn{3}{c}{ Setting/ main care provider } \\
\cline { 3 - 5 } & & GP $(\mathrm{n}=100)$ & DNS $(\mathrm{n}=100)$ & $\mathrm{MS}(\mathrm{n}=100)$ \\
\hline Female, \% & 54 & 56 & 47 & 58 \\
Age, years & $72.3 \pm 7.4$ & $74.7 \pm 7.7$ & $71.3 \pm 7.2$ & $70.9 \pm 6.7$ \\
Type 2 diabetes, \% & 98 & 100 & 100 & 94 \\
HbA1c, \% & $7.6 \pm 1.3$ & $7.1 \pm 1.0$ & $7.3 \pm 1.1$ & $8.3 \pm 1.2$ \\
Insulin use \% & 45 & 22 & 25 & 87 \\
Oral glucose lowering medication, \% & 50 & 66 & 72 & 11 \\
\hline
\end{tabular}

GP, general practice; DNS, nurse specialist practice; MS medical specialist practice. Data are mean (SD)r or percentages.

Table 3.2 shows the sex, age and HbA1c-adjusted levels of comorbidities, burden of disease (Charlson score), medication and medical health care utilization in the whole study population and in patients across the three practices studied.

All patients had at least one comorbidity. One patient had concurrent comorbidity only (0.3\%), 60 patients (20\%) had complicating comorbidities only, whereas the remaining 239 patients (79.7\%) had comorbidities of both complicating and concurrent nature. The mean number of complicating comorbidities increased according to patients' level of required intensity of care, i.e. low (GP), medium (DNS) and high (MS). The mean number of concurrent comorbidities was similar across the three groups. The burden of polymorbidities on the 1-year mortality risk (as assessed by the Charlson Index) was increasingly larger in patients under GP, DNS and MS care. 
Table 3.2 Levels of comorbidities, mortality risk (Charlson score) and medication and medical health care utilization in the whole study population and in patients within each of the three practices studied.

\begin{tabular}{|c|c|c|c|c|c|}
\hline \multirow[t]{2}{*}{ Characteristics } & \multirow{2}{*}{$\begin{array}{c}\text { All } \\
(n=300)\end{array}$} & \multicolumn{3}{|c|}{ Setting/main care provider } & \multirow[b]{2}{*}{$\begin{array}{c}P \text {-value fo } \\
\text { trend }\end{array}$} \\
\hline & & $\begin{array}{c}\text { GP } \\
(n=100)\end{array}$ & $\begin{array}{c}\text { DNS } \\
(n=100)\end{array}$ & $\begin{array}{c}\text { MS } \\
(n=100)\end{array}$ & \\
\hline \multicolumn{6}{|c|}{ Lifetime comorbidities per person(NO) } \\
\hline Total & $7.0 \pm 0.2$ & $5.7 \pm 0.3$ & $6.5 \pm 0.3$ & $8.7 \pm 0.4$ & $<0.001$ \\
\hline Complicating & $5.0 \pm 0.2$ & $3.6 \pm 0.3$ & $4.7 \pm 0.3$ & $6.7 \pm 0.3$ & $<0.001$ \\
\hline Concurrent & $2.0 \pm 0.1$ & $2.1 \pm 0.2$ & $1.8 \pm 0.2$ & $2.0 \pm 0.2$ & 0.799 \\
\hline \multicolumn{6}{|l|}{ Mortality risk } \\
\hline Charlson Index, score & $4.5 \pm 0.1$ & $3.9 \pm 0.2$ & $4.4 \pm 0.2$ & $5.3 \pm 0.2$ & $<0.001$ \\
\hline \multicolumn{6}{|l|}{ Medication use, no. } \\
\hline Total medication & $6.6 \pm 0.2$ & $6.3 \pm 0.3$ & $6.6 \pm 0.3$ & $7.0 \pm 0.3$ & 0.125 \\
\hline Diabetes-related medication & $5.0 \pm 0.1$ & $4.6 \pm 0.2$ & $5.1 \pm 0.2$ & $5.5 \pm 0.3$ & 0.017 \\
\hline \multicolumn{6}{|c|}{ Medical health care utilization, no. } \\
\hline Specialties involved & $4.0 \pm 0.1$ & $3.3 \pm 0.2$ & $3.8 \pm 0.2$ & $4.9 \pm 0.2$ & $<0.001$ \\
\hline Consultations & $17.1 \pm 1.1$ & $9.8 \pm 1.3$ & $13.2 \pm 1.1$ & $38.4 \pm 1.1$ & $<0.001$ \\
\hline
\end{tabular}

GP, general practice; DNS, diabetes nurse specialist practice; MS medical specialist practice. Data are mean (SD); all analyses were adjusted for age, sex and HbA1c.

Drug use was similar in all groups; $87 \%$ of the patients used 4 or more drugs. The mean number of diabetes-related medication and the mean number of different specialists involved in patients' care increased gradually in patients across GP, DNS and MS diabetes care settings. However, the total volume of consultations to specialists other than the main care giver was considerably higher in patients under MS than GP or DNS care.

Table 3.3 shows the age, sex and $\mathrm{HbA1c}$ adjusted associations of both complicating and concurrent comorbidities with medication use and medical health care utilization. In the whole population, any additional complicating or concurrent comorbidity were similarly associated with a larger number of medication used [0.49 (0.40-0.58) and 0.57 (0.42-0.72), respectively] and a greater number of total consultations to specialists [1.19 (1.15-1.24) and 1.21 (1.14-1.28), respectively). The increase in the number of different types of specialists involved per any additional concurrent comorbidity was twice as high as per any additional complicating comorbidity [0.60 (0.48-0.71) vs. 0.31 (0.24-0.39), respectively]. This pattern of association was similar across the three settings of patients' care. 


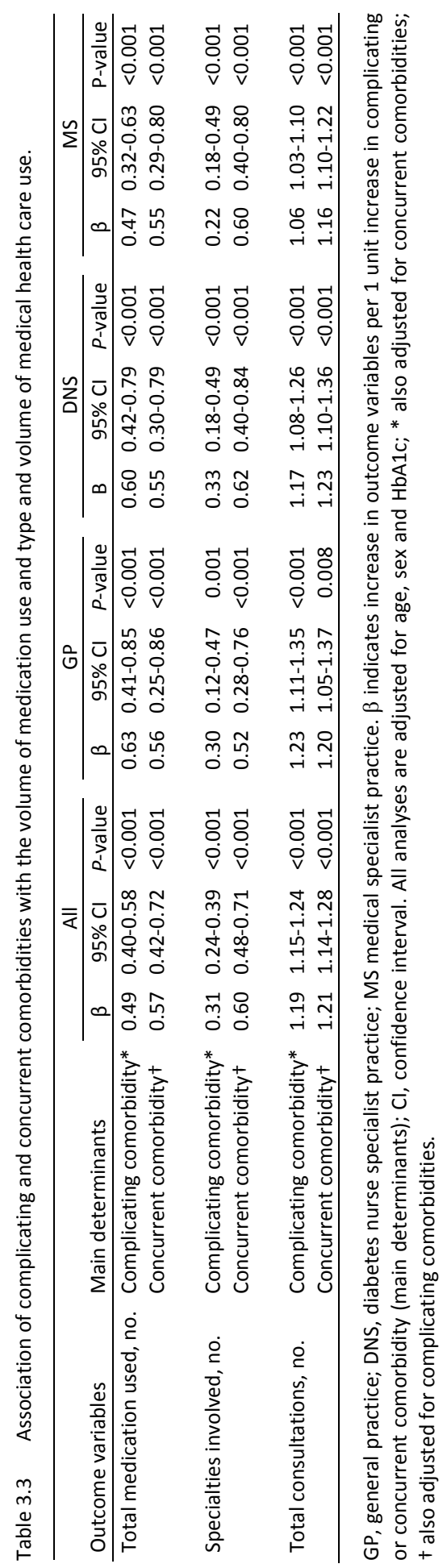




\section{Discussion}

In this study we show that complicating and concurrent comorbidities are often found in older patients with diabetes, irrespective of the type of healthcare practice involved. We found an increasing number of complicating comorbidities in patients under GP, DNS and MS care (in this order). In contrast, the extent of concurrent comorbidities was similar between patients managed across these three different settings. Patients managed by the MS, in particular, had more complications of diabetes, a higher mortality risk, more medication use, more specialties involved, more specialist consultations and worse metabolic control despite the more common use of insulin. In other words, patients managed by the MS were clearly more complex and therefore more difficult to control. This complexity should be taken into consideration when quality of care between different types of health care services are compared and when substitution of care between different types of care givers is considered. Ideally, this requires a flexible management model for the different care givers and disciplines involved. Our findings suggest that the diabetes care management model developed in our region fulfils this requirement for the most part. ${ }^{6}$

The Charlson index was used firstly to associate polymorbidity with current patient management, and secondly, to estimate the complexity of disease across settings. This index, originally developed to predict the relative mortality risk, ${ }^{10,11}$ is more than a simple count of chronic conditions in one patient: it is also of value in the assessment of the effects of polymorbidity and predicting the use of health care facilities. ${ }^{16}$ This is supported by our findings of more specialties involved and more hospital consultations by patients who were considered to have an increased mortality risk on the basis of the Charlson Index.

Most studies on the occurrence of multiple chronic diseases are performed in general practices. ${ }^{14,17,18}$ Our findings of the common occurrence of polymorbidity are in accordance with these studies, and extend the previous findings to diabetes nurse specialists and medical specialists practices. Similar observations have been found with regard to other chronic diseases such as chronic obstructive pulmonary disease, cancer and rheumatoid arthritis. ${ }^{19,20,21}$ This emphasizes the view that polymorbidity should not only be primarily a concern of general practitioners.

The findings of our study have made us question the relevance of a disease management model in the care of patients with more than one chronic disease. Several authors have discussed the conflicting relevance of multiple conditions within an individual and disease-specific guidelines. ${ }^{22,23}$ Although disease-specific guidelines are usually evidence-based, this does not mean that they are applicable in all situations. In studies on which disease-specific guidelines are based, patients with multiple conditions are usually excluded. In addition, disease-specific guidelines often do not take into consideration the simultaneous occurrence of other diseases. Therefore the value of disease-specific guidelines decreases in proportion to the increase in multiple morbidities. Polymorbidity requires an integrated patient- 
oriented rather than a fragmented disease oriented approach. Such approach is needed not only in health care services, but also in studies investigating optimal treatment strategies for patients with chronic illnesses. As at present chronic illness contributes $60 \%$ to the global burden of disease, which by the year 2020 will increase to $80 \%$, such a focus in health care research and services is of ultimate importance. ${ }^{24}$ We, like Struijs and co-workers found a substantial use of health care facilities by patients with diabetes. ${ }^{14}$ In particular in patients managed by the MS the burden of this disease in terms of hospital visits appeared to be high. These patients visited the hospital for a specialist consultation on average once a month (excluding visits for laboratory investigations and to the general practitioner). Patients managed by the GP or the DNS also showed a high use of health care facilities. The higher number of consultations for patients managed by the MS may be due, at least in part, to the higher complexity of their disease status, but are also likely due to the focus on the treatment of diabetes in this practice. To treat and manage complicating and concurrent comorbidities, consultation of other specialties is therefore often needed and prescribed. Again, this suggests that in order to better address the deleterious consequences of multiple morbidities a more holistic approach in practices for the treatment of chronic diseases may be warranted. Such an approach will therefore require that the care giver or management team is able to cover the various aspects of multiple concomitant diseases. ${ }^{25,26}$ This implies that vocational training programs of care givers, working in both general and specialist practices, should focus on these requirements. ${ }^{27}$ For specialist training programs this is far from the present situation, as these focus more and more on subspecialist expertise at the cost of general expertise, partly because of preference of trainees to become a subspecialist rather than a general physician. ${ }^{28}$

There are limitations to our study (intrinsic to its retrospective design) that warrant a mention. The validity of the data obtained rely on the accuracy with which patients' medical files were recorded by their main care givers, throughout the whole period of interest. We therefore can not exclude the possibility that some bias - for example underestimation of complicating or concurrent diseases- may have occurred. However, review of medical charts as described here is thought to yield more complete and accurate data than other methods, such as interviews or questionnaires. ${ }^{29}$ The present findings are for patients under the disease management model implemented in the region of Maastricht and inferences to other models should be made with caution. Finally, the current findings do not allow us to draw conclusions in terms of causality, but may be relevant for the generation of hypothesis in future (prospective) studies.

\section{Conclusions}

We found that the use of healthcare facilities by older patients with diabetes is substantial, irrespective of the complexity of the disease and the kind of practice involved. Therefore, we believe that the frequent manifestation of concurrent 
comorbidities in such patients requires a patient-oriented rather than a diseaseoriented approach and vocational training programs for care givers involved that are tailored to the complexity of multiple chronic diseases. 


\section{References}

1. Menotti A, Mulder I, Nissinen A, Giampaoli S, Feskens EJ, Kromhout D. Prevalence of morbidity and multimorbidity in elderly male populations and their impact on 10-year all-cause mortality: The FINE study (Finland, Italy, Netherlands, Elderly). J Clin Epidemiol 2001;54:680-6.

2. Van den Akker M, Buntinx F, Knottnerus JA. Comorbidity or multimorbidity: what's in a name? A review of literature. Eur J Gen Pract 1996;2:65-70.

3. van Weel C, Schellevis FG. Comorbidity and guidelines: conflicting interests. Lancet 2006;367:550-1.

4. Weingarten SR, Henning JM, Badamgarav E, Knight K, Hasselblad V, Gano A Jr, Ofman JJ. Interventions used in disease management programmes for patients with chronic illness-which ones work? Metaanalysis of published reports. BMJ 2002;325:925.

5. Centers for Disease Control and Prevention. The National Center for Chronic Disease Prevention and Health Promotion (NCCDPHP). Available at: http://www.cdc.gov/nccdphp/overview.htm (accessed 18 Sept 2007).

6. Vrijhoef HJ, Spreeuwenberg C, Eijkelberg IM, Wolffenbuttel BH, van Merode GG. Adoption of disease management model for diabetes in region of Maastricht. BMJ 2001;323:983-5.

7. American Diabetes Association (ADA). Clinical practice guidelines 2003. Diabetes Care 2003;26(Suppl 1):S1-S156.

8. Rutten GE, De Grauw WJ, Nijpels G, Goudswaard AN, Uitewaal PJ, Van der Does FE, Heine RJ, Van Ballegooie E, Verduijn MM, Bouma M. NHG-Standaard Diabetes mellitus type 2 (Tweede herziening). Huisarts Wet 2006;49:137-52

9. WHO. International statistical classification of diseases and related health problems. Tenth revision. 2nd edition. Geneva: World Health Organization 2005.

10. Charlson M, Pompei P, Ales KL, MacKenzie CR. A new method of classifying prognostic comorbidity in longitudinal studies: development and validation. J Chron Dis 1987; 40:373-83.

11. Charlson M, Szatrowski TP, Peterson J, Gold J. Validation of a combined comorbidity index. J Clin Epidemiol 1994;47:1245-51.

12. Extermann M. Measuring comorbidity in older cancer patients. Eur J Cancer 2000;36:453-71.

13. College voor Zorgverzekering. Farmacotherapeutisch Kompas. Available at: http://www.fk.cvz.nl (accessed 10 July 2007)

14. Struijs JN, Baan CA, Schellevis FG, Westert GP, van den Bos GA. Comorbidity in patients with diabetes mellitus: impact on medical health care utilization. BMC Health Serv Res 2006;6:84.

15. Dupont WD, Plummer WD. Power and sample size calculations for studies involving linear regression. Controlled Clin Trials 1998;19:589-601

16. Fortin M, Hudon C, Dubois MF, Almirall J, Lapointe L, Soubhi H. Comparative assessment of three different indices of multimorbidity for studies on health-related quality of life. Health Qual Life Outcomes 2005;3:74.

17. Schellevis FG, van der Velden J, van der Lisdonk E, vd Velden J, van Weel C. Comorbidity of chronic diseases in general practice. J Clin Epidemiol 1993;46:469-73.

18. Saltman DC, Sayer GP, Whicker SD. Co-morbidity in general practice. Postgrad Med J 2005;81:474-80.

19. Adams RJ, Wilson DH, Taylor AW, Daly A, Tursan d'Espaignet E, Dal Grande E, Ruffin RE. Coexistent chronic conditions and asthma quality of life: a population based study. Chest 2006;129:285-91.

20. Extermann M. Interaction between comorbidity and cancer. Cancer Control 2007;14:13-22.

21. Kahn KL, MacLean CH, Liu H, Rubenstein LZ, Wong AL, Harker JO, Chen WP, Fitzpatrick DM, Bulpitt KJ, Traina SB, Mittman BS, Hahn BH, Paulus HE. The complexity of care for patients with rheumatoid arthritis; metrics for better understanding chronic disease care. Med Care 2007;45:55-65.

22. Tinetti ME, Bogardus ST, Agostini JV. Potential pitfalls of disease-specific guidelines for patients with multiple conditions. N Eng J Med 2004;351:2870-4.

23. Boyd CM, Darer J, Boult C, Fried LP, Boult L, Wu AW. Clinical practice guidelines and quality of care for older patients with multiple comorbid diseases. JAMA 2005;294:716-24.

24. Battersby MW. Health reform through coordinated care: SA HealthPlus. BMJ 2005;330:662-5.

25. Wagner $\mathrm{EH}$. The role of patient care teams in chronic disease management. BMJ 2000;320:569-72.

26. Groves T, Wagner EH. High quality care for people with chronic diseases. BMJ 2005;330:609-10. 
27. Arora V, Guardiano S, Donaldson D, Storch I, Hemstreet P. Closing the gap between internal medicine training and practice: recommendations from recent graduates. Am J Med 2005;118:680-5.

28. Garibaldi RA, Popkave C, Bylsma W. Career plans for trainees in internal medicine residency programs. Acad Med 2005;80:507-12.

29. de Groot V, Beckerman H, Lankhorts GJ, Bouter LM. How to measure comorbidity. A review of available methods. J Clin Epidemiol 2003;56:221-9. 


\section{Chapter 4}

Older individuals with diabetes have an increased risk of recurrent falls: analysis of potential mediating factors - The Longitudinal Ageing Study Amsterdam -

E Pijpers, I Ferreira, RT De Jongh, DJ Deeg, P Lips, CDA Stehouwer, AC Nieuwenhuijzen Kruseman

Accepted Age and Ageing 2011; 0: 1-8 


\section{Abstract}

\section{Objectives}

To compare the incidence of recurrent falls in older people with and without diabetes, and to examine diabetes- and fall-related risk factors explaining the increased risk of recurrent falls associated with diabetes.

\section{Methods}

This was a Population-based cohort study of 1,145 (85 with diabetes) community-dwelling participants, aged $\geq 65$ years, from The Longitudinal Aging Study Amsterdam (LASA). Falls were assessed prospectively (every 3 months) during a 3-year follow-up period. Incidence of recurrent falls was estimated with Poisson regression analyses. The associations between diabetes and time to recurrent falls, defined as at least 2 falls occurring within a 6-month period, and the potential explanatory role of several risk factors herein, were analysed with the use of Coxregression models.

\section{Results}

During a mean follow-up of 139 weeks, $30.6 \%$ of the individuals with and $19.4 \%$ of the individuals without diabetes fell recurrently [incidence rate of 129.7 vs. 77.4 per 1,000 personsyears, respectively, $\mathrm{HR}=1.67(95 \% \mathrm{Cl}: 1.11-2.51)$ ]. Adjustments for potential confounders did not change the increased risk associated with diabetes [HR=1.63 (1.06-2.52)]. Factors that partly explained this increased risk were: greater number of medication, higher levels of pain, poorer self-perceived health, lower physical activity and grip strength, more limitations in ADLs, lowerextremity physical performance and cognitive impairment. Altogether, these variables accounted for $\sim 47 \%$ of the increased risk of recurrent falls associated with diabetes [adjusted $\mathrm{HR}=1.30(0.79-2.11)]$.

\section{Conclusions}

Fall prevention efforts targeting the factors identified above may need to be incorporated into the care and treatment of older individuals with diabetes. 


\section{Introduction}

About one third of community-dwelling adults aged 65 and older fall each year, with approximately one in ten falls resulting in a serious soft tissue injury, traumatic brain injury or fracture. ${ }^{1}$ Even if non-injurious, falls carry serious consequences including decreases in social and physical activities, physical decline, disability, loss of independence and institutionalization. ${ }^{2,3}$ Several studies have shown that older adults with diabetes fall more often than their peers without diabetes. ${ }^{4-9}$. The prevalence of diabetes increases with age, and projections for the coming decades emphasize an increase in diabetes prevalence in particular in people $>65$ years of age. ${ }^{10,11}$ The expected increase in diabetes-related falls among older adults will likely impose a significant burden on health-care systems. Therefore, investigating the extent to which older individuals with diabetes have higher incidence of falls, and identification of diabetes- and falls-related factors amenable for intervention is of utmost importance.

So far, only two prospective studies, confined to women, have compared the incidence of falls among older individuals with and without diabetes, and in both the incidence of falls, particularly recurrent falls, was significantly higher particularly among women who were treated with insulin. ${ }^{6,7}$ A recent large population-based study of individuals with diabetes showed, however, that polypharmacy was associated with greater risk of incident falls. $^{12}$ In addition, and apart from the well-known cardiovascular complications, diabetes is associated with several 'geriatric syndromes' such as cognitive decline and dementia, depression, loss of muscle strength, functional limitations and physical disabilities, visual and hearing impairments, urinary incontinence, and chronic pain. ${ }^{13,14}$ All of these are determinants of falls among community-dwelling older individuals $s^{1,15}$ and are thus likely to explain the excess risk of falls in individuals with diabetes. ${ }^{16}$ Other potential factors that may be involved include inflammatory and hormonal changes ${ }^{13}$, but their role in diabetes-related falls has never been investigated before.

We have therefore investigated, with a prospective-study design: first, the extent to which the risk of recurrent falls is higher in older community-dwelling subjects with diabetes relative to those without; and second, which diabetes and fall-related risk factors could explain such an increased risk.

\section{Methods}

\section{Study sample and design}

The Longitudinal Aging Study Amsterdam (LASA) is an ongoing interdisciplinary cohort study on predictors and consequences of changes in physical, cognitive, emotional, and social functioning in the ageing population of The Netherlands. ${ }^{17}$ For the present study, the baseline study sample consisted of participants who completed both the 
main and medical interviews during LASA's $2^{\text {nd }}$ cycle of examinations and who were $\geq 65$ years-old as per January $1^{\text {st }} 1996$ ( $n=1509$ from 1720 eligible). These individuals were invited to participate in a 3-year fall and fracture follow-up study, but 82 did not participate ( 57 refused, 12 died and 13 became severely ill and thus ineligible before the start of follow-up). We further excluded 364 participants from the analyses: those who were not living independently in the community $(n=88)$ and/or who reported having had $\geq 2$ falls during the previous year $(n=230)$. Therefore, the current study population consisted of 1145 individuals (see further details and Flow-chart illustrating the study design and sample selection in the Supplementary data available in Age and Ageing online - Appendix 4.1).

Informed consent was obtained from all participants and the study was approved by the Medical Ethics Committee of the VU University Medical Center, Amsterdam.

\section{Ascertainment of diabetes}

Presence of diabetes mellitus (type 1 or 2, not specified) at baseline was defined with an algorithm combining 3 sources of information. First, the participants were assigned the diagnosis of diabetes $(n=64)$ when such diagnosis was present in General Practitioners (GP)' records. Second, a diagnosis of diabetes was assigned to participants whose GP's records could not be retrieved ( $27 \%$ of the study population), if they self-reported diabetes and use of glucose-lowering medication was confirmed by a trained interviewer during the baseline medical interview $(n=21)$.

\section{Ascertainment of (recurrent) falls}

Falls, were prospectively assessed during 3 years using a fall calendar. ${ }^{18,19} \mathrm{~A}$ fall was defined as 'an unintentional change in position resulting in coming to rest at a lower level or on the ground ${ }^{20}$ Participants were asked to tick every week whether or not they had fallen. Once every 3 months, the calendar page was mailed to the Research Institute. If the calendar page was not received (even after a reminder), or if the page was completed incorrectly, the participants (or proxies if participants were unable to respond) were contacted by telephone.

Participants were categorized as recurrent fallers if they fell at least twice within a 6month period ${ }^{18,19}$ and as an occasional faller if they fell at least once during follow-up, but did not meet the criteria for recurrent falls. ${ }^{19}$ Distinction between occasional and recurrent falls was made deliberately to discern falls likely to have been coincidental from those more likely related to intrinsic disease-related causes. ${ }^{3,21}$ Time from baseline (date of medical interview) to the date of the $1^{\text {st }}$ (occasional) fall and to the date of the $1^{\text {st }}$ recurrent fall were recorded in week. Subjects who did not report (recurrent) falls during follow-up were censored. Time to censor was: the study maximal duration (156 weeks) among participants who completed all falls calendar sheets; or time to first missed calendar sheet (due to reasons such as death, too ill or 
refusal to continue follow-up) among those who did not complete and were thus coded as lost to follow-up (13\% of study participants).

\section{Potential confounders / mediators}

Listed in Table 4.1 (see detailed description in Supplementary data available in Age and Ageing online-Appendix 4.1).

Table 4.1 Baseline characteristics of study's participants stratified by diabetes or recurrent falls status $(n=1145)$.

\begin{tabular}{|c|c|c|c|c|c|}
\hline \multirow[t]{2}{*}{ Characteristics } & \multirow{2}{*}{$\begin{array}{c}\text { Missing } \\
\text { obser- } \\
\text { vations }\end{array}$} & \multicolumn{2}{|c|}{ Diabetes Status } & \multicolumn{2}{|c|}{$\begin{array}{c}\text { Recurrent falling during follow- } \\
\text { up }\end{array}$} \\
\hline & & No $(n=1060)$ & Yes $(n=85)$ & No $(n=913)$ & Yes $(n=232)$ \\
\hline \multicolumn{6}{|l|}{ Potential Confounders } \\
\hline \multicolumn{6}{|l|}{ Socio-demographic \& home characteristics } \\
\hline Sex, \% women & - & 49.3 & 56.5 & 49.4 & 51.7 \\
\hline Age, years & - & $75.4 \pm 6.5$ & $77.2 \pm 6.6^{*}$ & $75.2 \pm 6.4$ & $76.9 \pm 6.9 \ddagger$ \\
\hline Education level [Low ( $\leq 6$ yrs)/Medium (7-10 & - & $41.0 / 30.3 / 28.7$ & $45.9 / 30.6 / 23.54$ & $41.7 / 31.1 / 27.2$ & $40.1 / 27.2 / 32.7$ \\
\hline \multicolumn{6}{|l|}{ yrs)/High ( $\geq 11$ yrs)], \% } \\
\hline \multicolumn{6}{|l|}{ Level of urbanization } \\
\hline$<500 / 500$ to $1000 / 1000$ to $1500 / 1500$ to & 1 & 22.3/20.9/13.9/ & $/ 21.2 / 25.9 / 20.02$ & $23.1 / 21.3 / 13.5 /$ & 18.5/21.1/17.7/ \\
\hline $2500 />2500$ no. addresses $/ \mathrm{km}^{2}, \%$ & & $18.9 / 24.1$ & $/ 12.9 / 20.0$ & $18.6 / 23.5$ & $17.7 / 25.0$ \\
\hline Pets (cats and/or dogs) in household, \% & - & 16.6 & 16.5 & 15.9 & 19.4 \\
\hline Special adjustments in house, $\%$ & 2 & 27.2 & 32.9 & 26.1 & $33.6^{*}$ \\
\hline \multicolumn{6}{|l|}{ Lifestyle risk factors } \\
\hline Alcohol drinkers, \% & 1 & 76.2 & 68.2 & 75.0 & 77.9 \\
\hline Current smoker, \% & 1 & 18.5 & 18.8 & 18.8 & 17.3 \\
\hline Body mass index, $\mathrm{kg} / \mathrm{m}^{2}$ & 13 & $26.9 \pm 4.3$ & $27.9 \pm 4.2^{*}$ & $27.1 \pm 4.4$ & $26.4 \pm 3.9^{*}$ \\
\hline \multicolumn{6}{|l|}{ Potential Mediators } \\
\hline \multicolumn{6}{|l|}{ Co-morbidities and medication } \\
\hline Cardiovascular diseases, \% & 1 & 34.3 & 36.5 & 33.8 & 36.8 \\
\hline Cancer, \% & 1 & 12.0 & 11.8 & 12.4 & 10.4 \\
\hline Chronic Obstructive Pulmonary Disease/ & 1 & 14.8 & 11.8 & 15.1 & 12.6 \\
\hline \multicolumn{6}{|l|}{ Asthma, $\%$} \\
\hline Arthritis (rheumatoid/osteoarthritis), \% & 1 & 43.5 & 49.4 & 42.3 & $50.6^{*}$ \\
\hline Chronic diseases (excluding DM), no. & 1 & $1[0-2]$ & $1[0-2]$ & $1[0-2]$ & $1[1-2]$ \\
\hline Psychotropic drugs, \% & 1 & 14.4 & 20.0 & 12.7 & $23.4 \ddagger$ \\
\hline Blood pressure-lowering drugs, $\%$ & 1 & 31.8 & $48.2^{+}$ & 33.6 & 30.7 \\
\hline Lipid-lowering drugs, \% & 1 & 4.6 & 4.7 & 5.0 & 3.0 \\
\hline Glucose-lowering drugs, $\%$ & 1 & - & 88.2 & 5.7 & $10.0^{*}$ \\
\hline Insulin,/Oral/Both, \% & 1 & - & $40.0 / 67.1 / 14.1$ & $2.6 / 4.5 / 1.1$ & $4.3 / 6.9 / 0.9$ \\
\hline Medicines, no. & 1 & $2[0-3]$ & $3[2-5] \ddagger$ & $2[0-3]$ & $2[1-4]^{*}$ \\
\hline Polypharmacy ( $\geq 4$ drugs), \% & 1 & 22.7 & $48.2 \ddagger$ & 23.2 & $29.9 *$ \\
\hline \multicolumn{6}{|l|}{ Physical impairment \& general health } \\
\hline Orthostatic hypotension, \% & 46 & 34.4 & 41.0 & 33.9 & 38.5 \\
\hline Regular dizziness, \% & 3 & 13.6 & 15.5 & 12.2 & $20.9 \ddagger$ \\
\hline Foot problems, \% & 2 & 27.3 & 22.4 & 26.6 & 28.1 \\
\hline Incontinence, \% & 1 & 21.7 & 28.2 & 20.7 & $28.1^{*}$ \\
\hline Visual impairment (Poor/Insufficient/Good), \% & 1 & $15.9 / 25.7 / 59.6$ & $21.2 / 24.7 / 54.11$ & $14.8 / 25.1 / 60.12$ & $22.1 / 27.7 / 50.2+$ \\
\hline Hearing impairment (Poor/Insufficient/Good), \% & 2 & $10.3 / 7.7 / 82.0$ & $20.0 / 8.2 / 71.8^{+}$ & $10.3 / 7.3 / 82.4$ & 13.9/9.1/77.0 \\
\hline
\end{tabular}


Table 4.1 continued

\begin{tabular}{|c|c|c|c|c|c|}
\hline \multirow[t]{2}{*}{ Characteristics } & \multirow{2}{*}{$\begin{array}{l}\text { Missing } \\
\text { obser- } \\
\text { vations }\end{array}$} & \multicolumn{2}{|c|}{ Diabetes Status } & \multicolumn{2}{|c|}{$\begin{array}{l}\text { Recurrent falling during } \\
\text { follow-up }\end{array}$} \\
\hline & & No $(n=1060)$ & Yes $(n=85)$ & No $(n=913)$ & Yes $(n=232)$ \\
\hline Subjective body pain score [range $0-6$ ] & 94 & $0[0-2]$ & $1[0-2]^{\dagger}$ & $0[0-1]$ & $1[0-1] \ddagger$ \\
\hline Any pain, \% & & 31.9 & $46.2+$ & 31.4 & $38.8^{*}$ \\
\hline Self-rated health [range 1-5] ${ }^{a}$ & 1 & $2[2-3]$ & $3[2-3] \neq$ & $2[2-3]$ & $3[2-3]^{*}$ \\
\hline Hospital admission past 6 months, $\%$ & - & 8.9 & 12.9 & 8.0 & $13.8^{+}$ \\
\hline Occasional fall in previous year, $\%$ & - & 19.8 & 17.6 & 16.9 & $30.6 \ddagger$ \\
\hline \multicolumn{6}{|l|}{ Activity, Muscle Strength and Mobility } \\
\hline Physical activity, $\mathrm{min} / \mathrm{d}$ & 41 & $130[76-201]$ & $122[30-180]^{*}$ & 134 [75-203] & $118[70-181]^{*}$ \\
\hline Grip strength, kg & 48 & $57.5 \pm 20.4$ & $50.3 \pm 19.7^{\dagger}$ & $57.9 \pm 19.9$ & $53.1 \pm 22.1 \dagger$ \\
\hline \multicolumn{5}{|l|}{ (ADLs) [range 0-6] } & $1[0-3]^{\dagger}$ \\
\hline Physical performance [range $0-12]^{b}$ & 43 & $8[6-10]$ & $6[2-9] \ddagger$ & $8[6-10]$ & $7[4-9] \ddagger$ \\
\hline \multicolumn{6}{|l|}{ Psychosocial functioning } \\
\hline Cognitive impairment score (Mini-Mental Scale & 3 & 28 [26-29] & $27[24-28]^{\dagger}$ & 28 [26-29] & 27 [25-29] \\
\hline \multicolumn{6}{|l|}{ Examination, MMSE) [range 0-30] } \\
\hline MMSE $\leq 23, \%$ & & 10.7 & $21.4^{+}$ & 10.6 & 14.7 \\
\hline Depression score (Center for Epidemiological & 30 & $6[2-11]$ & $6[4-11]$ & $5[2-10]$ & $8[3-13] \ddagger$ \\
\hline \multicolumn{6}{|l|}{ Studies Depression Scale - CES-D) [range 0-60] } \\
\hline CES-D $\geq 16, \%$ & & 14.5 & 8.4 & 13.5 & 16.5 \\
\hline Fear of falling [range 0-30] & 6 & $1[0-3]$ & $1[0-4]$ & $0[0-3]$ & $1[0-3] \ddagger$ \\
\hline Loneliness [range 0-11] & 3 & $2[0-4]$ & $2[0-4]$ & $1[0-3]$ & $2[0-4]^{+}$ \\
\hline Living alone, $\%$ & - & 37.5 & $49.4^{*}$ & 37.3 & 42.2 \\
\hline \multicolumn{6}{|l|}{ Biomarkers } \\
\hline 25-hydroxyvitamin D, nmol/l & 111 & $55.4 \pm 24.0$ & $48.4 .5 \pm 20.2^{*}$ & $54.7 \pm 23.3$ & $55.7 \pm 25.6$ \\
\hline \multirow[t]{2}{*}{ Sex hormone binding globulin, $\mathrm{nmol} / \mathrm{l}$} & 110 & 43.8 & 41.3 & 42.5 & 46.3 \\
\hline & & [32.5-58.7] & {$[27.0-55.7]$} & [31.4-57.9] & {$[34.4-60.6]^{*}$} \\
\hline Insulin-like growth factor-1, $\mathrm{nmol} / \mathrm{I}$ & 112 & $14.0 \pm 5.2$ & $13.5 \pm 5.9$ & $14.0 \pm 5.3$ & $13.5 \pm 5.2$ \\
\hline Osteocalcin, nmol/l & 112 & $2.2 \pm 1.1$ & $2.1 \pm 1.1$ & $2.1 \pm 1.1$ & $2.2 \pm 1.1$ \\
\hline Parathyroid hormone, pmol/l & 111 & $3.1[2.4-4.2]$ & $3.3[2.4-4.4]$ & $3.1[2.4-4.2]$ & $3.1[2.4-4.1]$ \\
\hline Interleukin-6, pg/ml & 135 & $1.9[1.1-3.1]$ & $1.9[1.4-3.3]$ & $1.9[1.1-3.1]$ & $1.8[0.9-3.1]$ \\
\hline C-reactive protein, $\mathrm{mg} / \mathrm{l}$ & 134 & $2.9[1.4-6.4]$ & $4.0[2.5-8.2]^{\dagger}$ & $3.2[1.5-6.8]$ & $2.8[1.2-5.9]$ \\
\hline Albumin, $\mathrm{g} / \mathrm{l}$ & 109 & $44.5 \pm 2.7$ & $44.3 \pm 2.8$ & $44.6 \pm 2.8$ & $44.3 \pm 2.6$ \\
\hline Creatinine, $\mu \mathrm{mol} / \mathrm{l}$ & 108 & 90 [79-103] & 89 [81-108] & 90 [79-103] & $93[80-106]$ \\
\hline Glomerular filtration rate, $\mathrm{ml} / \mathrm{min}$ per $1.73 \mathrm{~m}^{2}$ & 108 & $58.0 \pm 11.9$ & $56.2 \pm 12.5$ & $58.2 \pm 12.0$ & $56.6 \pm 11.9$ \\
\hline
\end{tabular}

Data are mean \pm standard deviation, median [interquartile range] or frequency (\%); Higher scores indicate: a poorer self-rated health; ${ }^{b}$ better performance; ${ }^{c}$ more fear $* P<0.05 ;+P<0.01 ; \ddagger P<0.001$.

\section{Statistical analyses}

Incidence rates of recurrent falls were estimated with Poisson regression analyses. Kaplan-Meier curves were created to illustrate and compare, with log-rank tests, the cumulative incidence of recurrent falls between participants with vs. without diabetes. Baseline characteristics were compared between participants with and without diabetes and between recurrent and non-recurrent fallers with Student's T-tests, Mann-Whitney $U$ Tests, and $\chi^{2}$-tests.

We used multiple imputation by chained equations to impute missing data on study covariates $(2.5 \%$ of all required values), to boost power and enable more efficient 
analyses $^{22}$ (for details see Supplementary data available in Age and Ageing online Appendix 4.1).

Cox-proportional hazard regression models were used to account for the effects of confounders and potential mediators in the associations between diabetes and incident recurrent falls. After a first unadjusted analysis (model 1), successive models were created to examine: first, the extent to which this association was confounded by as age, sex, other socio-demographic factors, BMI, smoking, alcohol consumption (model 2); and second, explore potential pathways that may explain the association (subsequent models). Potential mediators were retained in the models if the strength of the regression coefficient $(\mathrm{Ln}-\mathrm{HR})$ reflecting the association between diabetes and recurrent falls was attenuated by $\geq 5 \%$.

All analyses were carried out with Predictive Analytics SoftWare (PASW) Statistics software version 18.0 (SPSS Inc, Chicago, IL, USA).

\section{Results}

Comparisons of participants' characteristics at baseline according to their diabetes or recurrent falls status are shown in Table 4.1. Eighty-five participants (7.4\%) had an adjudicated diagnosis of diabetes (6.4\% in men and $8.4 \%$ in women, $P=0.201)$. During a mean follow-up duration of 139 weeks, 232 participants (20.3\%) fell recurrently. Nonrecurrent fallers $(n=913)$ included 366 individuals who were classified as 'occasional fallers', but the incidence of occasional falls did not significantly differ by diabetes status $(30.5 \%$ vs. $40.7 \%, P=0.132)$. In contrast, the incidence of recurrent falls was greater among individuals with than without diabetes (30.6\% vs. $19.4 \%, P=0.017)$. The incidence rate of recurrent falls (per 1,000 persons-years) was 129.7 and 77.4 for individuals with and without diabetes, respectively: incidence rate ratio $($ IRR $)=1.67$ (95\% Cl: 1.11-2.51) (Figure 4.1). These estimates did not differ between individuals with diabetes who were or not treated with insulin [122.2 vs. 134.8, respectively, IRR=0.91 (0.41-2.00)].

The risk for recurrent falls remained higher among individuals with diabetes even after adjustments for potential confounders: $H R=1.63$ (1.06-2.52), (Table 4.2, model 2). These estimates were slightly higher in women $[H R=1.82(1.06-3.13)]$ than in men [HR=1.41 (0.73-2.72)], albeit not significantly so ( $p$-interaction=0.577). Also, age did not modify the association between diabetes and incident falls ( $p$-interaction $=0.662$ ). Factors that explained, in part, the increased incidence of recurrent falls associated with diabetes were: the greater number of medicines used; higher levels of body pain; poorer self-perceived health; lower levels of physical activity and grip strength; more limitations in ADLs; lower physical performance (including gait and balance), and cognitive impairment (models $3-6$ ). Altogether, these variables accounted for $\sim 47 \%$ of the increased risk associated with diabetes (model 7).

For additional information on the lack of a mediating role of the other variables examined, and the lack of impact of loss to follow-up on the estimates and inferences 
arising from our analyses please see Supplementary data available in Age and Ageing online-Appendix 4.2).

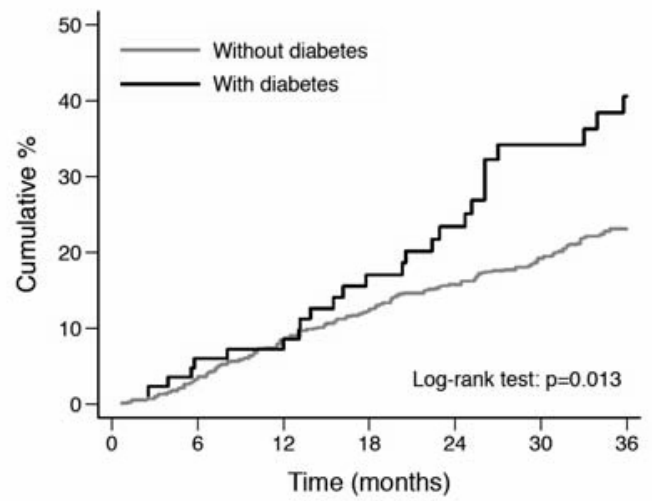

Number at risk (events)

Without diabetes 1060 (32) 1022 (48) 938 (38) 880 (31) 828 (24) 786 (33) 720 With diabetes 85 (4) 81 (2) 78 (6) 66 (5) 60 (6) 50 (3) 46

Figure 4.1 Kaplan-Meier curves for recurrent falls during 3-years of follow-up by diabetes status.

Table 4.2 Associations between diabetes and incident risk of recurrent falls and the role of selected mediators herein.

\begin{tabular}{|c|c|c|c|c|c|c|}
\hline Model & Adjustments & $\mathrm{HR}$ & $95 \% \mathrm{Cl}$ & $P$-value & $\begin{array}{c}\text { Coefficient } \\
\text { (Ln-HR) }\end{array}$ & $\begin{array}{c}\text { Change in } \\
\text { Coefficient vs. } \\
\text { model } 2(\%)\end{array}$ \\
\hline 1 & None & 1.67 & $1.11-2.51$ & 0.014 & & \\
\hline \multirow[t]{2}{*}{2} & Model $1+$ potential confounders & & & & - & - \\
\hline & $\begin{array}{l}\text { Age, sex, education level, level of } \\
\text { urbanization, dogs and cats in household, } \\
\text { special adjustments in house, body mass } \\
\text { index, alcohol and smoking status }\end{array}$ & 1.63 & $1.06-2.52$ & 0.020 & 0.491 & - \\
\hline 3 & Model 1 + medication & & & & & \\
\hline $3 a$ & + Number of medicines & 1.50 & $1.00-2.27$ & 0.058 & 0.408 & 17 \\
\hline 4 & Model $1+$ physical impairments and gener & al hea & & & & \\
\hline $4 a$ & + Pain score & 1.54 & $1.01-2.34$ & 0.044 & 0.431 & 12 \\
\hline \multirow[t]{2}{*}{$4 b$} & + Self-perceived health & 1.55 & $1.05-2.31$ & 0.039 & 0.441 & 10 \\
\hline & + all variables included in models $4 a-b$ & 1.51 & $0.99-2.29$ & 0.056 & 0.410 & 17 \\
\hline 5 & Model 1 + activity and mobility & & & & & \\
\hline $5 a$ & + Physical activity & 1.59 & $1.05-2.41$ & 0.030 & 0.461 & 6 \\
\hline $5 b$ & + Grip strength & 1.58 & $1.05-2.40$ & 0.031 & 0.459 & 7 \\
\hline $5 c$ & + Functional limitations in ADLs & 1.51 & $0.99-2.30$ & 0.054 & 0.412 & 16 \\
\hline \multirow[t]{2}{*}{$5 d$} & + Physical performance & 1.45 & $0.95-2.21$ & 0.084 & 0.371 & 24 \\
\hline & + all variables included in models $5 a-d$ & 1.41 & $0.93-2.16$ & 0.107 & 0.344 & 30 \\
\hline \multirow[t]{2}{*}{6} & Model 1 + Psychosocial functioning & & & & & \\
\hline & + MMSE score $\leq 23$ & 1.59 & $1.05-2.42$ & 0.029 & 0.465 & 5 \\
\hline 7 & Fully adjusted model ${ }^{a}$ & 1.30 & $0.79-2.11$ & 0.300 & 0.259 & 47 \\
\hline
\end{tabular}

${ }^{a}$ Model adjusted for all variables included in models 2 to 6; ADLs, Activities of Daily Living; MMSE, MiniMental Scale Examination. 


\section{Discussion}

We examined the association between diabetes and incident falls among communitydwelling older individuals and found that individuals with diabetes had a $67 \%$ higher risk of recurrent falls than their counterparts without diabetes.

In contrast to previous studies ${ }^{6,7}$, we did not find that the incidence of recurrent falls was particularly higher among the individuals with diabetes who were treated with insulin. Instead, and in line with previous observations ${ }^{12}$ polypharmacy, not the use of any specific medication per se, explained in part the increased risk of recurrent falls in individuals with diabetes. ${ }^{12}$ These observations may have important clinical implications. Diabetes care places a great focus on the prevention of micro- and macrovascular complications, which are often targeted following multidrug regimens in order to control hyperglycaemia and commonly coexisting morbidities such as hypertension, dyslipidaemia, and renal dysfunction. In order to maximize benefits to patients, standardization among health care providers is encouraged through diseasespecific treatment guidelines. ${ }^{23}$ However, the long-term benefits and harms associated with combination of drugs that are taken by individuals with comorbidities is less clear. $^{24}$ In addition, given that levels of clinical control are often sub-optimal, intensification of the overall medication prescribed to individuals with diabetes has been advocated. However, an increased risk of mortality associated with the more intensive use of glucose-lowering drugs ${ }^{25}$ has raised questions about the wisdom of this approach. The potential to increase the incidence of recurrent falls illustrates the complexity of polypharmacy management of older individuals with diabetes.

High levels of chronic musculoskeletal pain are common in the elderly, particularly those with chronic diseases such as diabetes. ${ }^{26,27}$ Our findings suggest that pain may be an important factor to consider in the prevention of diabetes-related falls. The presence of chronic pain may limit the ability of individuals to adhere to selfmanagement practices such as regular exercise ${ }^{26}$, and is also associated with poorer mental health and physical functioning ${ }^{27}$, and thus places an individual with diabetes at greater risk for recurrent falls. ${ }^{28}$ Indeed, among all the potential mediators investigated, poorer levels of physical activity and performance (including gait and balance) seemed to contribute to the increased risk of recurrent falls attributable to diabetes. These findings are in line with several studies showing accelerated loss of muscle strength, functional limitations in ADLs and impairment in physical performance related to diabetes. ${ }^{29-33}$ Importantly, they may be amenable to modification through exercise programs such as resistance/balance training ${ }^{34}$ thereby leading to decreases in falls. ${ }^{35}$ In addition, although exercise may not be an appropriate pain management strategy for every individual, it may reduce pain and improve function, in contrast to the more widely and potentially counterproductive adopted strategies of rest and inactivity. ${ }^{36}$ However, the benefits of exercise as a means to prevent falls among older individuals with diabetes may be hampered in the presence of (severe) cognitive impairment. ${ }^{37}$ Indeed, diabetes is a major risk factor for cognitive 
impairment and dementia ${ }^{38}$ and, in our study; signs of cognitive impairment explained a small part of the increased falls associated with diabetes as well.

Strengths and unique features of this study are its frequent assessment of incident falls over the course of a long-enough period to capture the specific phenotype of interest recurrent falls; the representative population, including both men and women, for the community-dwelling older population of the Netherlands; and the assessment of a large set of potential confounders and mediators of the associations between diabetes and recurrent falls. Despite the comprehensive approach adopted, about half of the diabetes-related increased incidence of recurrent falls remained unexplained. This may have been due to imprecision in identifying relevant factors that mediate an increased risk of falling, such as the presence of peripheral neuropathy. ${ }^{16}$ However, peripheral neuropathy may have been, at least in part, captured by individuals' self-reported levels of pain and/or foot problems, and the measured levels of participants' walking speed, gait and balance (included in the physical performance score), most of which were indeed significantly higher or impaired among the individuals with diabetes. Other potential limitations may include, the fact that we examined (recurrent) falls but not injurious falls specifically.

In addition, although for most participants the diagnosis of diabetes was retrieved from GP's records, in some ( $27 \%)$, these were missing. The diagnosis was therefore based on a combination of data obtained form self-reports and review of glucoselowering medication. In a previous study, the selfreports of diabetes have shown a good agreement with GP's records. ${ }^{39}$ Still, the observed $7.4 \%$ prevalence of diabetes is likely an underestimate since the prevalence of reported diabetes is usually higher in those aged over 65 and diabetes is not infrequently undiagnosed in up to $50 \%$ of cases if screening using blood glucose tests is not performed. ${ }^{40}$ However, if such an underestimate is present, then the strength of the association between diabetes and recurrent falls reported in our study is likely underestimated as well. The reverse is possible if non-diagnosed diabetic subjects fall less than those diagnosed with diabetes. We consider that, however, unlikely as in the diabetes group other risk factors for recurrent falling were more prevalent as well.

Duration of diabetes and measures of $\mathrm{HbA}_{1 \mathrm{c}}$ were also missing and, therefore, we could not ascertain the extent of disease severity/glycaemic control among the individuals with diabetes. Finally, the study population consisted of relatively healthy community-dwelling white persons over 65 and our results may thus not apply to those who are institutionalized or belong to other ethnicities.

In conclusion, older community-dwelling individuals with diabetes have higher risk for recurrent falls than their peers without diabetes. Factors partly explaining this increased risk include diabetes-related polypharmacy, musculoskeletal pain and poorer self-perceived health, lower levels of physical activity and muscle strength, limitations in ADLs, impaired physical performance (including gait and balance), and cognitive impairment. In view of the current ageing of the population and the increase in the incidence of diabetes, particularly among older people, our findings support the view 
that fall prevention efforts targeting the factors identified above may need to be incorporated into the care and treatment of older individuals with diabetes. 


\section{References}

1. Tinetti ME, Kumar C. The patient who falls: "It's always a trade-off". JAMA 2010;303:258-66.

2. Tinetti ME, Williams CS. Falls, injuries due to falls, and the risk of admission to a nursing home. N Engl J Med 1997;337:1279-84.

3. Cumming RG, Kelsey JL, Nevitt MC. Methodologic issues in the study of frequent and recurrent health problems. Falls in the elderly. Ann Epidemiol 1990;1:49-56.

4. Miller DK, Lui LY, Perry HM, 3rd, Kaiser FE, Morley JE. Reported and measured physical functioning in older inner-city diabetic African Americans. J Gerontol A Biol Sci Med Sci 1999;54:M230-6.

5. Hanlon JT, Landerman LR, Fillenbaum GG, Studenski S. Falls in African American and white communitydwelling elderly residents. J Gerontol A Biol Sci Med Sci 2002;57:M473-8.

6. Schwartz AV, Hillier TA, Sellmeyer DE, Resnick HE, Gregg E, Ensrud KE, Schreiner PJ, Margolis KL, Cauley JA, Nevitt MC, Black DM, Cummings SR. Older women with diabetes have a higher risk of falls: a prospective study. Diabetes Care 2002;25:1749-54.

7. Volpato S, Leveille SG, Blaum C, Fried LP, Guralnik JM. Risk factors for falls in older disabled women with diabetes: the women's health and aging study. J Gerontol A Biol Sci Med Sci 2005;60:1539-45.

8. Quandt SA, Stafford JM, Bell RA, Smith SL, Snively BM, Arcury TA. Predictors of falls in a multiethnic population of older rural adults with diabetes. J Gerontol A Biol Sci Med Sci 2006;61:394-8.

9. Gregg EW, Beckles GL, Williamson DF, Leveille SG, Langlois JA, Engelgau MM, Narayan KM. Diabetes and physical disability among older U.S. adults. Diabetes Care 2000;23:1272-7.

10. Wild S, Roglic G, Green A, Sicree R, King H. Global prevalence of diabetes: estimates for the year 2000 and projections for 2030. Diabetes Care 2004;27:1047-53.

11. Shaw JE, Sicree RA, Zimmet PZ. Global estimates of the prevalence of diabetes for 2010 and 2030. Diabetes Res Clin Pract 2010;87:4-14.

12. Huang ES, Karter AJ, Danielson KK, Warton EM, Ahmed AT. The association between the number of prescription medications and incident falls in a multi-ethnic population of adult type-2 diabetes patients: the diabetes and aging study. J Gen Intern Med 2010;25:141-6.

13. Volpato S, Maraldi C, Fellin R. Type 2 diabetes and risk for functional decline and disability in older persons. Curr Diabetes Rev 2010;6:134-43.

14. Lu FP, Lin KP, Kuo HK. Diabetes and the risk of multi-system aging phenotypes: a systematic review and meta-analysis. PLoS One 2009;4:e4144.

15. Ganz DA, Bao Y, Shekelle PG, Rubenstein LZ. Will my patient fall? JAMA 2007;297:77-86.

16. Mayne D, Stout NR, Aspray TJ. Diabetes, falls and fractures. Age Ageing 2010;39:522-5.

17. Deeg DJ, van Tilburg T, Smit JH, de Leeuw ED. Attrition in the Longitudinal Aging Study Amsterdam. The effect of differential inclusion in side studies. J Clin Epidemiol 2002;55:319-28.

18. Pluijm SM, Smit JH, Tromp EA, Stel VS, Deeg DJ, Bouter LM, Lips P. A risk profile for identifying community-dwelling elderly with a high risk of recurrent falling: results of a 3-year prospective study. Osteoporos Int 2006;17:417-25.

19. Peeters GM, van Schoor NM, Pluijm SM, Deeg DJ, Lips P. Is there a U-shaped association between physical activity and falling in older persons? Osteoporos Int 2010;21:1189-95.

20. Kellogg International Work Group on the prevention of falls by the elderly. The prevention of falls in later life. Dan Med Bull 1987;34:1-24.

21. Nevitt MC, Cummings SR, Kidd S, Black D. Risk factors for recurrent nonsyncopal falls. A prospective study. JAMA 1989;261:2663-8.

22. Sterne JA, White IR, Carlin JB, Spratt M, Royston P, Kenward MG, Wood AM, Carpenter JR. Multiple imputation for missing data in epidemiological and clinical research: potential and pitfalls. BMJ 2009; 338:b2393.

23. Nathan DM, Buse JB, Davidson MB, Ferrannini E, Holman RR, Sherwin R, Zinman B; American Diabetes Association; European Association for the Study of Diabetes. Medical management of hyperglycaemia in type 2 diabetes mellitus: a consensus algorithm for the initiation and adjustment of therapy: a consensus statement from the American Diabetes Association and the European Association for the Study of Diabetes. Diabetologia 2009;52:17-30.

24. Tinetti ME, Bogardus ST, Jr., Agostini JV. Potential pitfalls of disease-specific guidelines for patients with multiple conditions. N Engl J Med 2004;351:2870-4. 
25. Action to Control Cardiovascular Risk in Diabetes Study Group, Gerstein HC, Miller ME, Byington RP, Goff DC Jr, Bigger JT, Buse JB, Cushman WC, Genuth S, Ismail-Beigi F, Grimm RH Jr, Probstfield JL, Simons-Morton DG, Friedewald WT. Effects of intensive glucose lowering in type 2 diabetes. N Engl J Med 2008;358:2545-59.

26. Krein SL, Heisler M, Piette JD, Makki F, Kerr EA. The effect of chronic pain on diabetes patients' selfmanagement. Diabetes Care 2005;28:65-70.

27. Bair MJ, Brizendine EJ, Ackermann RT, Shen C, Kroenke K, Marrero DG. Prevalence of pain and association with quality of life, depression and glycaemic control in patients with diabetes. Diabet Med 2010;27:578-84.

28. Leveille SG, Bean J, Bandeen-Roche K, Jones R, Hochberg M, Guralnik JM. Musculoskeletal pain and risk for falls in older disabled women living in the community. J Am Geriatr Soc 2002;50:671-8.

29. Volpato S, Ferrucci L, Blaum C, Ostir G, Cappola A, Fried LP, Fellin R, Guralnik JM. Progression of lowerextremity disability in older women with diabetes: the Women's Health and Aging Study. Diabetes Care 2003;26:70-5.

30. Strotmeyer ES, de Rekeneire N, Schwartz AV, Faulkner KA, Resnick HE, Goodpaster BH, Shorr RI, Vinik Al, Harris TB, Newman AB. The relationship of reduced peripheral nerve function and diabetes with physical performance in older white and black adults: the Health, Aging, and Body Composition (Health ABC) study. Diabetes Care 2008;31:1767-72.

31. De Rekeneire N, Resnick HE, Schwartz AV, Shorr RI, Kuller LH, Simonsick EM, Vellas B, Harris TB; Health, Aging, and Body Composition study. Diabetes is associated with subclinical functional limitation in nondisabled older individuals: the Health, Aging, and Body Composition study. Diabetes Care 2003;26: 3257-63.

32. Park SW, Goodpaster BH, Strotmeyer ES, Kuller LH, Broudeau R, Kammerer C, de Rekeneire N, Harris TB, Schwartz AV, Tylavsky FA, Cho YW, Newman AB; Health, Aging, and Body Composition Study. Accelerated loss of skeletal muscle strength in older adults with type 2 diabetes: the health, aging, and body composition study. Diabetes Care 2007;30:1507-12.

33. Gregg EW, Mangione CM, Cauley JA, Thompson TJ, Schwartz AV, Ensrud KE, Nevitt MC; Study of Osteoporotic Fractures Research Group. Diabetes and incidence of functional disability in older women. Diabetes Care 2002;25:61-7.

34. Allet L, Armand S, de Bie RA, Golay A, Monnin D, Aminian K, Staal JB, de Bruin ED. The gait and balance of patients with diabetes can be improved: a randomised controlled trial. Diabetologia 2010;53: 458-66.

35. Morrison S, Colberg SR, Mariano M, Parson HK, Vinik Al. Balance training reduces falls risk in older individuals with type 2 diabetes. Diabetes Care 2010;33:748-50.

36. Butchart A, Kerr EA, Heisler M, Piette JD, Krein SL. Experience and management of chronic pain among patients with other complex chronic conditions. Clin J Pain 2009;25:293-8.

37. Hauer K, Becker C, Lindemann U, Beyer N. Effectiveness of physical training on motor performance and fall prevention in cognitively impaired older persons: a systematic review. Am J Phys Med Rehabil 2006;85:847-57.

38. Biessels GJ, Staekenborg S, Brunner E, Brayne C, Scheltens P. Risk of dementia in diabetes mellitus: a systematic review. Lancet Neurol 2006;5:64-74.

39. Kriegsman DM, Penninx BW, van Eijk JT, Boeke AJ, Deeg DJ. Self-reports and general practitioner information on the presence of chronic diseases in community dwelling elderly. A study on the accuracy of patients' self-reports and on determinants of inaccuracy. J Clin Epidemiol 1996;49: 1407-17.

40. Ubink-Veltman L, Bilo HJ, Groenier KH, Houweling ST, Rischen RO, Meyboom-de Jong B. Prevalence, incidence and mortality of type 2 diabetes melitus revisited: a prospective population-based study in The Netherlands (ZODIAC-1). Eur J Epidemiol 2003;18:793-800. 


\section{Appendix 4.1}

\section{Additional data for the METHODS section of the manuscript}

[Details can also be found at the Study's Website at http://www.lasa-vu.nl]

\section{Study sample and design}

Briefly, in 1992/93 ( $1^{\text {st }}$ cycle), a random sample of older men and women (aged 55-85 years at baseline), stratified by age, sex, and expected 5 -year mortality was drawn from the population registries of 11 municipalities from 3 distinct geographical areas in the west (Amsterdam and vicinity), the northeast (Zwolle and vicinity) and the south (Oss and vicinity) of The Netherlands. Of the 3805 older persons who were initially approached, $3107(81.7 \%)$ persons were enrolled, and the sample thus obtained is representative of the older Dutch population with respect to geographic region and degree of urbanization. Since the $1^{\text {st }}$ cycle $(1992 / 1993)$ participants have been evaluated at 3-year intervals. Each follow-up data collection consisted of a face-to-face interview (main interview) followed, approximately 2-6 weeks later, by a medical interview, comprising health-related questions, several physical and cognitive tests and a self-administered questionnaire. Both interviews took place at participants' homes, were conducted by specially trained and intensively supervised lay-interviewers and nurses, and were tape-recorded in order to monitor the quality of the data.

\section{Potential confounders}

\section{Socio-demographic and home characteristics}

Age and sex were retrieved from the population registries at study entry. Education level was assessed by asking the participants' about their highest level of education completed, ranging from incomplete elementary school to university education. Responses were categorized as low (elementary school of less), moderate, and high (higher vocational, college or university education). ${ }^{1}$ The degree of urbanization of participants' residence/neighbourhood was assessed applying a postal code tracing system designed by Statistics Netherlands ${ }^{2}$; specifically, this system linked the participants addresses' postal codes to five increasing categories of number of addresses per squared kilometre (ranging from 1 ' $<500$ ' to 5 '>2500 addresses $/ \mathrm{km}^{2}$ ). The presence of $\operatorname{dog}(\mathrm{s})$ and/or cat(s) in the household was determined by means of a question about pets, and the presence of special adjustments in participants' homes, such as extra hand-rails (e.g. in shower/bath or toilet), thresholds removed, raised toilet, etc., were verified by the interviewers. ${ }^{1}$ 


\section{Flow-chart illustrating in detail the study design and sample selection}

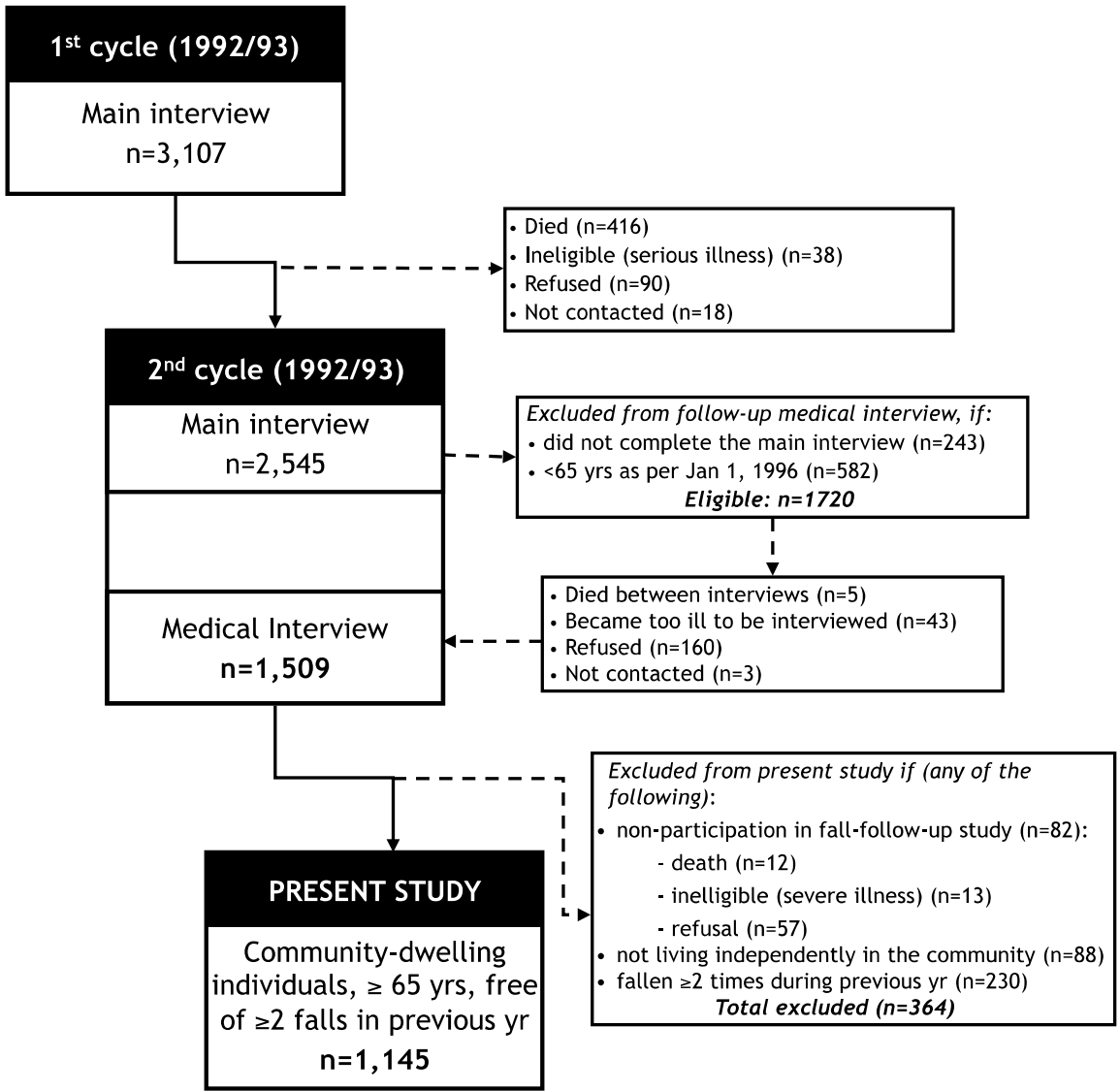

\section{Anthropometry}

Body mass index (in $\mathrm{kg} / \mathrm{m}^{2}$ ) was calculated from body height, measured using a stadiometer to the nearest $0.5 \mathrm{~cm}$, and body weight, measured with a calibrated balance beam scale to the nearest $0.1 \mathrm{~kg}$, with participants wearing light clothing only and no shoes. ${ }^{1}$

\section{Lifestyle}

Current smoking and consumption of alcoholic beverages (yes/no) was assessed with a questionnaire. $^{1}$ 


\section{Potential mediators}

We measured a large set of potential variables that might explain the link between diabetes and incident recurrent falls, if any, and these variables were grouped in domains as explained below.

\section{Co-morbidities and medication}

The presence of somatic chronic diseases was assessed by asking respondents whether they currently had or previously had had any of the following chronic diseases or disease events (yes/no): diabetes mellitus; cardiovascular disease (including coronary artery disease, peripheral artery disease and/or stroke), chronic obstructive pulmonary disease (i.e. asthma, chronic bronchitis and/or pulmonary emphysema), arthritis (i.e. rheumatoid arthritis or osteoarthritis), and/or cancer. Compared to data obtained from GP's records, the accuracy of self-reports of these diseases was shown to be adequate and independent of cognitive impairment. ${ }^{3}$

During the medical interview participants were asked about their current use of prescribed medication. Interviewers examined all medication containers and registered the names, types and doses of drugs. All medicines were then classified according to the international Anatomic, Therapeutic Chemical (ATC)-classification system. ${ }^{4}$ Accordingly, use of medication was categorised into psychotropic (i.e. antipsychotics, anxiolytics, hypnotics, or anti-depressants), blood pressure-lowering, lipidlowering and glucose-lowering (codes A10A, A10B) drugs. In participants with diabetes, data on glucose-lowering drugs was also cross-checked with GP's records, and participants were categorized as those who used insulin, oral or both types of glucoselowering drugs. Polypharmacy was defined as use of $\geq 4$ different drugs.

\section{Physical impairment and general health}

BP was measured while participants reclined in a supine position and after they stood up for $1 \mathrm{~min}$, and orthostatic hypotension was defined as a drop of $\geq 20 \mathrm{mmHg}$ in systolic and/or $\geq 10 \mathrm{mmHg}$ in diastolic BP. ${ }^{5}$

Foot problems included any of the following: sores, plasters, corns, skewed toes, amputation of toe or foot, and/or insufficient muscle function. ${ }^{1}$

Regular dizziness and involuntary loss of urine (yes/no) were assessed through selfreport. $^{1}$

Hearing impairment was assessed by asking individuals firstly whether they could follow a conversation with one person with or without a hearing aid and secondly whether they could hold a conversation with four persons, with or without a hearing aid, and thirdly whether they could use a normal telephone. These questions cover the reduced ability to communicate (understanding of speech in quiet and in noise) the most important indicator of presbyacusis. ${ }^{6}$ Answers to these 3 questions were scored on a 4-point scale: 1 'without difficulty', 2 'with some difficulty', 3 'with much difficulty' 
and 4 'no I cannot', and summed. Based on the total score [range 3-12], participants' hearing status was categorized into 3 categories: good ( $\leq 4$ points), insufficient ( 5 points) and poor ( $\geq 6$ points). Visual impairment was assessed by questioning the participants on whether they could read the small print in a newspaper and recognize someone's face at a distance of $4 \mathrm{~m}$ (with glasses or contact lenses if needed). ${ }^{7}$ Both questions were scored on a 4-point scale, similar to that of hearing impairment, and summed to a total score [range 2-8]. Participants' visual status was categorized into good ( 2 points), insufficient ( 3 points) and poor ( $\geq 4$ points).

Subjective overall body pain was assessed with a questionnaire based on a subscale of the Dutch version of the Nottingham Health Profile. ${ }^{8,9}$ This scale included six questions about pain, any pain (yes/no) and pain in situations and activities relevant to daily life (i.e. standing, walking, sitting, and changing position, or continual pain). The total score [range: 0-6] was also used to characterize individuals as without (score 0 ) or with any pain (scores 1-6). ${ }^{8}$

Self-rated health was obtained by questionnaire with 5 response categories, ranging for 1 'excellent' to 5 'poor'. Hospital admissions in previous 6 months (y/n) as well as falls in previous year were assessed by self-report. ${ }^{1}$ Note that since we have excluded from the analyses subjects with $\geq 2$ falls in previous year, these data thus refer to occasional falls in previous year $(\mathrm{y} / \mathrm{n})$.

\section{Activity, muscle strength and mobility}

Level of physical activity (in min/day) was assessed with the LASA Physical Activity Questionnaire (LAPAQ), a validated interview-administered questionnaire for older persons, covering household activities, sports, walking outdoors and bicycling during the previous 2 weeks. ${ }^{10-12}$

Hand-grip strength (in $\mathrm{kg}$ ) was measured using a strain-gauged dynamometer (Takei TKK 5001, Takei Scientific Instruments Co. Ltd, Tokyo, Japan). Participants were asked to perform two maximum force trials with each hand; the maximum values of the right and left hands were summed and used as a final measure of muscle strength. ${ }^{13,14}$

Functional limitations were assessed with a validated questionnaire concerning the degree of difficulty in the following 6 activities of daily living (ADLs): climbing stairs, walking 5 min outdoors without resting, getting up and sitting down on a chair, dressing and undressing oneself, cutting one's own toenails, and using own or public transportation. A total score ranging from 0 to 6 , was assigned to participants who did not report any difficulty (0) to difficulties in all 6 ADLs (6). ${ }^{11,12,14}$

Physical performance tests comprised timed walking (time needed to walk $3 \mathrm{~m}$, turn $180^{\circ}$ and walk back as fast as possible), chair stands (time needed to stand up and sit down five times with arms folded) and tandem stand (ability to stand unsupported with one foot placed behind the other - heel against toe - for at least 10s) tests. ${ }^{15}$ Participants completing the walking and chair stand tests were assigned the scores 1-4, corresponding to the quartiles of time needed to complete the tests, with the fastest 
time scored 4 . Those who could not complete the tests were assigned a score of 0 . For the tandem stand test, 0 points were assigned to those who could not perform the test, 2 points to those who stood $<10$ s, and 4 points to those who stood $\geq 10$ s. The three items were summed into a final score [range: $0-12$ ]. ${ }^{11,12,14}$

\section{Psychosocial health}

General cognitive functioning was measured using the Mini-Mental State Examination (MMSE). ${ }^{16}$. The scale consists of 21 items and scores range from 0 to 30, with higher scores indicating better cognitive functioning and a score $\leq 23$ indicating impaired cognitive function. ${ }^{16-18}$

The presence of depressive symptoms was assessed by means of the Dutch version of the Center for Epidemiologic Studies Depression Scale [CES-D, range 0-60]. ${ }^{19} \mathrm{~A}$ clinically relevant level of depressive symptoms was considered present when the total score was $\geq 16$. $^{8,20}$

Fear of falling was measured with the use of an adapted version of the Falls Efficacy Scale [FES, range 0-30] by asking the participants how concerned he/she felt to fall during 10 activities of daily living. ${ }^{21}$ The 10 activities included cleaning the house, (un)dressing, preparing simple meals, bathing/showering, shopping, getting in/out of a chair, going up/down stairs, walking in the neighbourhood, reaching in a deep/low cupboard, and answering the phone. Instead of the original 10-point rating scale, answers to the each question were scored on a scale ranging from 0 (not concerned), to 3 (very concerned).

Feelings of loneliness were defined as the unpleasant experience that occurs when a person's network of social relationships is perceived to be deficient either quantitatively or qualitatively were measured by a validated 11 -item scale. ${ }^{22}$ Answers were given on a 3-point scale of which the middle and high categories were combined to calculate sum scores [range 0-11]. In addition, participants were asked whether they were living alone or together with a partner and/or others in the same household. ${ }^{1,23}$

\section{Biochemistry}

Blood samples were obtained in the morning. Participants were allowed to have tea and toast, but no dairy products. Blood samples were immediately centrifuged and serum was stored at $-20^{\circ} \mathrm{C}$ until assay determination, as described in detail elsewhere ${ }^{13,14,17,20,24,25}$, and briefly below.

25-hydroxyvitamin $D$ was determined according to competitive protein binding assay (Nichols Diagnostics, San Juan Capistrano, CA, USA; inter-assay CV of $10 \% .{ }^{13,20}$ Sex hormone-binding globulin and parathyroid hormone were measured by means of immunoradiometric assays (Orion Diagnostica, Espoo, Finland, and Incstar Corp., Stillwater, MN, USA, respectively; inter-assay CVs of $12 \%) .{ }^{13,14,20}$ Osteocalcin was measured by an immunoradiometric assay (Biosource/Medgenix Diagnostics, Fleuris, Belgium; inter-assay CV of $8 \% .{ }^{25}$ Insulin-like growth factor-1 was determined by 
immunoradiometric assay after extraction (DSL,Webster, Texas, USA, inter-assay $\mathrm{CV}<14 \%) .{ }^{18}$ The levels of $\mathrm{C}$-reactive protein and interleukin- 6 were determined using sensitive regular ELISA immunoassays (inter-assay $\mathrm{CV} s<5 \%$ ). ${ }^{17}$ Albumin concentrations were determined by using either a bromecresol green (BCG) photometric assay or a bromecresol purple (BCP) method; to enable comparability, albumin levels determined with the BCP method were calibrated to the BCG method using a validated formula $(B C G=B C P+5.5) .{ }^{24}$ Creatinine level was measured using the Jaffé alkaline picrate reaction with a Hitachi 747 analyser and was used to estimate glomerular filtration rate (eGRF) by the abbreviated prediction equation developed by the Modification of Diet in Renal Disease Study. ${ }^{26}$

\section{Statistical Analyses - multiple imputation of missing data}

Incomplete data were imputed with values estimated from regression models on all the other study variables including outcome. Because in this study outcome is time to event (recurrent falls), we used the event indicator and the Nelson-Aalen estimator of the cumulative baseline hazard function in these imputed models. ${ }^{27}$ We generated five imputed datasets that were used to fit the regression models of interest; results reported were those retrieved from pooled analyses in all 5 imputed datasets. Noteworthy, number of missing observations did not differ between subjects with and without diabetes, or between recurrent and non-recurrent fallers.

\section{References (methods)}

1. Schaap LA, Pluijm SM, Deeg DJ, Visser M. Inflammatory markers and loss of muscle mass (sarcopenia) and strength. Am J Med 2006; 119: 526 e9-17.

2. den Dulk CJ, van de Stadt H, Vliegen JM. Een nieuwe maatstaf voor stedelijkheid: De omgevingsadressendichtheid \{A new measure for degree of urbanization: The address density of the surrounding area]. Maandstatistiek van de Bevolking 1992; 40: 14-27.

3. Kriegsman DM, Penninx BW, van Eijk JT, Boeke AJ, Deeg DJ. Self-reports and general practitioner information on the presence of chronic diseases in community dwelling elderly. A study on the accuracy of patients' self-reports and on determinants of inaccuracy. J Clin Epidemiol 1996; 49: 1407 17.

4. WHO Collaborating Centre for Drug Statistics Methodology. [http://www.whocc.no/atcddd]. 2007; Available from: [http://www.whocc.no/atcddd].

5. Mader SL. Orthostatic hypotension. Med Clin North Am 1989; 73: 1337-49.

6. Kramer SE, Kapteyn TS, Kuik DJ, Deeg DJ. The association of hearing impairment and chronic diseases with psychosocial health status in older age. J Aging Health 2002; 14: 122-37.

7. de Boer MR, Pluijm SM, Lips P, Moll AC, Völker-Dieben HJ, Deeg DJ, van Rens GH. Different aspects of visual impairment as risk factors for falls and fractures in older men and women. $J$ Bone Miner Res 2004; 19: 1539-47.

8. Geerlings SW, Twisk JW, Beekman AT, Deeg DJ, van Tilburg W. Longitudinal relationship between pain and depression in older adults: sex, age and physical disability. Soc Psychiatry Psychiatr Epidemiol 2002; 37: 23-30.

9. Hunt SM, McEwen J, McKenna SP. Measuring health status: a new tool for clinicians and epidemiologists. J R Coll Gen Pract 1985; 35: 185-8.

10. Stel VS, Smit JH, Pluijm SM, Visser M, Deeg DJ, Lips P. Comparison of the LASA Physical Activity Questionnaire with a 7-day diary and pedometer. J Clin Epidemiol 2004; 57: 252-8. 
11. Visser M, Pluijm SM, Stel VS, Bosscher RJ, Deeg DJ. Physical activity as a determinant of change in mobility performance: the Longitudinal Aging Study Amsterdam. J Am Geriatr Soc 2002; 50: 1774-81.

12. Peeters GM, van Schoor NM, Pluijm SM, Deeg DJ, Lips P. Is there a U-shaped association between physical activity and falling in older persons? Osteoporos Int 2009; 21: 1189-95.

13. Visser M, Deeg DJ, Lips P. Low vitamin D and high parathyroid hormone levels as determinants of loss of muscle strength and muscle mass (sarcopenia): the Longitudinal Aging Study Amsterdam. J Clin Endocrinol Metab 2003; 88: 5766-72.

14. Schaap LA, Pluijm SM, Smit JH, van Schoor NM, Visser M, Gooren LJ, Lips P. The association of sex hormone levels with poor mobility, low muscle strength and incidence of falls among older men and women. Clin Endocrinol (Oxf) 2005; 63: 152-60.

15. Guralnik JM, Simonsick EM, Ferrucci L, Glynn RJ, Berkman LF, Blazer DG, Scherr PA, Wallace RB. A short physical performance battery assessing lower extremity function: association with self-reported disability and prediction of mortality and nursing home admission. J Gerontol 1994; 49: M85-94.

16. Folstein MF, Folstein SE, McHugh PR. "Mini-mental state". A practical method for grading the cognitive state of patients for the clinician. J Psychiatr Res 1975; 12: 189-98.

17. Dik MG, Jonker C, Hack CE, Smit JH, Comijs HC, Eikelenboom P. Serum inflammatory proteins and cognitive decline in older persons. Neurology 2005; 64: 1371-7.

18. Dik MG, Pluijm SM, Jonker C, Deeg DJ, Lomecky MZ, Lips P. Insulin-like growth factor I (IGF-I) and cognitive decline in older persons. Neurobiol Aging 2003; 24: 573-81.

19. Beekman AT, Deeg DJ, Van Limbeek J, Braam AW, De Vries MZ, Van Tilburg W. Criterion validity of the Center for Epidemiologic Studies Depression scale (CES-D): results from a community-based sample of older subjects in The Netherlands. Psychol Med 1997; 27: 231-5.

20. Hoogendijk WJ, Lips P, Dik MG, Deeg DJ, Beekman AT, Penninx BW. Depression is associated with decreased 25-hydroxyvitamin $D$ and increased parathyroid hormone levels in older adults. Arch Gen Psychiatry 2008; 65: 508-12.

21. Tinetti ME, Richman D, Powell L. Falls efficacy as a measure of fear of falling. J Gerontol 1990; 45: P239-43.

22. de Jong-Gierveld J, Kamphuis F. The development of a Rasch-type loneliness-scale. Appl Psychol Meas 1987; 1985: 289-99.

23. Kriegsman DM, van Eijk JT, Penninx BW, Deeg DJ, Boeke AJ. Does family support buffer the impact of specific chronic diseases on mobility in community-dwelling elderly? Disabil Rehabil 1997; 19: 71-83.

24. Schalk BW, Visser M, Bremmer MA, Penninx BW, Bouter LM, Deeg DJ. Change of serum albumin and risk of cardiovascular disease and all-cause mortality: Longitudinal Aging Study Amsterdam. Am J Epidemiol 2006; 164: 969-77.

25. Kuchuk NO, Pluijm SM, van Schoor NM, Looman CW, Smit JH, Lips P. Relationships of serum 25hydroxyvitamin $D$ to bone mineral density and serum parathyroid hormone and markers of bone turnover in older persons. J Clin Endocrinol Metab 2009; 94: 1244-50.

26. Levey AS, Bosch JP, Lewis JB, Greene T, Rogers N, Roth D. A more accurate method to estimate glomerular filtration rate from serum creatinine: a new prediction equation. Modification of Diet in Renal Disease Study Group. Ann Intern Med 1999; 130: 461-70.

27. White IR, Royston P. Imputing missing covariate values for the Cox model. Stat Med 2009; 28: $1982-98$ 


\section{Appendix 4.2}

\section{Additional data for the RESULTS section of the manuscript}

\section{Additional analyses}

Even though 25-hydroxyvitamin D was lower and hearing impairments and C-reactive protein were higher among individuals with diabetes, they were not associated with recurrent falls in models adjusted for study confounders and could thus not explain the increased risk of recurrent falls in these individuals vs. their counterparts without diabetes (data not shown). Conversely, in multivariate analyses adjusted for confounders and diabetes status, factors such as use of psychotropic drugs, [HR=1.81 (95\% Cl: 1.32-2.48)], arthritis [HR=1.31 (1.01-1.71)], regular dizziness [HR=1.66 (1.192.30)], incontinence $[H R=1.43$ (1.06-1.93)], poor vision [HR=1.58 (1.13-2.21)], prior hospital admission [HR=1.67 (1.14-2.49)], occasional fall in previous year [HR=1.89 (1.43-2.51)], higher CES-D scores [HR=1.03 (1.02-1.05)] and feelings of loneliness [HR=1.06 (1.01-1.11)] were all associated with greater risk of recurrent falls, but did not explain the differences between individuals with vs. without diabetes because they did not differ between the two groups.

We also examined the extent to which loss to follow-up could have affected our estimates of incident risk for recurrent falls associated with diabetes. Specifically, among the 913 subjects classified as non-recurrent fallers, 147 (13\% of the whole study population) were lost to follow-up, due to the following reasons: death (106), refusal (32), too ill to continue follow-up $(n=4)$, and not contacted $(n=5)$, and therefore their follow-up time was censored before the end of the study. We have then recoded all these 147 participants to recurrent fallers shortly after the last known date of follow-up to examine the estimates for the association of diabetes with incident recurrent falls in a 'worst-case scenario'. Estimates obtained this scenario were $\mathrm{HR}=1.57$ (95\% $\mathrm{Cl}: 1.13-2.18)$ in unadjusted analyses and $\mathrm{HR}=1.57$ (1.14-2.16) in analyses adjusted for study confounders; further adjustments for the potential mediators (as shown in manuscript's Table 3, model 7) attenuated this association by $\sim 49 \%$ to 1.26 (0.90-1.77). In conclusion, loss to follow-up did not change the inferences arising from our study. 



\section{Chapter 5}

Predicting mortality of psychogeriatric patients:

a simple prognostic frailty risk score

E Pijpers, I Ferreira, RJJ van de Laar, CDA Stehouwer, AC Nieuwenhuijzen Kruseman

Postgrad Med J. 2009;85:464-9. 


\section{Abstract}

\section{Background}

Frailty and mortality in psychogeriatric patients are hard to predict but important in counselling and therapeutic decision making. We have therefore developed a simple frailty risk score to predict mortality this population.

\section{Study design}

Prospective observational study including 401 community dwelling psychogeriatric patients (249 women; mean (SD) age 78.0(6.5) years), who had been referred to a multidisciplinary diagnostic observation centre. We made cox proportional hazards regression models to identify and selected baseline characteristics for the development and validation of a risk score for the prediction of 3 year mortality.

\section{Results}

A total of 116 subjects died during follow-up.(median follow-up duration of 26 months) Baseline characteristics associated with mortality were: age (HR 1.44, 95\% confidence interval(Cl) 1.02 to 2.04), male sex (HR 2.93, 95\% Cl 1.89 to 4.59 ), living alone ( $\mathrm{HR} 1.53,95 \% \mathrm{Cl}: 0.99$ to 2.38 ), body mass index (BMI) $<18.5 \mathrm{~kg} / \mathrm{m} 2$ (HR 4.09, $95 \% \mathrm{Cl} 2.06$ to -8.14 ), cardiovascular disease (HR 1.42, $95 \% \mathrm{Cl} 0.94$ to 2.15 ), elderly mobility score $<20$ (HR $1.92, \mathrm{Cl} 1.24$ to 2.98 ), number of medicines $\geq 2$ (HR 2.28, 95\% 1.21 to 4.31 ), and impaired motor ( $\mathrm{HR} 1.47,95 \% \mathrm{Cl} 0.93$ to 2.32 ) and process skills (HR $1.92,95 \% \mathrm{Cl} 1.12$ to 2.98 ) in activities of daily living. These predictors were translated into an easy-to-use frailty risk score and patients were stratified into very good ( $<45$ points), good (45-50) moderate (51-55), poor (56-61) and very poor (>61) prognosis groups. Three-year mortality rates across these groups were $8.0 \%, 15.9 \%, 25.9 \%, 41.5 \%$ and $68.8 \%$, respectively $(p<0.001)$. The area under the receiver operating characteristic curve (AUC) of the risk score was $0.78(95 \% \mathrm{Cl} 0.73$ to 0.82$)$, indicating good discriminative performance.

\section{Conclusions}

We developed and validated a risk score for the prediction of 3-years mortality. This risk score can de used to stratify patients into different risk categories, thereby making patient counselling and tailored diagnostic and therapeutic decisions in clinical practice possible. 


\section{Introduction}

A substantial number of people over the age of 65 years are considered frail. The percentages reported vary between 10 and $20 \%$, and rise with increasing age, to $45 \%$ over the age of 85 years. $^{1}$ Frail individuals are at high risk for dependency, institutionalisation, falls, injuries, hospitalisation, slow recovery from any illness and mortality. They are therefore most in need of health care and community and informal support services.

Although readily recognisable to experienced clinicians and described as a multidimensional phenotype $e^{1-3}$, frailty has been difficult to define. There are different views on how to move from the many manifestations of frailty arising from multiple abnormalities in bio-psychosocial mechanisms to a restricted number of critical characteristics that can be used to diagnose frailty. Several approaches have been developed for this purpose. ${ }^{2,4-7}$ Most of these are complex and time-consuming and depend on clinician's experience, and have limited use in clinical practice. Most have been developed in the general elderly population but none apply specifically to older patients with acquired mental disorders (for example dementia). Identification of the specific frailty characteristics associated with worse outcomes in these patients, and their operationalisation into a valid and "quick and easy" to use risk score that does not particularly rely on clinician's experience, is a much-needed tool for clinical practise.

Therefore we investigated, in a group of older psychogeriatric subjects in an outpatient setting, which characteristics at first evaluation would contribute to the recognition of the frailest individuals, based on their association with increased mortality risk. Subsequently, these characteristics were used to develop and validate a frailty risk score to aid in the risk stratification of patients and subsequent medical decision making tailored to patients' needs.

\section{Methods}

\section{Study population and follow-up}

The study population consisted of a cohort of community dwelling subjects, aged 55 years and older, who had been referred to the Diagnostic Observation Centre for PsychoGeriatric patients (DOC-PG) of the Maastricht University Hospital, the Netherlands between 1 May 2002 and 1 January $2006(n=454)$. The DOC-PG is a regional advisory centre for general practices that provides a multidisciplinary assessment of older patients suspected to have a complex combination of cognitive and somatic disorders, and an estimate of the required levels of care. Baseline assessments were conducted within 2 weeks after referral with a home visit and two outpatient appointments at the hospital and included somatic and psychogeriatric 
screening. A diagnosis and treatment plan were formulated at a weekly multidisciplinary meeting and a report was sent to the general practitioner with multiaxis diagnoses and treatment recommendations. ${ }^{13}$ All subjects were then monitored through follow-up visits (every 6 months) to the memory clinic of the University Hospital or were visited at home by trained ambulatory mental health nurses.

Subjects were followed up until death (study main outcome) or up to 1 januari 2007 (study closing date). Mortality data (that is, the exact date of death) were retrieved from hospital, general practitioner, nursing and care homes and local council mortality registries. Vital status at the study closing date was successfully obtained in all patients.

Subjects living in a nursing home and thus presumed to be extremely frail $(n=53)$ were excluded from this study. The present study therefore consisted of 401 patients (249 women) with a mean (SD) age of $78.0 \pm 6.5$ years. According to the Diagnostic and statistical manual of mental disorders, $4^{\text {th }}$ revision (DSM-IV) criteria ${ }^{9}, 80.8 \%$ of the study population was diagnosed with dementia (from the remaining, $5 \%$ with depression, $11.2 \%$ with other type of, and $3.0 \%$ with no mental disorder). All patients included or their carers or proxies gave informed consent for the use of data gathered. The study was approved by the medical ethical committee of the University Hospital Maastricht.

\section{Potential predictor variables}

A number of validated practical tests and parameters covering five general domains of frailty were used as potential predictors of mortality. ${ }^{2,3,6,10-12}$ These included sociodemographic, medical, nutrition, physical function, and cognitive function variables, as specified below. All variables, with the exception of age, were dichotomised using, whenever available, standardized cut-off values.

Sociodemographic parameters included age, sex, and living alone. Living conditions and the presence of a carer/partner, indicative of direct social support, were evaluated at home by a trained mental health nurse and later confirmed in a structured interview.

Medical predictors included co-morbidity and sensory deficits such as visual and hearing impairment and incontinence, assessed by a detailed medical history obtained during the baseline visit. The hospital electronic patient files also were reviewed and diseases encountered were retrieved. Co-morbidities were categorized into cardiovascular disease, chronic obstructive pulmonary disease, cancer, diabetes mellitus and auto-immune disease. A Charlson co-morbidity index was calculated. ${ }^{18}$ Renal function was estimated by a glomerular filtration rate (eGFR) calculated with the Cockcroft and Gault formula. An eGFR of $<60 \mathrm{ml} / \mathrm{min}$ was considered indicative of renal dysfunction. ${ }^{14}$ Finally, the number of medicines used was counted. Polypharmacy was defined as the use of 2 or more medicines. Sensory deficits were scored on the 
basis of self-reported or carer's observed impairment of eyesight and sense of hearing and use of incontinence-material. ${ }^{6,12}$

Nutritional predictors included body mass index $(B M I)<18.5 \mathrm{~kg} / \mathrm{m}^{2}$ (indicating underweight), weight loss and low albumin levels (i.e. $<34 \mathrm{~g} / \mathrm{l}$ ). Categories of BMI indicating overweight ( $\geq 25$ to $<30 \mathrm{~kg} / \mathrm{m}^{2}$ ) and obesity (i.e. $\geq 30 \mathrm{~kg} / \mathrm{m}^{2}$ ) were not included as predictors because in preliminary analyses, mortality rates did not differ between these subjects and those with normal weight. Weight loss occurring in the course of the past 3 to six months was reported by the patient or his/her carer and expressed as present or absent. Albumin levels were measured in plasma using the bromcresol purple method and rounded off to the first decimal. ${ }^{15}$

Physical function predictors included measures of mobility and disability. Mobility was evaluated by a physiotherapist using the Elderly Mobility Scale (EMS) ${ }^{16}$ On the basis of the performances on the seven items comprised in the EMS a total score was calculated and impaired mobility defined whenever the score was $<20$ points. Disability in activities of daily living ( $A D L$ ) was assessed by a qualified occupational therapist using the Assessment of Motor and Process Skills (AMPS) too ${ }^{17}$ Briefly, the AMPS is an observational measure of functional competence in instrumental activities of daily living tasks and assesses those aspects of functioning that are essential for people to live independently in the community.

Cognitive function was evaluated by a trained mental nurse and a psychiatrist with the use of the Mini Mental State Examination (MMSE) tool with a cut-off value <24 considered indicative of impaired cognitive function. ${ }^{16}$

\section{Statistical analyses}

All statistical analyses were carried out using the STATA software package version 9.2 (STATA Corp, College Station, Texas, USA).

\section{Multiple imputation of missing values of predictor variables}

Fifty subjects had missing values for one $(n=39)$, two $(n=4)$, three $(n=4)$ or five $(n=3)$ predictor variables. The number of missing values per variable varied from $0.2 \%$ to 4.7\%. We used imputation chained equations (procedure 'ICE' available in STATA) to impute those missing values (total of $0.8 \%$ off all required values) rather than perform complete case analyses, not only to boost power in the analyses but also to extract more valid estimates. ${ }^{19}$

\section{Development of the predictive model and risk score}

We used Cox's proportional hazards models to determine the association (that is. the coefficients) between the frailty variables examined and incident mortality. Firstly we performed univariate analyses and hazard ratios (HRs) and respective $95 \%$ confidence intervals $(\mathrm{Cl})$ were presented for each potential predictor. All potential predictors were 
then entered simultaneously into a multivariate model that was reduced to a most parsimonious model using a backward selection method based on the reduction of Akaike's Information Criterion. To prevent overlap (i.e. multi-collinearity), we chose to enter each disease and condition separately into the multivariate model instead of using the combined Charlson score. The proportional hazards assumption of the model was not violated as examined graphically and tested with the use of the Schoenfeld's residuals, and we found no departures from linearity for the continuous variable as examined graphically with the use of the partial Martingale residuals. We investigated all possible interactions between age and/or sex and all the other variables retained in the final model, but no significant interactions were found.

The regression coefficients of the variables retained in the predictive model were combined with the patients' characteristics (the score predictor) and also the baseline survivor function at 3 years (estimated from the Cox regression model) to estimate each patient's 3-year probability of death. (see footnote of Table 5.3 for details on how probabilities were computed and also on how probabilities at other time points can be extracted)

\section{Development of the risk score}

For ease of application, we converted the score predictor obtained in the Cox model to an integer risk score. This was done by multiplying each coefficient by a factor of 10 (rounded to the nearest integer), then by the patients' characteristics value, and then summing the results. Each predictor was thus weighted proportionally to the strength of its association with mortality.

\section{Internal validity}

Our measure of model discriminative performance was the area under the receiveroperating characteristic (ROC) curve (AUC), which is comparable to the $C$ statistic and reflects the ability of the risk score to correctly assign a higher mortality probability to a person who died within 3-years than to a person who survived beyond 3 years. These ROC curves were computed according to time-dependent methods which are more appropriate for censored survival times. ${ }^{20}$ However, because predictive models are thought to provide too optimistic estimates during their derivation phase, we used bootstrapping techniques for internal validation of the AUC of the model. ${ }^{21} \mathrm{We}$ also calculated the $\mathrm{R}^{2}$ statistic, which is a measure of the explained variance of the model. ${ }^{22}$ Finally, to assess calibration (i.e. the degree of similarity between observed and predicted risk) the mean predicted 3-year mortality risk and the observed 3-year mortality (obtained using the 3-year Kaplan-Meier estimate) were compared in each quintile of the risk score (estimated as described above). These 5 prognostic groups (of approximately equal size, $\mathrm{n}=80$ or 81 ) were labelled as 'very good', 'good', 'moderate', 'poor' and 'very poor' prognosis. 


\section{Results}

The study's median follow-up duration was 26 (interquartile range 18-37) months. One hundred and sixteen patients (28.9\%) died during the course of follow-up (incidence rate of mortality $=10.6$ per 1000 person-years). Baseline characteristics of subjects who died and those who were still alive after follow-up are summarised in Table 5.1.

Table 5.1 Baseline characteristics of the DOC-PG study population.

\begin{tabular}{|c|c|c|c|}
\hline Characteristics & & Survived $(n=285)$ & Died $(n=116)$ \\
\hline \multicolumn{4}{|l|}{ Socio-demographic } \\
\hline Age, years & & $77.4 \pm 6.4$ & $79.7 \pm 6.5$ \\
\hline Male sex & & $96(33.7)$ & $56(48.3)$ \\
\hline Living alone & & $137(48.1)$ & $62(53.4)$ \\
\hline \multicolumn{4}{|l|}{ Medical } \\
\hline Cardiovascular disease & & $123(43.2)$ & $71(61.2)$ \\
\hline COPD & & $23(8.1)$ & $12(10.3)$ \\
\hline Cancer & & $26(9.1)$ & $7(6.0)$ \\
\hline Diabetes & & $48(16.8)$ & $25(21.6)$ \\
\hline Auto-immune disease & & $15(5.3)$ & $4(3.4)$ \\
\hline \multirow[t]{4}{*}{ Charlson score, points } & & $1[0-2]$ & $2[1-3]$ \\
\hline & $0-1$ & $161(56.5)$ & $50(43.1)$ \\
\hline & $2-3$ & $88(30.9)$ & $45(38.8)$ \\
\hline & $\geq 4$ & $36(12.6)$ & $21(18.1)$ \\
\hline \multirow[t]{2}{*}{$\mathrm{eGRF}, \mathrm{ml} / \mathrm{min}$} & & $53.1 \pm 18.0$ & $56.1 \pm 18.7$ \\
\hline & $<60$ & $193(67.7)$ & $75(64.7)$ \\
\hline \multirow[t]{2}{*}{ Medication, no. } & & $3[1-6]$ & $4[2-7]$ \\
\hline & $\geq 2$ & $210(73.7)$ & $97(83.6)$ \\
\hline Visual problems & & $75(25.3)$ & $30(25.9)$ \\
\hline Hearing problems & & $106(37.2)$ & $53(45.7)$ \\
\hline Incontinence & & $83(29.1)$ & $41(35.3)$ \\
\hline \multicolumn{4}{|l|}{ Nutritional } \\
\hline \multirow[t]{2}{*}{$\mathrm{BMI}, \mathrm{kg} / \mathrm{m}^{2}$} & & $25.3 \pm 3.9$ & $24.8 \pm 5.0$ \\
\hline & $<18.5$ & $7(2.5)$ & $11(9.5)$ \\
\hline Weight loss & & $103(36.1)$ & $39(33.6)$ \\
\hline \multirow[t]{2}{*}{ Albumin, g/L } & & $39.4 \pm 3.2$ & $38.3 \pm 3.2$ \\
\hline & $<34$ & $9(3.2)$ & $10(8.6)$ \\
\hline \multicolumn{4}{|l|}{ Physical function } \\
\hline \multirow[t]{2}{*}{ EMS, points } & & $20[18-20]$ & $18[16-20]$ \\
\hline & $<20$ & $80(28.1)$ & $64(55.2)$ \\
\hline Motor deficit in ADL & & $117(41.1)$ & $71(61.2)$ \\
\hline Process deficit in ADL & & $186(65.3)$ & $97(83.6)$ \\
\hline \multicolumn{4}{|l|}{ Cognitive function } \\
\hline \multirow[t]{2}{*}{ MMSE score, points } & & $23[19-25]$ & $21[15-24]$ \\
\hline & $\leq 24$ & $159(55.8)$ & $86(74.1)$ \\
\hline
\end{tabular}

Data are means \pm standard deviation, median [inter-quartile range] or frequency (percentages); COPD, chronic obstructive pulmonary disease; eGFR: estimated glomerular filtration rate, BMI, body mass index; EMS, Elderly Mobility Score; ADL, Activities of daily living; MMSE, Mini Mental State Examination. 
In univariate analyses, older age, male sex, cardiovascular disease, a higher Charlson score, the use of 2 or more medicines, hearing problems, incontinence, a BMI below $18.5(25) \mathrm{kg} / \mathrm{m}^{2}$, an albumin level below $34 \mathrm{~g} / \mathrm{l}$, an EMS score below 20 points, deficits in ADL motor and process skills, and a MMSE score below 24 points were the baseline characteristics significantly associated with mortality (Table 5.2).

Table $5.2 \quad$ Unadjusted hazard ratios of death associated with baseline characteristics.

\begin{tabular}{|c|c|c|c|c|}
\hline & & $\mathrm{HR}$ & $95 \% \mathrm{Cl}$ & $P$-value \\
\hline Age, per 10 years & & 1.75 & $1.28-2.38$ & $<0.001$ \\
\hline Male Sex & & 1.70 & $1.18-2.44$ & 0.004 \\
\hline Living alone & & 1.22 & $0.84-1.75$ & 0.290 \\
\hline Cardiovascular disease & & 1.85 & $1.27-2.69$ & 0.001 \\
\hline COPD & & 1.13 & $0.62-2.06$ & 0.683 \\
\hline Cancer & & 1.02 & $0.47-2.20$ & 0.956 \\
\hline Diabetes & & 1.48 & $0.95-2.30$ & 0.085 \\
\hline Auto-immune disease & & 0.90 & $0.33-2.44$ & 0.834 \\
\hline \multirow[t]{2}{*}{ Charlson score } & $1-2$ vs. 0 & 1.61 & $1.07-2.41$ & 0.021 \\
\hline & $\geq 3$ vs. 0 & 2.25 & $1.35-3.77$ & 0.002 \\
\hline eGRF $<60 \mathrm{ml} / \mathrm{min}$ & & 1.10 & $0.75-1.62$ & 0.662 \\
\hline Medication no. $\geq 2$ & & 2.08 & $1.27-3.41$ & 0.004 \\
\hline Visual problems & & 1.14 & $0.75-1.72$ & 0.545 \\
\hline Hearing problems & & 1.60 & $1.09-2.30$ & 0.015 \\
\hline Incontinence & & 1.49 & $1.02-2.19$ & 0.040 \\
\hline $\mathrm{BMI}<18.5 \mathrm{~kg} / \mathrm{m}^{2}$ & & 1.99 & $1.06-3.71$ & 0.031 \\
\hline Weight loss & & 1.00 & $0.68-1.47$ & 0.993 \\
\hline Albumin $<34 \mathrm{~g} / \mathrm{l}$ & & 2.59 & $1.35-4.97$ & 0.004 \\
\hline EMS score $<20$ & & 2.60 & $1.80-3.76$ & $<0.001$ \\
\hline Motor deficit in ADL & & 2.32 & $1.59-3.78$ & $<0.001$ \\
\hline Process deficit in ADL & & 2.27 & $1.39-3.72$ & 0.001 \\
\hline MMSE score $\leq 24$ & & 1.79 & $1.18-2.72$ & 0.006 \\
\hline
\end{tabular}

COPD, chronic obstructive pulmonary disease; eGFR: estimated glomerular filtration rate, BMI, body mass index; EMS, Elderly Mobility Score; ADL, Activities of daily living; MMSE, Mini Mental State Examination.

\section{Independent predictors of mortality}

Characteristics retained in the final prognostic model were age, male sex, living alone, $\mathrm{BMI}<18.5 \mathrm{~kg} / \mathrm{m}^{2}$, cardiovascular disease, diabetes, use of 2 or more medicines, EMS below 20 points and deficits in ADLS motor and process skills (Table 5.3).

The area under the curve (AUC) of this model for the prediction of 3-year mortality risk was $0.78(95 \% \mathrm{Cl}: 0.71-0.84)$ indicating good discriminative performance. Bootstrapping revealed a slight optimism of the model (of 0.05) and therefore the expected discriminative performance of this model when applied to future patients will be 0.73 . The explained variance $\left(R^{2}\right)$ was $38 \%$. 
Table 5.3 Independent predictors of mortality and scoring rule.

\begin{tabular}{lccrrr}
\hline & $\begin{array}{c}\text { Coefficients } \\
(\beta)\end{array}$ & $\mathrm{HR}$ & $95 \% \mathrm{Cl}$ & $P$-value & Score* \\
\hline Age, per 10 years & 0.368 & 1.44 & $1.04-2.02$ & 0.031 & 4 \\
Male Sex & 1.001 & 2.72 & $1.79-4.13$ & $<0.001$ & 10 \\
Living alone & 0.470 & 1.60 & $1.06-2.42$ & 0.027 & 5 \\
Cardiovascular disease & 0.388 & 1.47 & $1.00-2.17$ & 0.050 & 4 \\
Diabetes & 0.418 & 1.52 & $0.95-2.43$ & 0.081 & 4 \\
Medication no. $\geq 2$ & 0.473 & 1.60 & $0.94-2.43$ & 0.085 & 5 \\
BMI <18.5 kg/m & 1.236 & 3.44 & $1.77-6.70$ & $<0.001$ & 12 \\
EMS score $<20$ & 0.517 & 1.68 & $1.11-2.53$ & 0.014 & 5 \\
Motor deficit in ADL & 0.387 & 1.47 & $0.97-2.34$ & 0.069 & 4 \\
Process deficit in ADL & 0.654 & 1.92 & $1.13-3.26$ & 0.015 & 7 \\
\hline
\end{tabular}

* Score was obtained by multiplying the regression coefficient by 10 rounded to the nearest integer; EMS: elderly mobility score; $\mathrm{ADL}$, activities of daily living; $\mathrm{HR}$, Hazard ratio; $\mathrm{Cl}$, confidence interval. To calculate patient's exact probability of mortality within 3 years, follow the steps below; 1 ) The $\beta$ coefficients are used to compute a linear function $(\mathrm{L}$ ): $\mathrm{L}=0.368 \mathrm{Xage} / 10+1.001$ (if men) +0.470 (if living alone) +0.388 (if positive history of cardiovascular disease) +0.418 (if diabetes) +0.473 (if taking $\geq 2$ medicines) +1.236 (if $\mathrm{BMl}<18.5$ ) + 0.517 (if EMS score $<20$ ) +0.387 (if with motor deficit in ADL) +0.654 (if process deficit in $A D L$ ); 2 ) This function is then evaluated at the mean values for each variable $(M): M=0.368 \times 7.802+1.001 \times 0.379+0.470 \times 0.496+$ $0.388 \times 0.484+0.418 * 0.182+0.473 \times 0.766+1.236 \times 0.182+0.517 \times 0.359+0.387 \times 0.469+0.654 X 0.706=4.995 ; 3)$ The value of $M$ is subtracted from function $L$ to produce function $A$ (i.e. $A=L-M$ ), which is then exponentiated, to produce $B\left(B=\exp ^{A}\right)$, the latter representing thus the relative odds for mortality; 4$)$ The baseline survival value at 3 years $[s(t 3)]$ is then exponentiated by $B$ and subtracted from 1 to calculate the 3 year probability of death, as follows: $P=1-[\mathrm{s}(\mathrm{t})]^{\mathrm{B}}$, where $\mathrm{s}(\mathrm{t} 3)=0.727$. Similarly, the probability of death within 3 years can be estimated on the basis of each patient's risk score by replacing the coefficients by the integer scores provided in the table and following the steps listed above. $P=1-0.727^{\exp [(0.1 \times \text { risk score)-5.313) }}$

Note: with the use of the baseline survival function at 1 year[s(t1) $=0.936]$ and 2 years $[s(t 2)=0.844]$, the probability of death at those time points can be also estimated.

\section{Prognostic Risk Score}

This model was transformed into an easily applicable rule, and a risk score was calculated for each patient, on the basis of the size of the regression coefficients, as follows: age (per 10 years) $* 4+$ male sex*10 + no partner*5 + BMI $<18.5 \mathrm{~kg} / \mathrm{m}^{2} * 12+$ cardiovascular disease $* 4+$ diabetes $* 4+$ no. of drugs $\geq 2 * 5$, EMS $<20 * 5+$ ADL motor deficit*4 + ADL process deficit*7 (Table 5.3). This scoring rule can therefore be used as simple predictor of a patient's mortality risk within 3 years based on his/her characteristics at presentation. The mean value of the risk score observed in this population was 52.7 (inter-quartile range: 46.7-59.5). The AUC of this risk score was similar to that of the original model: 0.78 (95\% Cl: $0.71-0.84)$.

For practical applications aiming at risk stratification, patients were classified into very good (score<45 points), good (score 45-50 points), moderate (score 51-55 points), poor (score 56-61 points) and very poor (score>61 points) prognosis groups, on the basis of the values obtained with the risk score. For example, a hypothetical 70-year old man, who lives alone, has had a myocardial infarction, is currently taking 4 different medications and has shown process deficits in ADL, would receive a score of 
$28+10+5+4+5+7=59$ points, and hence be classified in the "poor prognosis" group. The validity of this classification was confirmed by the high level of agreement between mean predicted 3-year mortality risk and the observed 3-year mortality in each prognostic group (Figure 5.1). In addition, Kaplan-Meier survival curves show that the observed mortality risk is increasing across the 5 risk groups $(P<0.001)$ (Figure 5.2$)$. On the basis of these findings, the use of a cut-off value $\geq 56$ points, may thus be helpful to identify those patients having a 'poor' or 'very poor' prognosis.

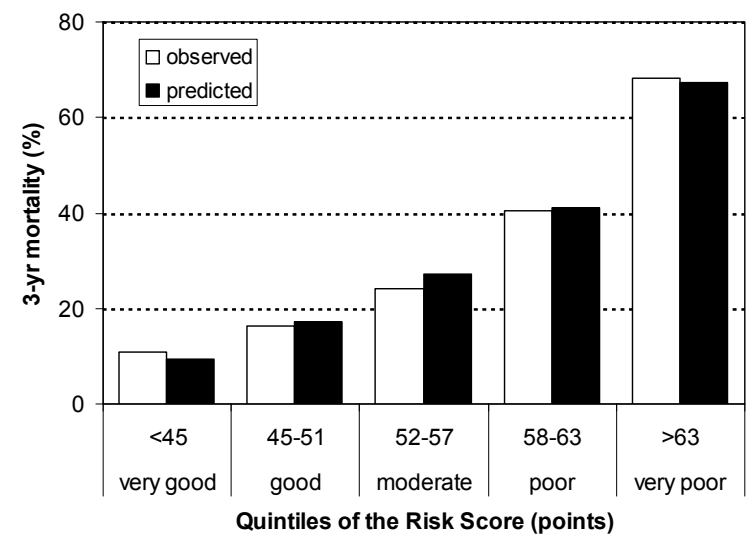

Figure 5.1 Mortality rates at 3 years stratified according to the 5 different risk classification groups.

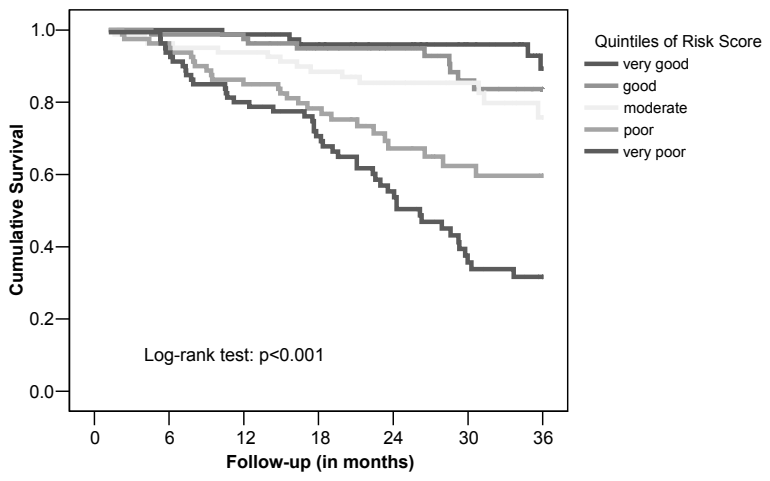

Figure 5.2 Kaplan-Meier curves for 3-year mortality according to the 5 different risk classification groups. 


\section{Discussion}

In this prospective observational study on 401 psychogeriatric (mostly demented) patients we identified older age, male sex, living alone, low BMI, cardiovascular disease, diabetes, polypharmacy, impaired mobility and disabilities in daily activities as the combination of the baseline frailty-related characteristics that best predict incident mortality risk. Based on these readily available characteristics, we developed and validated a simple to use prognostic risk score, which could successfully distinguish psychogeriatric patients according to their different levels of risk, thereby being of great utility to diagnostic and therapeutic decisions in clinical practice.

The construct of 'frailty' denotes a multidimensional syndrome in which loss of reserve capacity results in increased vulnerability. The manifestations of frailty that are most widely accepted are a constellation of symptoms including shrinking and weight loss, weakness and fatigue, inactivity and reduced food intake and signs such as comorbidity, cognitive decline and ADL inactivity and disability., ${ }^{4,73}$ Social circumstances and reduced resources are also thought to be important determinants in the development of frailty

The model described here was developed according to a multidimensional approach, which is deemed as most appropriate in the context of geriatric practice. It comprises a limited number of co-morbid diseases, deficits and practical tests to score the presence of frailty. The variables retained as independent predictors of mortality in our population are found in different combinations in most studies aiming at the identification of frailty in the elderly. Male sex has been associated with a lower survival than female sex ${ }^{24}$, and so is all co-morbidity but especially cardiovascular disease. ${ }^{25,26}$ Physical function impairment and low BMI are also a strong predictor of mortality in the elderly. ${ }^{26-28}$

Operational definitions of frailty are for the most part based on certain rules, for instance if 3 or more symptoms consistent with increased vulnerability (e.g. weight loss, exhaustion, loss of strength, slow walking and low physical activity) are present. ${ }^{6,24,29}$ Counting impairments or accumulated deficits (including symptoms, disabilities and diseases) is another way of defining frailty. These approaches are, however, time consuming and therefore not widely used in daily practice. ${ }^{2,30}$ Clinical judgement on the basis of case history taking and clinical examination is frequently used as an alternative, but is highly dependent on the experience of the observer. ${ }^{2,31}$ The advantage of our approach is its simplicity, objectivity and the ease with which it can be applied in daily practice. More importantly, and from a methodological point of view, we have not just developed a mortality risk model and score but also assessed its validity with measures of discriminative performance, calibration and over-optimism. This complementary range of measures of (internal) validity has not often been presented in the existing literature, making the utility of proposed frailty risk scores in the elderly difficult to judge. 
There are several limitations in our study that warrant mentioning. The population in which the present study was conducted is relatively small and it is a selective. Subjects referred for further examination after identification of combined physical and cognitive problems by their GP. The prevalence of frailty in this older (mostly demented) population is thus likely to be high. Therefore, the extent to which this score can be applied in the general older population can be questioned. However, this was a specific purpose of our study as the risk scores already available were developed in general populations and were therefore not specific enough in our population. For instance, the CSHA Clinical Frailty Scale ${ }^{2}$, when applied to our population showed only a poor-to-moderate discriminative performance: $A U C=0.62(95 \% \mathrm{Cl}: 0.55-0.70)$. We included only community-dwelling psychogeriatric patients and therefore our risk score may not be suitable to institutionalised patients. In addition, only the value of the risk score to predict mortality was investigated. Whether it can also be used to predict other frailty-related end-points such as institutionalisation, falling, fractures and functional decline needs further investigation. The frailty markers investigated herein were determined at baseline only. No follow-up measurement of variables was done to estimate the dynamic process of frailty and its impact on morbidity and mortality. In a dynamic approach to define frailty female sex is an independent predictor for mortality. ${ }^{24}$ Men seem overall to die more suddenly whereas women collect disabilities. Comparative studies are needed to substantiate which approach contributes best to the recognition of frailty and the optimising of care to elderly people. The risk score discriminated satisfactorily those with poor from those with relatively good prognosis even after internal validation (i.e. bootstrapping). We are therefore also confident that the score will perform well in future patients. However, further external validation (e.g. in other regions/countries and/or future cohorts) is obviously required.

In conclusion, we developed and validated a frailty risk score based on relatively simple and easily obtained variables that can be used to distinguish psychogeriatric patients according to their levels of mortality risk and therefore help decisions on diagnostic and therapeutic procedures in clinical practice. 


\section{References}

1. Fried LP, Walston J. Frailty and failure to thrive. In: Hazzard WR, Blass JP, Halter JB, Ouslander JG, Tinetti ME, eds. Principles of geriatric medicine \& gerontology. New York: McGraw-Hill, 2003: 1487-502.

2. Rockwood K, Song X, MacKnight C, Bergman H, Hogan DB, McDowell I, Mitnitski A. A global clinical measure of fitness and frailty in elderly people. CMAJ 2005;173:489-95.

3. Fried LP, Tangen CM, Walston J, Newman AB, Hirsch C, Gottdiener J, Seeman T, Tracy R, Kop WJ, Burke G, McBurnie MA; Cardiovascular Health Study Collaborative Research Group. Frailty in older adults: evidence for a phenotype. J Gerontol A Biol Sci Med Sci 2001;56:M146-56.

4. Chin A Paw MJ, Dekker JM, Feskens EJ, Schouten EG, Kromhout D. How to select a frail elderly population? A comparison of three working definitions. J Clin Epidemiol 1999;52:1015-21.

5. Jones D, Song X, Mitnitski A, Rockwood K. Evaluation of a frailty index based on a comprehensive geriatric assessment in a population based study of elderly Canadians. Aging Clin Exp Res 2005;17: 465-71.

6. Puts MT, Lips P, Deeg DJ. Static and dynamic measures of frailty predicted decline in performancebased and self-reported physical functioning. J Clin Epidemiol 2005;58:1188-98.

7. Rockwood K, Stadnyk K, MacKnight C, McDowell I, Hébert R, Hogan DB. A brief clinical instrument to classify frailty in elderly people. Lancet 1999;353:205-6.

8. Wolfs CA, Verhey FR, Kessels A, Winkens RA, Severens JL, Dirksen CD. GP concordance with advice for treatment following a multidisciplinary psychogeriatric assessment. Int J Geriatr Psychiatry 2007;22:233-40.

9. American Psychiatric Association. Diagnostic and statistical manual of mental disorders. Washington, DC: American Psychiatric Association, 1994.

10. Sergi G, Perissinotto E, Pisent C, Buja A, Maggi S, Coin A, Grigoletto F, Enzi G; ILSA Working Group. An adequate threshold for body mass index to detect underweight condition in elderly persons: the Italian Longitudinal Study on Aging (ILSA). J Gerontol A Biol Sci Med Sci 2005;60:866-71.

11. Cigolle CT, Langa KM, Kabeto MU, Tian Z, Blaum CS. Geriatric conditions and disability: the Health and Retirement Study. Ann Intern Med 2007;147:156-64.

12. Miles TP, Palmer RF, Espino DV, Mouton CP, Lichtenstein MJ, Markides KS. New-onset incontinence and markers of frailty: data from the Hispanic Established Populations for Epidemiologic Studies of the Elderly. J Gerontol A Biol Sci Med Sci 2001;56:M19-24.

13. D'Hoore W, Bouckaert A, Tilquin C. Practical considerations on the use of the Charlson comorbidity index with administrative data bases. J Clin Epidemiol 1996;49:1429-33.

14. Cockcroft DW, Gault MH. Prediction of creatinine clearance from serum creatinine. Nephron 1976;16:31-41.

15. Kamphuis JS, Salden HJ, Zuijderhoudt FM. Albumine-analyse in plasma: vergelijking tussen broomcresolgroen, broomcresolpurper en een immunoassay bij volwassen patienten met en zonder hemodialyse. Ned Tijdschr Klin Chem 2001;26:9-12.

16. Spilg EG, Martin BJ, Mitchell SL, Aitchison TC. A comparison of mobility assessments in a geriatric day hospital. Clin Rehabil 2001;15:296-300.

17. Kirkley KN, Fisher AG. Alternate forms reliability of the assessment of motor and process skills. J Outcome Meas 1999;3:53-70.

18. Folstein MF, Folstein SE, McHugh PR. "Mini-mental state". A practical method for grading the cognitive state of patients for the clinician. J Psychiatr Res 1975;12:189-98.

19. van Buuren S, Boshuizen HC, Knook DL. Multiple imputation of missing blood pressure covariates in survival analysis. Stat Med 1999;18:681-94.

20. Heagerty PJ, Lumley T, Pepe MS. Time-dependent ROC curves for censored survival data and a diagnostic marker. Biometrics 2000;56:337-44.

21. Harrell FE Jr, Lee KL, Mark DB. Multivariable prognostic models: issues in developing models, evaluating assumptions and adequacy, and measuring and reducing errors. Stat Med 1996;15:361-87.

22. Royston P. Explained variation for survival models. Stata Journal 2006;6:83-96.

23. Mitnitski AB, Graham JE, Mogilner AJ, Rockwood K. Frailty, fitness and late-life mortality in relation to chronological and biological age. BMC Geriatr 2002;2:1. 
24. Puts MT, Lips P, Deeg DJ. Sex differences in the risk of frailty for mortality independent of disability and chronic diseases. J Am Geriatr Soc 2005;53:40-7.

25. Rockwood K. Long term risks of death and institutionalisation of elderly people in relation to deficit accumulation at age 70. J Am Geriatr Soc 2006;54:975-9.

26. Ravaglia G, Forti P, Lucicesare A, Pisacane N, Rietti E, Patterson C. Development of an easy prognostic score for frailty outcomes in the aged. Age Ageing 2008;37:161-6.

27. Purser JL, Kuchibhatla MN. Identifying frailty in hospitalized older adults with significant coronary artery disease. J Am Geriatr Soc 2006;54:1674-81.

28. Rockwood K. Failure to complete performance based measures is associated with poor health status and an increased risk of death. Age Ageing 2007;36:225-8.

29. Klein BE, Klein R, Knudtson MD, Lee KE. Frailty, morbidity and survival. Arch Gerontol Geriatr 2005;41:141-9.

30. Mitnitski A, Song X, Skoog I, Broe GA, Cox JL, Grunfeld E, Rockwood K. Relative fitness and frailty of elderly men and women in developed countries and their relationship with mortality. J Am Geriatr Soc 2005;53:2184-9.

31. Studenski S, Hayes RP, Leibowitz RQ, Bode R, Lavery L, Walston J, Duncan P, Perera S. Clinical Global Impression of Change in Physical Frailty: development of a measure based on clinical judgment. J Am Geriatr Soc 2004;52:1560-6. 


\section{Chapter 6}

\section{The frailty dilemma}

Review of the predictive accuracy of major frailty scores

E Pijpers, I Ferreira, CDA Stehouwer, AC Nieuwenhuijzen Kruseman Accepted European Journal of Internal Medicine 2 Sept 2011 (on line available) 


\section{Abstract}

\section{Background}

To identify frail elderly individuals, several index or scoring systems have been developed for research purposes. The practical value of these scores for screening and diagnostic use is uncertain.

\section{Aim}

The available scoring systems were reviewed to determine whether they can be used in daily practice.

\section{Methods}

Literature study on relevant test instruments developed for the detection of frailty on the basis of theoretical views on the frailty concept. Data on sensitivity and specificity and predictive values were extracted.

\section{Results}

Several $(n=6)$ frailty scores were described with respect to their value as a screening or diagnostic test. Outcome of the selected test instruments is presented as a risk of negative health outcome when a test is positive. The reported AUCs of ROCs varied from 0.55 for functional decline in people admitted to an accident and emergency department to 0.87 for prediction of mortality on the basis of a co-morbidity score. As the prevalence of frailty and resulting negative health outcomes in published reports was low (5-41\%), presented sensitivity and specificity values lead to low positive predictive values (6-49\%) but reasonable negative predictive values (73-96\%).

\section{Conclusions}

As the number of false positive values of most available tests is substantial, these frailty scores are of limited value for both screening and diagnostic purposes in daily practice. As diagnostic instruments they can best be used to exclude frailty. The falsepositive rate of currently available tests is too high to allow major decisions on medical care to be made on the basis of a positive test. 


\section{Introduction}

A substantial number of people over the age of 65 years are considered frail. The percentages reported vary between 10 and $20 \%$ at the age of 65 years increasing to $45 \%$ over the age of 85 years. ${ }^{1,2}$

In the Netherlands, over the age of 65 years the number of people with two or more chronic diseases is approximately $60 \%$. Twelve percent of people over the age of 65 years need a hospital admission in a given year, which is twice the number of hospital admissions reported for people below the age of 65 years. The average length of stay in a hospital over the age of 65 years is 12.6 days, compared to 6.4 days below the age of 65 years. The percentage of hospital beds occupied by people over the age of 65 years numbers $45 \%{ }^{3}$ Hence, a small but increasing number of frail older people affected by multiple chronic diseases and functional limitations accounts for most of the excess cost both in resources and health care spending. ${ }^{4}$

Frailty is a consequence of biological changes related to aging and the occurrence of one or more chronic conditions and their complications including functional impairment. The chronic conditions most frequently associated with frailty are heart failure, renal impairment, stroke, osteoarthritis of hip and knee, and depression. ${ }^{5-7}$ Frailty, chronic diseases and disability overlap but they are seen as distinct clinical entities. ${ }^{18}$ A consensus conference defined frailty as "a state of increased vulnerability to stressors due to age-related decline in physiologic reserve across neuromuscular, metabolic, and immune systems". ${ }^{9}$ Although more research into the physiologic basis of frailty is needed to clarify processes that contribute to frailty, many operational definitions of frailty include alterations in mobility, strength, endurance, nutrition, and physical activity. ${ }^{1,10-12}$ Presence of cognitive impairment increases the likelihood of adverse outcomes in older patients who meet criteria for physical frailty; however, most definitions of frailty do not incorporate cognitive assessment. ${ }^{13}$ Despite the uncertain definition of frailty it is generally accepted to be a pre-disability state with the potential for intervention.

Frail individuals are at high risk for dependency, institutionalization, falls, injuries, hospitalization, slow recovery from any illness and mortality. They are therefore most in need of health care and community and informal support services.

In order to identify individuals at risk for frailty, several indices have been developed for research purposes. These scores integrate demographic, medical, social and functional information to predict frailty. While criteria for the diagnosis of frailty are still being investigated and discussed, the screening of elderly people for frailty on the basis of the available frailty scores is becoming more and more common practice. In the present review we describe the currently available scoring systems with respect to their predictive values in the general population. 


\section{Methods}

A literature search was performed for articles published in clinical journals published from the start date of the databases used until December 2010. The systematic literature search was performed in the bibliographic databases Pubmed $n=54$ ), EMBASE and Cochrane $(n=363)$. The following search terms were used to search for measurement instruments: assessment, outcome assessment, outcome measure and frail elderly. We found 417 potentially relevant articles. Reading the abstract and if needed the full text article identified relevant articles. We also used references to frailty scores out of the selected articles. The frailty scores were assessed and the predictive ability of these scores was compared to the predictive ability of the Charlson index and the cumulative illness rating scale, two well known co-morbidity indices validated in the older population.

Criteria for the selection of relevant studies were

- $\quad$ Representation of major theoretical views ${ }^{1,14-18}$ on the development of the frailty phenotype.

- $\quad$ Presentation of an area under the curve (AUC) for major health outcomes.

Five of the thus selected scores presented information on sensitivity and specificity and predictive values for relevant frailty-related negative health outcomes. The 5 scores thus identified were examined for their use in a screening for frailty and diagnosing frailty in the general population.

\section{Results}

\section{a. Value of the instruments used to screen for frailty}

Several frailty scores based on different perspectives on the frailty concept have been developed to screen populations of elderly people for research purposes (Table 6.1). These scores mostly involve a combination of age and major risk factors for vulnerability. They describe frailty 1 ) as resulting from the burden of multiple diseases and disabilities; 2 ) as a distinct biological entity resulting in a frailty phenotype; and 3) by the selection of vulnerable elderly people who are evaluated for the allocation of medical treatment and care. These scores were developed in populations varying from community-dwelling people, to people in primary care contacts or out-patients clinics and patients seen in hospital settings. The age groups selected vary from all ages for co-morbidity scores to ages over 69 years old. Most scores have been developed in prospective studies using up to nine domains of frailty or multiple selections of comorbid conditions. The negative health outcomes in these scores varies from death to institutionalization, falling, fractures or (re)hospitalization. Time of follow-up is short in studies done in hospital emergency departments, to more than 120 months in community studies. Outcomes were presented as risk of a negative health outcome 
when the test is positive. The reported areas under the receiver operated characteristic curve (AUCs) varied from 0.55 - 0.65 for functional decline determined in a population admitted to an accident and emergency department to $0.58-0.87$ (Table 6.1) in hospitalized patients to predict mortality following a score based on comorbidity. The predictive value of an AUC of 0.55 is comparable to guessing, whereas the predictive value of an AUC of 0.87 is qualified as:"good".

The presented scores show that the prevalence of frailty and resulting negative health outcomes were relatively low, resulting in low positive predictive values (Table 6.2). Lowering the threshold of the frailty score improves sensitivity, with consequently loss of specificity, and a further lowering of the positive predictive value. Consideration of the tests in Table 6.2 with a view to using multiple tests to improve the sensitivity suggests that such a strategy will not be successful, as they all use similar domains of frailty.

\section{b. Value of instruments used to diagnose frailty}

The tests shown in both Table 6.1 and Table 6.2 are not specific enough to diagnose frailty accurately as expressed by the area under the curve of the best score. Increasing the threshold of the instruments for the diagnosis of frailty will improve specificity of the test but probably excludes elderly people in an early phase of the development of frailty. Consideration of the tests in Table 6.2 with a view to serial testing to improve specificity again suggests that such a strategy will not be successful, as they all use similar domains of frailty.

\section{Discussion}

This paper discusses the concept of frailty and frailty scores derived from models of frailty based on theoretical views. The aim of this paper was to study whether these frailty scores are sensitive and specific enough to identify frail people and hence can be used for diagnostic and therapeutic decisions in daily practice. Our conclusion is that the available scores can be used to make frailty unlikely but are of limited value to identify frail people, i.e. that a positive test result is of uncertain value.

The aim of screening for frailty in elderly people may be considered to be to identify people in a relatively early phase, with no or limited frailty-related complaints, at a point in time at which interventions are still effective. Screening is only useful if the frailty risk can be reversed or negative health outcomes avoided. Equally important is the ability to prevent unnecessary suffering as a consequence of futile medical interventions. 


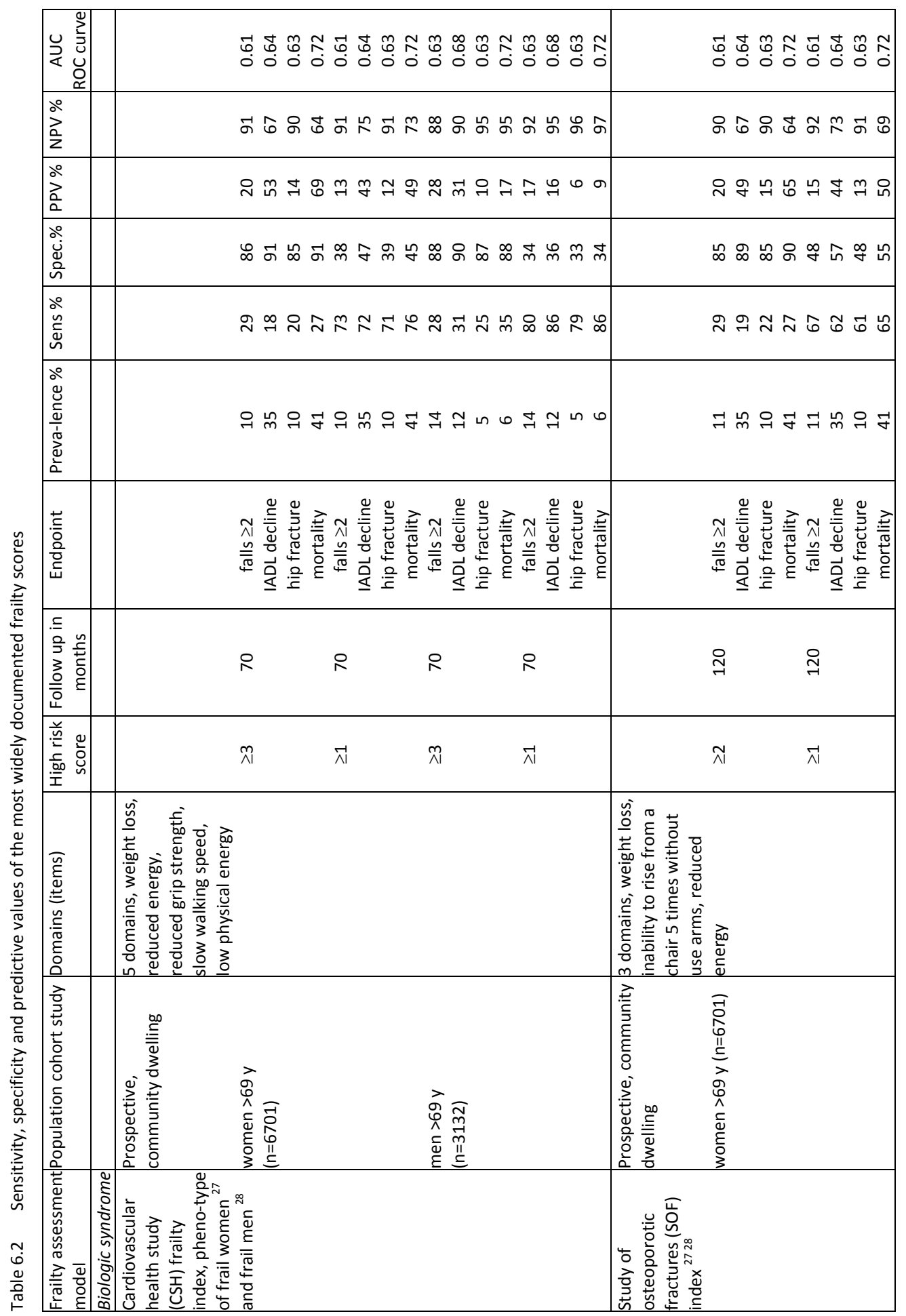




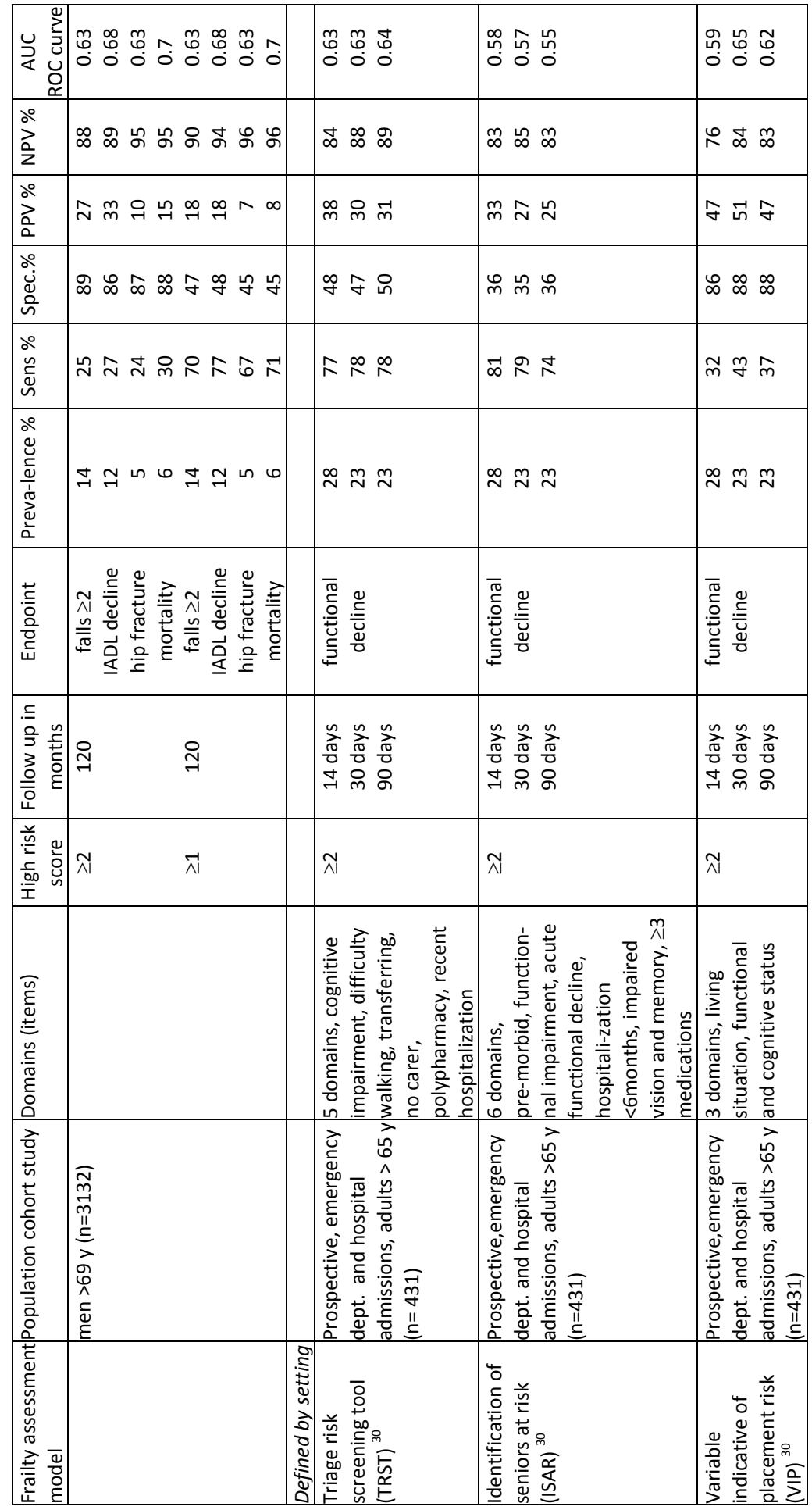


Reasons for the disappointing results of the described frailty scores can be explained as follows:

Firstly: the concept of frailty is based on a composite of different and debatable markers and not on a complex of symptoms or a clinical condition that fulfils the criteria for effective screening formulated by Wilson and Jungner. ${ }^{18}$

These criteria state that:

- The disease or condition is a prevalent, serious health problem;

- The natural course of the disease is known;

- There is a pre-clinical (or window) phase in which to diagnose the disease;

- Treatment is available to improve the prognosis;

- There are tests to find the disease in the asymptomatic phase;

- Costs for screening, case finding, treatment and care are reasonable.

Although frailty is a prevalent age-related condition, the other requirements for screening for frailty are uncertain or not fulfilled.

Secondly: It is unclear which population should be screened or followed up in these scores. There are several possible screening scenarios for individuals at risk for frailty. These involve: population screening, opportunistic screening and stepwise screening. ${ }^{1,19-21}$

Population screening with age as a major frailty risk factor involves regular screening of all individuals when they reach a certain age. Decline of physiologic function starts in the fourth decade, but rapid decline of physiologic characteristics occurs after the age of 70 years. ${ }^{15}$ Hence, screening for frailty on the basis of age is reasonable in view of the nature of the frailty process. ${ }^{22}$ However, if age is used as a risk factor and all people who reach middle age are selected for frailty screening, the population to be (repeatedly) screened will be considerable, as will be the consequent cost to society. Although at the age of 65 years 7 to $20 \%$ of the population is already estimated to be frail, many studies target individuals over the age of 70 years for screening, in view of the rapid progression of frailty hereafter.

Opportunistic screening would involve screening for frailty in every elderly patient consulting the general practitioner or admitted to an emergency setting for complaints that may be frailty related. A number of frail elderly people will be missed in this scenario as it is dependent on the need for a consultation. However, more than $90 \%$ of people aged 65 and older have at least one contact with their general practitioner every year, with an average of more than 10 contacts every year over the age of 75 years. $^{23}$ Moreover a the application of the Fried criteria to every patient over the age of 75 years coming to the practitioners office has been proved possible. ${ }^{24}$

Stepwise screening could be done with multi-morbidity or disabilities as a determining factor for frailty. For multi-morbidity this would mean regular screening of all elderly individuals in a population with two or more chronic conditions. For physicians, the presence of these conditions is easy to identify, limits the number of individuals to be screened and seems a logical choice. However, a survey of people with multi-morbidity over the age of 70 years yielded only slightly higher rates of new confinement to bed 
or chair than rates found in people without multi-morbidity (24 versus $17 \%$ ). ${ }^{25}$ Therefore, having a number of these co-morbid conditions does not strongly predict loss of independence. On the other hand, most frail people do have chronic diseases, and there is a significant trend of increasing prevalence of frailty in persons with more diseases. ${ }^{5,7}$ This means that if multi-morbidity is used as a criterion for frailty screening, it is not the existence of multiple chronic conditions as such, but rather the severity of these conditions that is relevant. Consequently, the severity of the chronic conditions selected has to be taken into account for the screening for frailty. This makes this approach difficult to apply.

Another example of stepwise screening would be to use the presence of one or more functional disabilities as main frailty risk factor. This means that many otherwise healthy non-frail individuals of any age are included. This problem can be overcome by selecting institutionalized disabled persons only, but then many non-institutionalized frail people will be missed.

Therefore the most sensible strategy thus far may be population screening above the age of 70 years. The selected group of individuals will contain both individuals with and without co-morbidity and both institutionalized and community-dwelling individuals. The value of this approach is dependent on the use of a test instrument sensitive enough to detect as many people that are affected as possible, but not necessarily as specific to exclude those people that are not. On the other hand, low specificity is certainly not without problems as false-positive test results may lead to stigmatization of people as frail when they are not, with the attendant risk of underutilization of diagnostic and therapeutic possibilities.

Thirdly: with respect to the diagnostic performance of the frailty score, one would like to have several time points at which the score is taken (although the time points at which to repeat the score are unclear). The diagnostic performance of any given frailty score would improve with repeat scores, and more insight as to the development of the frailty process would be gained. Frailty is sometimes described as a reversible process and its clinical development is not clear.

Fourthly: There is no "gold standard" frailty test to compare screening or diagnostic instruments to and the best instruments do not perform much better than the judgment of an experienced physician (as seen in a score based on pattern recognition: e.g. $\mathrm{CSH}$ in Table 5.1). ${ }^{26}$

In conclusion, our review of screening instruments for frailty shows that these tests are not sensitive enough for screening and diagnostic purposes. The data show that these tests can rather be used to exclude than to identify frail people. Selecting only the most frail individuals in a population by raising the threshold of the scores described may however be selecting a population in which interventions are no longer feasible. Consequently, a public policy of repeatedly testing all individuals at a certain age for the presence of frailty with the available instruments and subsequently making decisions on individual medical treatment and/or availability of social support may be expensive, ineffective and thus not justified as yet. 


\section{Learning points}

Frailty is a challenge for healthcare professionals.

The screening instruments for frailty presently available are not sensitive enough for screening and diagnosing frailty.

Population screening with these instruments for the purpose of making individual medical decisions is at present not justified. 


\section{References}

1. Fried LP, Tangen CM, Walston J, Newman AB, Hirsch C, Gottdiener J, Seeman T, Tracy R, Kop WJ, Burke G, McBurnie MA; Cardiovascular Health Study Collaborative Research Group. Frailty in older adults: evidence for a phenotype. J Gerontol A Biol Sci Med Sci 2001;56:M146-56.

2. Fried LP, Walston J. Frailty and Failure to Thrive. In: Hazzard WR, Blass JP, Halter JB, Ouslander JG, Tinetti ME, eds. Principles of Geriatric Medicine \& Gerontology. 5th ed. New York: McGraw-Hill Companies, Inc. 2003:1487-502.

3. Statistiek CBvd. Gezondheid en zorg in cijfers 2009.

4. Meerding WJ, Bonneux L, Polder JJ, Koopmanschap MA, van der Maas PJ. Demographic and epidemiological determinants of healthcare costs in Netherlands: cost of illness study. BMJ 1998;317: 111-5.

5. Fried LF, Katz R, Sarnak MJ, Shlipak MG, Chaves PH, Jenny NS, Stehman-Breen C, Gillen D, Bleyer AJ, Hirsch C, Siscovick D, Newman AB. Kidney function as a predictor of noncardiovascular mortality. J Am Soc Nephrol 2005;16:3728-35.

6. Shlipak MG, Stehman-Breen C, Fried LF, Song X, Siscovick D, Fried LP, Psaty BM, Newman AB. The presence of frailty in elderly persons with chronic renal insufficiency. Am J Kidney Dis 2004;43:861-7.

7. Newman AB, Gottdiener JS, Mcburnie MA, Hirsch CH, Kop WJ, Tracy R, Walston JD, Fried LP; Cardiovascular Health Study Research Group. Associations of subclinical cardiovascular disease with frailty. J Gerontol A Biol Sci Med Sci 2001;56:M158-66.

8. Walston J, Hadley EC, Ferrucci L, Guralnik JM, Newman AB, Studenski SA, Ershler WB, Harris T, Fried LP. Research agenda for frailty in older adults: toward a better understanding of physiology and etiology: summary from the American Geriatrics Society/National Institute on Aging Research Conference on Frailty in Older Adults. J Am Geriatr Soc 2006;54:991-1001.

9. Ferrucci L, Guralnik JM, Studenski S, Fried LP, Cutler GB, Jr., Walston JD. Designing randomized, controlled trials aimed at preventing or delaying functional decline and disability in frail, older persons: a consensus report. J Am Geriatr Soc 2004;52:625-34.

10. Chin APMJ, Dekker JM, Feskens EJ, Schouten EG, Kromhout D. How to select a frail elderly population? A comparison of three working definitions. J Clin Epidemiol 1999;52:1015-21.

11. Cigolle CT, Langa KM, Kabeto MU, Tian Z, Blaum CS. Geriatric conditions and disability: the Health and Retirement Study. Ann Intern Med 2007;147:156-64.

12. Avila-Funes JA, Amieva H, Barberger-Gateau P, Le Goff M, Raoux N, Ritchie K, Carrière I, Tavernier B, Tzourio C, Gutiérrez-Robledo LM, Dartigues JF. Cognitive impairment improves the predictive validity of the phenotype of frailty for adverse health outcomes: the three-city study. J Am Geriatr Soc 2009; 57:453-61.

13. Mitnitski AB, Mogilner AJ, MacKnight C, Rockwood K. The accumulation of deficits with age and possible invariants of aging. ScientificWorldJournal 2002;2:1816-22.

14. Studenski S, Hayes RP, Leibowitz RQ, Bode R, Lavery L, Walston J, Duncan P, Perera S. Clinical Global Impression of Change in Physical Frailty: development of a measure based on clinical judgment. J Am Geriatr Soc 2004;52:1560-6.

15. Bortz WM, 2nd. The physics of frailty. J Am Geriatr Soc 1993;41:1004-8.

16. Linn BS, Linn MW, Gurel L. Cumulative illness rating scale. J Am Geriatr Soc 1968;16:622-6.

17. Rockwood K, Jones D, Wang Y, Carver D, Mitnitski A. Failure to complete performance-based measures is associated with poor health status and an increased risk of death. Age Ageing 2007;36:225-8.

18. Wilson JM, Jungner YG. [Principles and practice of mass screening for disease]. Bol Oficina Sanit Panam 1968;65:281-393.

19. Winograd CH. Mental status tests and the capacity for self-care. J Am Geriatr Soc 1984;32:49-55.

20. Sui X, Laditka JN, Hardin JW, Blair SN. Estimated functional capacity predicts mortality in older adults. J Am Geriatr Soc 2007;55:1940-7.

21. Winograd $\mathrm{CH}$, Gerety MB, Chung M, Goldstein MK, Dominguez F, Jr., Vallone R. Screening for frailty: criteria and predictors of outcomes. J Am Geriatr Soc 1991;39:778-84.

22. Puts MT, Lips P, Deeg DJ. Static and dynamic measures of frailty predicted decline in performancebased and self-reported physical functioning. J Clin Epidemiol 2005;58:1188-98. 
23. Vaes B, Pasquet A, Wallemacq P, Rezzoug N, Mekouar H, Olivier PA, Legrand D, Matheï C, Van Pottelbergh G, Degryse J. The BELFRAIL (BFC80+) study: a population-based prospective cohort study of the very elderly in Belgium. BMC Geriatr 2010;10:39.

24. Drey M, Wehr H, Wehr G, Uter W, Lang F, Rupprecht R, Sieber CC, Bauer JM. The frailty syndrome in general practitioner care : A pilot study. Z Gerontol Geriatr. 2011;44:48-54.

25. Clark LP, Dion DM, Barker WH. Taking to bed. Rapid functional decline in an independently mobile older population living in an intermediate-care facility. J Am Geriatr Soc 1990;38:967-72.

26. Rockwood K, Stadnyk K, MacKnight C, McDowell I, Hebert R, Hogan DB. A brief clinical instrument to classify frailty in elderly people. Lancet 1999;353:205-6.

27. Charlson ME, Pompei $\mathrm{P}$, Ales KL, MacKenzie CR. A new method of classifying prognostic comorbidity in longitudinal studies: development and validation. J Chronic Dis 1987;40:373-83.

28. Perkins AJ, Kroenke K, Unützer J, Katon W, Williams JW, Hope C, Callahan CM. Common comorbidity scales were similar in their ability to predict health care costs and mortality. J Clin Epidemiol 2004;57:1040-8.

29. Rockwood K, Song X, MacKnight C, Bergman H, Hogan DB, McDowell I, Mitnitski A. A global clinical measure of fitness and frailty in elderly people. CMAJ 2005;173:489-95.

30. Conwell Y, Forbes NT, Cox C, Caine ED. Validation of a measure of physical illness burden at autopsy: the Cumulative IIIness Rating Scale. J Am Geriatr Soc 1993;41:38-41.

31. Folstein MF, Folstein SE, McHugh PR. "Mini-mental state". A practical method for grading the cognitive state of patients for the clinician. J Psychiatr Res 1975;12:189-98.

32. Teng EL, Chui HC. The Modified Mini-Mental State (3MS) examination. J Clin Psychiatry 1987;48:314-8.

33. Ensrud KE, Ewing SK, Taylor BC, Fink HA, Cawthon PM, Stone KL, Hillier TA, Cauley JA, Hochberg MC, Rodondi N, Tracy JK, Cummings SR. Comparison of 2 frailty indexes for prediction of falls, disability, fractures, and death in older women. Arch Intern Med 2008;168:382-9.

34. Ensrud KE, Ewing SK, Cawthon PM, Fink HA, Taylor BC, Cauley JA, Dam TT, Marshall LM, Orwoll ES, Cummings SR; Osteoporotic Fractures in Men Research Group. A comparison of frailty indexes for the prediction of falls, disability, fractures, and mortality in older men. J Am Geriatr Soc 2009;57:492-8.

35. Pijpers E, Ferreira I, van de Laar RJ, Stehouwer CD, Nieuwenhuijzen Kruseman AC. Predicting mortality of psychogeriatric patients: a simple prognostic frailty risk score. Postgrad Med J 2009;85:464-9.

36. Braes T, Flamaing J, Sterckx W, Lipkens P, Sabbe M, de Rooij SE, Schuurmans MJ, Moons P, Milisen K. Predicting the risk of functional decline in older patients admitted to the hospital: a comparison of three screening instruments. Age Ageing 2009;38:600-3. 


\section{Chapter 7}

General discussion 
Chapter 7 


\section{Introduction}

The main objective of this thesis was to gain insight into the complex relationship between co-morbidity, functional limitations and frailty leading to mortality in older people.

The specific research questions we asked were:

1. What is the prevalence of complicating and concurrent morbidities in older patients with diabetes mellitus?

2. To what extent does the occurrence of co morbidity affect the burden of disease in older patients with diabetes mellitus, and their use of medical healthcare?

3. Does the clustering of complicating and concurrent morbidity in diabetes patients over the age of 65 years lead to serious functional limitations such as recurrent falling?

4. Frailty and mortality in psycho-geriatric patients are hard to predict but important in counseling and therapeutic decision making. Can a simple prognostic frailty risk score be developed and validated in psycho-geriatric patients?

5. Can any of the presently available frailty scoring systems be used in daily practice, for the purpose of distinguishing low- from high-risk elderly patients?

In the first part of the thesis we looked at co-morbidity in older patients with the chronic disease diabetes mellitus. In a cohort of older patients with diabetes mellitus the prevalence of co-morbidity and the secondary burden of disease were evaluated, and so was the use of medical health care. In addition, we looked at the risk of frequent falling as a measure of functional limitations in a different cohort of older patients with diabetes mellitus.

In the second part of the thesis, parameters of frailty mentioned in literature such as age, a low body weight, co-morbidity and functional limitations were used to create a simple prognostic frailty score to predict mortality in psychogeriatric patients. The score that was developed was then compared to several scores and indices that were developed in the general older population for research purposes. The question whether any of the available scoring systems can be used in daily practice to distinguish low from high risk older patients was discussed.

\section{Results}

In chapter $\mathbf{3}$ is described that co-morbidity, both complicating (as a consequence of the diabetes) and concurrent (unrelated to the diabetes), occurred very frequently in the older individuals with diabetes we examined. All our patients had at least one comorbid condition and $80 \%$ had both concurrent and complicating co-morbidity. Similar 
findings were reported in literature on older patients with other chronic conditions such as chronic obstructive pulmonary disease, heart failure, cancer and rheumatoid arthritis. ${ }^{1}$ The high numbers of co-morbid conditions we found in older people with diabetes were seen irrespective whether these patients were treated by their general practitioner, a specialist nurse or an endocrinologist.

The extent of co-morbidity unrelated to diabetes (concurrent) was similar in all three subgroups, although the severity of the unrelated co-morbidity was higher in the patients seen by the endocrinologist. The co-morbidity as a consequence of the diabetes (complicating) was higher in the group of patients managed by the endocrinologist. The patients managed by the endocrinologist used more medication, had worse metabolic control in spite of the use of insulin, had a higher mortality risk and needed more other medical specialist care. They were therefore clearly more severely ill and more complex to manage than the patients treated by the general practitioner and the specialist nurse.

Our study therefore showed that the substitution of care and the graded system of care (general practice, specialist nursing care and endocrinologist) we use in Maastricht are both feasible and useful in older people with diabetes. The patients seen by the general practitioner, the nursing specialist and the endocrinologist show increasing complexity and burden of disease. This means that our diabetic patients are getting the right level of care for the complexity of their condition and co-morbidity.

Our study also showed that in spite of the substitution of care in older patients with diabetes in Maastricht the use of healthcare facilities by these patients is substantial. Patients treated by the endocrinologist visited the hospital for specialist consultation on average once a month. The visits to the general practitioner or visits to the outpatients clinic for laboratory tests were not even included in this number of visits. Patients treated by the general practitioner and specialist nurse also showed a high use of health care facilities, although lower than the patients seen by the endocrinologist. This can partly be explained by differences in number of complications. On the other hand, it may be possible that the generalist approach of general practitioners and specialist nurses contributed to less consultations and practice visits. Anyway, in all groups, the high use of health care facilities indicates a substantial burden of disease and burden of care in older patients with diabetes.

In chapter 4 we looked at the risk of frequent falling as a measure of functional limitations in a cohort of older patients with diabetes mellitus of the Longitudinal Ageing Study Amsterdam (LASA). We examined the association between diabetes and incident falls in community dwelling older individuals. We showed that older individuals with diabetes, both male and female, had a $67 \%$ higher risk of recurrent falling than individuals of the same age without diabetes. Factors partly explaining this increased risk were diabetes related polypharmacy (but not the use of any specific medication), the presence of musculoskeletal pain, a poor self perceived health and lower levels of physical activity, lower level of muscular strength, limitations in 
activities of daily life (ADL) an impaired physical performance (including gait and balance) and cognitive impairment.

The number of fractures in our study population did not allow us to evaluate the differences in injurious falls and fracture risk between the older individuals with and without diabetes. Although we could explain the increased risk of recurrent falling in older patients with diabetes in part only, our findings do support the need for an active lifestyle combined with fall prevention efforts in older patients with diabetes to address some of the reversible fall risk factors we found.

In chapter $\mathbf{5}$ we looked at a group of psycho-geriatric patients. We described how parameters of frailty such as a higher age, a low body weight, co-morbidity and functional limitations mentioned in literature, were used to create a simple prognostic frailty score to predict mortality especially in these patients. This was done because frail older individuals are at high risk for dependency, institutionalization, falling, injuries and slow recovery from any illness and mortality when hospitalized for acute illness.

The score we developed was based on the characteristics age, male sex, living alone, a low Body Mass Index (BMI $<18.5 \mathrm{~kg} / \mathrm{m}^{2}$ ) the presence of cardiovascular disease or diabetes, the use of 2 or more medicines, an elderly mobility score below 20 points and deficits in activities of daily life motor and process skills. The area under the curve of this model for the prediction of 3 year mortality risk in our psycho-geriatric patients was $0.78(95 \% \mathrm{Cl} 0.71-0.84)$ indicating a good discriminative performance. The internal validity of the score was assessed with measures of discriminative performance, calibration and over-optimism. Although the results of the internal calibration still showed a predictive value with an area under the curve of 0.73 , external validation is required to further evaluate the model. Furthermore the score was developed in (and for) psycho-geriatric patients and therefore results can not be generalized to the whole population of older individuals. Our score was developed with mortality as the endpoint and thus may not predict other frailty related negative health outcomes such as falling, fractures, hospitalization and need for institutionalization. Although the predictive value of our score is very reasonable for discrimination of mortality risk in a group of psycho-geriatric patients the results are not good enough to base major medical decisions on the outcome of the score in an individual patient.

In chapter $\mathbf{6}$ we looked at the frailty concept as a whole and at several selected frailty scores derived from models of frailty based on theoretical views of frailty. We concluded that the frailty concept is a difficult one, as it is based on a composite of different and debatable markers and not on a clinical condition that fulfills the criteria for effective screening. The frailty scores in literature were developed as research tools. As an instrument of screening or as a basis for individual decision making their performance is disappointing. These instruments are not sensitive enough for screening and diagnosing frailty. The instruments presently available are not suited for 
the purpose of differentiating between the frail individual and the non-frail; therefore we proposed not to make use of the concept in daily practice but to reserve the use for research purposes only.

In this final chapter the results of the individual studies will be placed in a broader perspective focusing on three major topics;

1. The prevalence of chronic disease and multimorbidity in older people and the resulting burden of disease;

2. Functional impairment as a result of chronic disease and multi-morbidity and the possibility to prevent disability;

3. Frailty screening and possible alternatives to assess older individuals at risk for negative health outcomes.

\section{The prevalence of the combination of chronic disease and multimorbidity in older people and the resulting burden of disease}

Individual chronic diseases are complicated by the frequent presence of multimorbidity in older people. Major chronic diseases like diabetes mellitus, COPD, cancer and cardiovascular disease have been investigated for the presence of co-morbidity in general practice. The number of patients with these chronic conditions that have $\geq 2$ active health problems rises from $17 \%$ in the age group between 20-39 years of age to over $75 \%$ over the age of 80 years. $^{2}$ The high prevalence of multimorbidity in older patients is explained by several reasons. Firstly, the fact that the risk of developing most diseases increases progressively with age, Secondly, there is an increased emphasis on the early detection of chronic diseases in primary practice. Thirdly, the treatment of chronic diseases has improved with an increased survival of patients with chronic conditions. Fourthly, some chronic conditions share more than just age as an etiologic risk factor thus explaining the clustering of co-morbidity in certain individuals (for example diabetes and cardiovascular disease, and cancer and cardiovascular disease). Finally, the increasing total number of older people adds to the increasing overall prevalence of multimorbidity. Multimorbidity in the aging population is therefore a major health problem.

The burden of disease resulting from the combination of aging and multi-morbidity can be estimated using the frequency of visits to a physician, the number of medication used, and the number of hospital admissions. We found that the burden of disease resulting from the combination of aging and multi-morbidity to the individual and to society as a whole is considerable. Data on physician visits clearly illustrate this burden of disease. With increasing age the number of visits to the general practitioner increases. Over the age of 75 years the number of visits increases to, on average, 7 visits per person per year. The number of visits to the general practice increases, both for acute problems (on average $30 \%$ of the visits) and for chronic problems (on 
average $50 \%$ of the visits). The remainder of the visits (on average $20 \%$ ) to the general practitioner is for other reasons such as prescription renewal. The visits to the general practitioner generally result in the prescription of medication. These prescriptions comprise both repeat prescriptions and new prescriptions. Twenty percent of people over the age of 65 years take 4 or more drugs. ${ }^{3-5}$ The number of visits of older patients with diabetes to the endocrinologist had not been evaluated before. The number of visits to medical specialists we found is even higher than the number of visits to the general practitioner. We did not evaluate the number of prescriptions of medication but it seems reasonable to suppose prescriptions were written as the patients who were seen by the endocrinologist used more medication than patients seen by the general practitioner.

The number of admissions into a hospital in older patients has been evaluated in literature and this number also rises dramatically with age. These hospital admissions are mostly a result of heart disease, pneumonia, cancer and cerebro-vascular disease but there are also a great number of admissions in older patients as a consequence of falling, fractures, dehydration, sepsis and delirium. This last group of hospital admissions shows that there is a vulnerable group of older patients in whom multimorbidity and functional problems are associated with a decline in physiologic reserve and an impaired capacity of the organism to withstand stress causing an increased risk of hospitalization. These patients are usually described as "frail".

\section{Functional limitations (or disability) as a result of chronic disease and multi-morbidity and the possibility to prevent functional impairment}

In this topic we describe that the consequences of multimorbidity for the individual patient are best reflected in terms of his or her functional status. The functional status of an individual reflects the impact of the presence and severity of multimorbidity and the effect of the combination of disease and co-morbidity, all added up. Functional limitations result in the inability to perform tasks needed for activities of daily life.

An important measure of functional limitations is disability in mobility. The incidence of loss of mobility increases with age. In the community, only $5 \%$ of all persons between the ages of 65-75 are dependant on others for their mobility inside the house, but the number increases to $30 \%$ of people over the age of 85 . Women are more often affected than men. This is because women are more likely to become mobility impaired and they are less likely to recover their mobility than men. ${ }^{6}$ Reasons for this gender difference are subject of research, but no clear and simple explanation has yet been found.

Mobility problems directly affect personal independence and quality of life and mobility status can predict mortality risk. Loss of mobility in older people is therefore a very important issue for physicians, patients and care-givers. Risk factors for mobility loss at a higher age are found on several levels. Age related biomechanical changes in bone and joints, in nerve conduction, in balance and physical condition and in 
cognitive ability all play a role. Psychological factors such as fear of falling and a loss of vitality are important and so are physical inactivity and co-morbidity such as cardiovascular disease, arthritis and diabetes.

In our study both older men and women with diabetes mellitus were at increased risk of frequent falling. We looked at the factors that explained the increased risk of frequent falling to see if we could use them to prevent frequent falling in older patients with diabetes. We could not explain all of the increased risk but some of the factors we found we may be able to influence. These factors included firstly polypharmacy. This underlines the importance of a careful use of medication in older patients with diabetes and special attention to side effects and interactions of the medication prescribed. Secondly, the presence of musculoskeletal pain appeared a contributing factor to falling. Where this is based on arthritic pain it can be positively influenced by graded exercise and psychological support to overcome fear of falling. Graded exercise may not completely eliminate pain but the exercise may improve poor self perceived health and lower levels of physical activity. Training can also improve the level of muscular strength, and impaired physical performance (including gait and balance). Limitations in activities of daily life (ADL) may benefit from an improved self confidence and mobility. However, if there are physical barriers (such as severe cardiovascular disease) a program of exercise may not be feasible. Furthermore there may be other reasons why exercise will not work in an individual patient. These are reasons such as severe cognitive impairment, long standing immobility and a lack of motivation of patient and family. In that case, a fixed mobility problem is inevitable. Caregiver training may then be helpful, as well as supportive equipment such as a walking frame or a walking stick or even a wheelchair and/or environmental adaptation.

Preventive action preferably should take place before fixed functional limitations occur. All our patients with diabetes should therefore be encouraged to live an active lifestyle as long as possible. Furthermore, regular assessment of functional status in older patients with diabetes may be helpful to detect deterioration in mobility and activities of daily life in an early stage when intervention is possible.

\section{Frailty screening and possible alternative risk factors to assess older individuals at risk for negative health outcomes}

In chapter 2 on core concepts is explained that one of the focal points of geriatric medicine has always been the identification, evaluation and treatment of vulnerable older adults. The concept of frailty was developed to describe the characteristics of the vulnerable older adult in order to be able to recognize him or her. However, a clear unambiguous definition of frailty based on pathofysiology is still lacking and the concept remains difficult to operationalize. Many frailty screening instruments were developed in order to be able to distinguish between the frail and non frail older individual in research setting. In spite of the many and diverse instruments that were 
developed to distinguish between frail and non frail individuals, we still can not base individual medical decisions on the presently available scores. Before we can use frailty criteria or indeed any other predictive criterion to select vulnerable older patients, every one of the available criteria should be prospectively validated for this purpose. Until this is done, the choice of the most appropriate risk factor to predict a specific negative health outcome has to be based on the negative health outcome in question, the outcome on which the risk factor was originally validated, the quality of the validation process carried out so far, and the similarity of the current population to the validation group. Further studies on frailty as a targeting criterion to select patients who are at high risk for adverse outcomes are thus needed.

\section{Implications of the findings in this thesis for clinical practice}

\section{We need to train more medical generalists specialized in older patients with multimorbidity}

In this thesis we have shown that the growing number of older patients with multimorbidity and functional limitations will place an increasing burden on medical health care facilities. We will therefore need to train sufficient medical health professionals both in general practice and in the medical specialties with an affinity for, and expertise in, the care of multi-morbid older patients.

\section{The logistic burden of disease must be minimized for older patients with multimorbidity}

The planning of health care for patients with multimorbidity should take burden of disease into account. Physicians must consider at every major junction whether the burden to the patient of an investigation or procedure is proportional to the gained quantity or quality of life. All medical investigations and visits to out-patients clinics and general practice should ideally be coordinated and clustered to minimize the burden to the individual older patient.

\section{We need regular assessment of functional status in older patients with multimorbidity}

In this thesis we have shown that every physician caring for older people with chronic diseases will be confronted with older patients with multimorbidity. We have also shown that in the older individual with multimorbidity, an assessment of functional status is important. We propose that this assessment should take place at least once a year in the general practice. It should also be done in the hospital after an episode of illness, or at home in case of deterioration of (self) perceived health. In the presence of new functional limitations an evaluation of the problems causing the limitation can 
reveal remedial factors as well as unmet care needs. These can then be addressed. Several validated instruments are available for the purpose of a simple functional assessment. In Maastricht we developed the TRAZAG instrument for this purpose, which has subsequently been adopted in the NHG standard. ${ }^{7}$

\section{We should refrain from generalized frailty screening in community dwelling older individuals until a better definition and accurate instruments are available.}

We have shown the frailly concept and scores based on this concept are at present not useful in clinical practice. We feel however that we can manage without the concept if we use the combination of multimorbidity and regularly assessment of functional limitations to meet the care needs of our vulnerable patients.

Apart from these implications from the research presented in this thesis I feel strongly that especially the aging individual patients with one or more chronic diseases and multimorbidity and their care givers should have time to discuss the wishes of the patient regarding (medical) care in this phase of life with firstly their general practitioner and secondly any other physician concerned in their medical care. Advance directives should be known to and respected by, all medical professionals concerned.

\section{Implications for research}

\section{We need to develop evidence based guidelines for the medical care of older patients with multimorbidity}

The medical care of patients with chronic diseases is organized in accordance with disease specific guidelines. Disease specific guidelines were developed in order to standardize the care and maximize benefit of treatment to patients with chronic diseases like diabetes. These guidelines, although evidence based, were developed in studies usually excluding older patients with multiple medical conditions. The value of the results of the studies on which the guidelines are based decreases in the face of multi-morbidity. For example optimizing diabetes regulation, blood pressure and cholesterol levels in accordance with the protocol may lead to hypoglycemia, orthostatic hypotension and muscular problems in the individual older patient, thus placing him or her at an increased risk for falling and fractures. Therefore, although multimorbidity in older patient with chronic diseases is a well known problem, we still need evidence based guidelines on how to standardize the care and maximize benefit of treatment to these patients. 
2. We should investigate the clustering of chronic diseases and their relationship with functional limitations.

We do not only need to know how functional limitations are caused by (multi) morbidity, but also the best way to prevent functional deterioration in all older individuals.

3. We should pursue frailty research both on a pathophysiologic level and on a diagnostic level

More research into the physiologic basis of frailty is needed to clarify processes that contribute to the frailty phenotype. We also need further scientific work on frailty as a targeting criterion to select patients who are at high risk for adverse outcomes. 


\section{References}

1. Tacken MA, Opstelten W, Vossen I, Smeele IJ, Calsbeek H, Jacobs JE, Braspenning JC. [Increased multimorbidity in patients in general practice in the period 2003-2009]. NTvG 2011;155:A3109.

2. Fortin M, Hudon C, Haggerty J, Akker M, Almirall J. Prevalence estimates of multimorbidity: a comparative study of two sources. BMC health services research 2010;10:111.

3. Gurwitz JH. Polypharmacy: a new paradigm for quality drug therapy in the elderly? Arch Intern Med 2004;164:1957-9.

4. Kuijpers MA, van Marum RJ, Egberts AC, Jansen PA. Relationship between polypharmacy and underprescribing. Br J Clin Pharmacol 2008;65:130-3.

5. Cherry DK BC, Woodwell DA. Hyattsville, Md; National Center for Health Statistics; 2001. . National Ambulatory Medical Care Survey: 1999 Summary. Advance Data From Vital and Health Statistics 1999; National Center for Health Statistics; 2001322.

6. Leveille SG, Penninx BW, Melzer D, Izmirlian G, Guralnik JM. Sex differences in the prevalence of mobility disability in old age: the dynamics of incidence, recovery, and mortality. J Gerontol B Psychol Sci Soc Sci 2000;55:S41-50.

7. Warnier RMJ DT, Beusmans G. Complexe zorg voor ouderen, beoordelingsinstrument voor de praktijkverpleegkundige. Tijdschrift voor praktijkondersteuning 2007:50-3. 
Summary 


\section{Summary}

The main objective of this thesis was to gain insight into the complex relationship between co-morbidity, functional limitations and frailty leading to mortality in older people. The studies that have been conducted focused on three subjects:

A) The prevalence of multimorbidity in older people with diabetes mellitus and the resulting burden of disease, B) Functional impairment as a result of diabetes mellitus in older individuals and the possibility to prevent disability, and C) Frailty screening and possible alternatives to assess older individuals at risk for negative health outcomes.

Chapter $\mathbf{2}$ of this thesis describes the core concepts used in this thesis; frailty, poly or multimorbidity, and functional limitations or disability. The interrelationship of these concepts and their connection to mortality risk is presented.

In Chapter $\mathbf{3}$ is described that co-morbidity, both complicating (as a consequence of the diabetes) and concurrent (unrelated to the diabetes), occurred very frequently in the older individuals with diabetes we examined. All our patients had at least one comorbid condition and $80 \%$ had both concurrent and complicating co-morbidity.

The high numbers of co-morbid conditions we found in older people with diabetes were seen irrespective whether these patients were treated by their general practitioner, a specialist nurse or an endocrinologist.

The extent of co-morbidity unrelated to diabetes (concurrent) was similar in all three subgroups, although the severity of the unrelated co-morbidity was higher in the patients seen by the endocrinologist. The co-morbidity as a consequence of the diabetes (complicating) was higher in the group of patients managed by the endocrinologist. The patients managed by the endocrinologist used more medication, had worse metabolic control in spite of the use of insulin, had a higher mortality risk and needed more other medical specialist care. They were therefore clearly more severely ill and more complex to manage than the patients treated by the general practitioner and the specialist nurse.

Patients treated by the endocrinologist visited the hospital for specialist consultation on average once a month. The visits to the general practitioner or visits to the outpatients clinic for laboratory tests were not even included in this number of visits. Patients treated by the general practitioner and specialist nurse also showed a high use of health care facilities, although lower than the patients seen by the endocrinologist. We concluded that in all groups, the high use of health care facilities indicates a substantial burden of disease and burden of care in older patients with diabetes.

In chapter 4 we showed that older individuals with diabetes, both male and female, had a $67 \%$ higher risk of recurrent falling than individuals of the same age without diabetes. Factors partly explaining this increased risk were diabetes related polypharmacy (but not the use of any specific medication), the presence of musculoskeletal pain, a poor self perceived health and lower levels of physical activity, 
lower level of muscular strength, limitations in activities of daily life (ADL) an impaired physical performance (including gait and balance) and cognitive impairment.

We concluded that although we could explain the increased risk of recurrent falling in older patients with diabetes in part only, our findings do support the need for an active lifestyle combined with fall prevention efforts in older patients with diabetes to address some of the reversible fall risk factors we found.

In chapter $\mathbf{5}$ we described how parameters of frailty such as a higher age, a low body weight, co-morbidity and functional limitations mentioned in literature, were used to create a simple prognostic frailty score to predict mortality in community dwelling psycho-geriatric patients. We concluded that although the predictive value of our score is very reasonable for discrimination of mortality risk in a group of psychogeriatric patients the results are not good enough to base major medical decisions on the outcome of the score in an individual patient.

In chapter $\mathbf{6}$ we looked at the frailty concept as a whole and at several selected frailty scores derived from models of frailty based on theoretical views of frailty. We concluded that the frailty concept is a difficult one, as it is based on a composite of different and debatable markers and not on a clinical condition that fulfills the criteria for effective screening. We felt that the instruments presently available are not suited for the purpose of differentiating between the frail individual and the non-frail; therefore we proposed not to make use of the concept in daily practice but to reserve the use for research purposes only.

Chapter 7 provides a general discussion of the results of the individual studies in this thesis placed in a broader perspective. Three topics are discussed: firstly the prevalence of chronic disease and multimorbidity in older people and the resulting burden of disease; secondly functional impairment as a result of chronic disease and multi-morbidity and the possibility to prevent disability; and finally frailty screening and possible alternatives to assess older individuals at risk for negative health outcomes. In addition implications for clinical practice and research are discussed.

Continued research in older individuals is needed A) to develop evidence based guidelines for the treatment of multimorbidity and functional limitations tailored to the individual older patient and B) to clarify the physiologic basis of frailty and on frailty as a targeting criterion to select patients who are at high risk for adverse outcomes. 
Samenvatting 


\section{Samenvatting}

In dit proefschrift wordt onderzoek beschreven naar de complexe relatie tussen comorbiditeit, functionele beperkingen en frailty. De relatie van deze aan veroudering gerelateerde processen met het sterfte risico bij oudere mensen is onderzocht. De studies die zijn gedaan waren gericht op 3 onderwerpen:

a. het voorkomen van multi-morbiditeit bij oudere mensen met diabetes mellitus en de gevolgen hiervan voor de ziektelast die deze mensen ervaren;

b. functionele beperkingen als gevolg van diabetes mellitus bij oudere mensen en de mogelijkheid om handicaps te voorkomen, en

c. screenen op frailty en eventuele alternatieve procedures om oudere mensen met risico op gezondheidsproblemen vroeg te identificeren.

Hoofdstuk 2 van dit proefschrift beschrijft de begrippen waar het in dit proefschrift om gaat: frailty, poly- of multi-morbiditeit en functionele beperkingen en handicaps. De onderlinge relatie van deze begrippen en het verband met sterfte risico wordt gepresenteerd.

Hoofdstuk 3 gaat over het voorkomen van comorbiditeit bij oudere patiënten met diabetes mellitus. De comorbiditeit werd verdeeld in complicerend (als gevolg van de diabetes) en concurrent (niet gerelateerd aan de diabetes mellitus). De oudere diabetes patiënten werden in drie groepen verdeeld, gebaseerd op de hoofdbehandelaar (huisarts, verpleegkundig specialist of endocrinoloog). Alle onderzochte patiënten hadden minstens één comorbide aandoening en $80 \%$ van hen had zowel complicerende als concurrente comorbiditeit. Deze hoge aantallen comorbide aandoeningen werden gevonden in alle drie groepen patiënten ongeacht de aard van de hoofdbehandelaar. De hoeveelheid concurrente aandoeningen was gelijk in de drie subgroepen, hoewel de ernst van deze niet diabetes gerelateerde aandoeningen hoger was bij patiënten gezien door de endocrinoloog. De hoeveelheid complicerende comorbiditeit bij de diabetes mellitus was beduidend hoger in de groep patiënten behandeld door de endocrinoloog. Deze laatste groep patiënten gebruikte meer medicatie, zij waren minder goed ingesteld ondanks gebruik van insuline, en zij hadden een hoger sterfte risico en gebruik van medisch specialistische zorg. De zorg voor de patiënten van de endocrinoloog was complexer dan de zorg voor de patiënten van de huisarts en de verpleegkundige specialist.

De patiënten van de endocrinoloog bezochten de polikliniek van het ziekenhuis gemiddeld eens per maand. Het aantal bezoeken aan de huisarts of de prikdienst voor bloedonderzoek zijn niet meegeteld in deze aantallen. De patiënten van de huisarts en de verpleegkundige specialist bezochten hun behandelaar ook frequent echter minder vaak dan de patiënten van de endocrinoloog.

We concludeerden dan ook dat in alle drie onderzochte groepen oudere patiënten met diabetes mellitus de zorgzwaarte en ziektelast aanzienlijk waren. 
Hoofdstuk 4 betreft een studie in een patiëntencohort van de Longitudinal Aging Study Amsterdam naar het valrisico bij patiënten met diabetes mellitus. Het blijkt dat oudere patiënten met diabetes mellitus, zowel mannen als vrouwen, een $67 \%$ hoger risico lopen op herhaald vallen dan hun leeftijdsgenoten zonder diabetes mellitus. Het hogere risico op herhaald vallen werd deels verklaard op basis van diabetes gerelateerde polyfarmacie (maar niet door het gebruik van specifieke medicamenten), de aanwezigheid van pijn in het bewegingsapparaat, een (ervaren) slechte gezondheid en minder fysieke activiteit, verminderde spierkracht, beperkingen in activiteiten van het dagelijks leven ( $A D L$ ), een beperkt fysiek functioneren (onder andere gestoorde gang en balans) en cognitieve stoornissen. We stelden vast dat we met deze risicofactoren slechts een deel van het verhoogde valrisico bij oudere patiënten met diabetes mellitus kunnen verklaren. Onze bevindingen geven echter wel aan dat een actieve levensstijl en valpreventie een onderdeel van de behandeling van alle oudere patiënten met diabetes mellitus zouden moeten zijn.

In hoofdstuk 5 wordt beschreven hoe parameters van frailty zoals ze worden beschreven in de literatuur gebruikt kunnen worden om een simpele prognostische frailty score te ontwerpen. Met behulp van deze score kan het sterfte risico bij thuiswonende psychogeriatrische patiënten worden voorspeld. De score liet een heel redelijke voorspellende waarde zien voor het sterfte risico in deze groep kwetsbare patiënten. Het resultaat was echter niet dusdanig dat belangrijke medische beslissingen voor individuele patiënten kunnen worden genomen op basis van deze score.

Hoofdstuk 6 beschrijft het concept frailty in zijn geheel. Diverse frailty scores op basis van de gangbare theorieën over het ontstaan van frailty werden geanalyseerd en vergeleken. Onze conclusie was, dat frailty een moeilijk te operationaliseren concept is. Dit komt omdat het begrip frailty niet is gebaseerd op een klinische diagnose. Het frailty concept is gebaseerd op een complexe verzameling van heel diverse kenmerken die allemaal stuk voor stuk niet onomstreden zijn. Het frailty concept voldoet dan ook niet aan de criteria voor effectieve screening. De huidige frailty scores zijn niet geschikt voor het maken van het onderscheid tussen "frail" en "niet-frail" in individuele patiënten. We stellen dan ook voor om het frailty concept niet te gebruiken in de dagelijkse praktijk maar het te reserveren voor onderzoeksdoeleinden.

Hoofdstuk 7 omvat een algemene discussie waarbij de resultaten van individuele onderzoeken in dit proefschrift in een breder perspectief worden geplaatst. De drie onderwerpen van dit proefschrift worden besproken.

Tot slot worden klinische implicaties en mogelijkheden voor toekomstig onderzoek besproken. We concluderen dat nader onderzoek nodig is om richtlijnen op te kunnen stellen voor de behandeling van multi-morbiditeit en functionele beperkingen bij individuele oudere patiënten. De fysiologische basis van frailty verdient nader onderzoek net als de aanwezigheid van frailty als risicofactor voor diverse uitkomstmaten, zoals mortaliteit, ziekenhuisopname, vallen, fracturen, et cetera. 
Dankwoord 


\section{Dankwoord}

Ter afsluiting mijn woorden van dank aan allen die een bijdrage hebben geleverd aan het tot stand komen van dit proefschrift. Mijn dank gaat allereerst uit naar al degenen die belangeloos deelnamen aan het onderzoek beschreven in dit proefschrift. Zij vulden indertijd vragenlijsten in, stonden bloed af en werden telefonisch vervolgd. Het onderzoek had ook niet gedaan kunnen worden zonder de medewerking van het team van het diagnostisch observatiecentrum psycho-geriatrie (DOC-PG) en de data van de Longitudinal Ageing Study Amsterdam (LASA).

Ik had geen beter promotieteam kunnen wensen dan Prof. dr. A.C. Nieuwenhuijzen Kruseman, Prof. dr. C.D.A. Stehouwer en Dr. I. Ferreira.

Prof. dr. A.C. Nieuwenhuijzen Kruseman. Beste Arie, je hebt me indertijd aangenomen in de opleiding voor de interne geneeskunde en je hebt me gedurende mijn opleiding en vervolgens gedurende mijn promotietraject bemoedigd en gesteund. Naast je andere drukke werkzaamheden vond je altijd de tijd om mijn schrijfsels snel te lezen en van scherpzinnig commentaar te voorzien. De ouderengeneeskunde in Maastricht mag zich gelukkig prijzen met je warme belangstelling. Onze discussies over de wijdere wereld hebben me geïnspireerd en ze waren naast gezellig ook altijd leerzaam.

Prof. dr. C.D.A. Stehouwer. Beste Coen, ik bewonder je nauwgezetheid en je gedrevenheid. (zowel klinisch als wetenschappelijk) Je ziet naast de grote lijnen ook alle details en je weet feilloos aan te wijzen waar een argument geen hout snijdt. Je reactietijd is net zo fenomenaal als die van Arie en ik waardeer je gevoel voor humor. Zonder jouw advies was de link naar de LASA studie waarschijnlijk niet zo snel gelegd.

Dr. I. Ferreira. Beste Isabel, jij bent mijn enthousiaste epidemiologische steun en toeverlaat geweest gedurende het gehele traject. Je hebt al je didactische vaardigheden nodig gehad om mij (een onverbeterlijk wit-jasje) over de woeste epidemiologische wateren te leiden maar het is je gelukt. Je vond daarnaast ook nog tijd voor de zorgvuldige beoordeling van, en kritische input in alle artikelen die we hebben geschreven. Zonder jouw hulp en vertrouwen in de goede afloop lag dit boekje hier nu niet.

Dit promotietraject is het resultaat van het zoeken naar simpele antwoorden op complexe vragen die opkwamen naar aanleiding van mijn werkzaamheden binnen de interne geneeskunde en de klinische geriatrie. Veel dank ben ik verschuldigd aan allen die bijdroegen aan de zoektocht en de antwoorden die ik vond.

Een aantal mensen wil ik graag speciaal noemen; 
Dr. W.J. Mulder. Beste Wubbo, van supervisor tot collega en van reisgenoot naar adviseur persoonlijke mobiliteit. We trekken al heel lang met elkaar op. Ik bewonder je praktisch instelling, je bent van alle markten thuis en zelden van je stuk gebracht. Dit zijn eigenschappen die ik waardeer zowel in het dagelijks leven als in de kliniek.

Dr. A. Kroon, Beste Bram, laagdrempelig bereikbaar voor overleg, met waardevolle input zowel voor het denk als schrijfwerk, hartelijk dank voor je hulp.

Maria Sinnema, Ron Warnier, en Tanja Martens jullie zijn veelzijdig werkzaam voor de ouderengeneeskunde binnen en buiten het AZM. Zonder jullie was er geen stabiele ouderengeneeskunde service, ik werk graag met jullie samen en ben blij op jullie te kunnen rekenen.

Kim Hurkens, Machiel Smit, Sandro Waterloo, Loes Driessen en Heidrun Pavlowski, collegae en toekomstige collegae interne/ouderengeneeskunde samen leren we nog elke dag van onze patiënten.

Roel v.d. Laar en Bas van Bussel, paranimfen, enthousiaste onderzoekers en leuke toekomstige collegae, het is met jullie begonnen en we eindigen nu ongeveer gelijkertijd. Proficiat en dank!

Tiny Wouters, zonder jouw hulp kwamen er geen leesbare proefschriften tot stand. Je bent de spil van de promotie activiteit van de interne geneeskunde en dus onmisbaar.

Marleen Rosbak, organisator, baken in de wereld van papier en financiën en gezellige lunchpartner we moeten nog eens samen naar beeldende kunst gaan kijken.

Het gehele secretariaat, en vooral Lilian Dassen en Monique Lahaye, dames hartelijk dank voor jullie geduld en het ondersteunen van alles wat we goed geregeld willen hebben.

Gerrit Schrey, Riquette Hulsewe, Eugenie vd Ham, Thomas Wierema, Guy Mostard, Jos vd Kerkhof, Eva Roebroeks en Patricia Stassen, geduldige en gezellige kamergenoten, allemaal hebben jullie de diverse ups en downs gedurende het onderzoek meegemaakt en commentaar en kritiek geleverd waar ik mijn voordeel mee kon doen. Ronald Henry en Roger Renneberg, we superviseren gezamenlijk B5 en het onderling overleg is naast stimulerend ook heel prettig.

Verder dank aan alle collegae (en ex collegae) van de interne geneeskunde, maagdarm-leverziekten en reumatologie zonder wie er geen afdeling zou zijn die het werk de moeite waard maakt. 
Dank aan alle collegae huisartsen in Maastricht en directe omgeving voor een prettige samenwerking (speciaal George Wolfs voor bijna wekelijks overleg en Joke Koopmans, Hub Peeters en Sjef Swaans voor gezellige onderwijs-momenten polifarmacie).

De leden van de leescommissie; Prof dr N.C. Schaper, Prof dr F Verhey, Prof dr G.I.J.M. Kempen, Dr S.E.J.A. de Rooij, internist-ouderengeneeskunde en last but not least als voorzitter en tevens lid van de beoordelingscommissie Prof $\mathrm{dr}$ J.M.G.A. Schols, hartelijk dank voor de inhoudelijke beoordeling van mijn manuscript.

De ouderen geneeskunde mag rekenen op vele sterke medewerkers binnen het DOCPG, het MDGO, en op de verpleegafdeling algemeen interne geneeskunde. De afdeling B5 is de veilige haven voor de oudere patiënt. Hier wordt onder bezielende leiding van Gertie Brepoels gestreefd naar kwalitatief hoog staande patiëntenzorg onder soms moeilijke omstandigheden. Ik werk graag met jullie samen en ben ik ben trots op ons team.

Lieve moeder, (en in herinnering vader, zus, oom en tante) broer, schoonzus, Tomas en Laura en vrienden, heel veel dank voor jullie belangstelling en het geduld dat jullie opbrachten met betrekking tot dit "project". In het bijzonder moeder en (in herinnering vader) voor jullie niet aflatende geloof dat het allemaal wel goed zou komen. 
Curriculum vitae 


\section{Curriculum vitae}

De auteur van dit proefschrift werd geboren in Amsterdam, maar verhuisde al spoedig naar Nijmegen. Na de lagere school behaalde zij het diploma atheneum aan de Nijmeegse scholengemeenschap. In afwachting van de studie geneeskunde studeerde zij in eerste instantie af als logopediste aan de Opleiding Logopedie en Akoepedie te Nijmegen. Vervolgens studeerde zij Geneeskunde aan wat toen nog de Katholieke Universiteit Nijmegen heette. Het artsexamen werd afgelegd in 1990.

$\mathrm{Na}$ een periode als AGNIO Hematologie, Interne Geneeskunde en Oncologie werd de specialisatie interne geneeskunde begonnen in het academisch ziekenhuis Maastricht (opleiders achtereenvolgens Prof. dr. J.A. Flendrig, Prof. dr. A.C. Nieuwenhuijzen Kruseman en Prof. dr. H.F.P. Hillen) Op 1 mei 1998 vond de registratie tot internist plaats. Vervolgens werd zij voor een jaar aangesteld als Fellow Clinical geratology, aan de afdeling Clinical Geratology, van het Nuffield dept. Clinical Medicine, in Oxford, Engeland, onder de bezielende leiding van Prof. dr. Sir John Grimley Evans. Na deze periode van een jaar volgde een half jaar klinische geriatrie in het Eemlandziekenhuis te Amersfoort en een half jaar geronto-psychiatrie en psychogeriatrie in het Psychomedisch Centrum Parnassia, te Den Haag. Hierna volgde in 2000 de registratie tot Klinisch Geriater.

Op 1 juni 2000 werd zij in het azM aangesteld als staflid in vaste dienst bij de afdeling Interne Geneeskunde (hoofd Prof. dr. H.F.P. Hillen) in de werkgroep Algemeen Interne Geneeskunde. Binnen deze werkgroep is haar aandachtsgebied de geriatrie of, zo $U$ wilt, de ouderengeneeskunde. 